ESCOLA DE ENFERMAGEM DA

UNIVERSIDADE DE SÃO PAULO

PATRICIA SANCHES SALLES

MATERIAIS ESCRITOS IMPRESSOS DE ORIENTAÇÃO EM ENFERMAGEM: REVISÃO INTEGRATIVA. 


\section{MATERIAIS ESCRITOS IMPRESSOS DE ORIENTAÇÃO EM ENFERMAGEM: REVISÃO INTEGRATIVA.}

Dissertação apresentada à Escola de Enfermagem da Universidade de São Paulo, para obtenção do título de Mestre em Enfermagem.

Versão corrigida

Área de concentração:

PROESA - Programa de Pós-Graduação em Enfermagem na Saúde do Adulto

Orientadora:

Prof. ${ }^{a}$ Dr. ${ }^{\text {a }}$ Maria Júlia Paes da Silva 
AUTORIZO A REPRODUÇÃO E DIVULGAÇÃO TOTAL OU PARCIAL DESTE TRABALHO, POR QUALQUER MEIO CONVENCIONAL OU ELETRÔNICO, PARA FINS DE ESTUDO E PESQUISA, DESDE QUE CITADA A FONTE.

Assinatura:

Data:

Salles, Patricia Sanches

Materiais escritos impressos de orientação em enfermagem: revisão integrativa / Patricia Sanches Salles. - São Paulo, 2012.

$121 \mathrm{p}$.

Dissertação (Mestrado) - Escola de Enfermagem da Universidade de São Paulo.

Orientadora: Prof. ${ }^{\text {a }}$ Dr. ${ }^{\text {a }}$ Maria Júlia Paes da Silva

Área de concentração: Enfermagem na saúde do adulto

1. Material didático 2. Manuais 3. Comunicação em enfermagem I. Título. 
NOME: PATRICIA SANCHES SALLES

TÍTULO: MATERIAIS ESCRITOS IMPRESSOS DE ORIENTAÇÃO EM ENFERMAGEM: REVISÃO INTEGRATIVA.

Dissertação apresentada à Escola de Enfermagem da Universidade de São Paulo para obtenção do título de mestre.

Área: PROESA - Programa de PósGraduação em Enfermagem na Saúde do Adulto

Aprovado em: Instituição:

Prof. Dr. Assinatura:

Julgamento: Instituição:

Prof. Dr. Assinatura:

Julgamento: Instituição:

Prof. Dr. Assinatura:

Julgamento: Assinatura: 


\section{DEDICATÓRIA}

Dedico este estudo

Aos pacientes, por me inspirarem este trabalho e também me ensinarem sobre a vida.

À minha mãe, pelo incentivo desde criança aos estudos e por seu exemplo de força e coragem!

Ao meu pai, que com a sua luz e seu amor renova as minhas esperanças.

À minha família, que vibra com cada conquista, especialmente aos meus padrinhos Adauto e Cynthia.

À professora Maria Júlia, que com sua sensibilidade e pensamento crítico é mestra com muita dedicação, amor e respeito. 


\section{AGRADECIMENTTOS}

Aos meus queridos amigos da enfermagem, companheiros de trabalho do ICESP (Instituto do Câncer do Estado de São Paulo), por compreenderem minhas ausências durante esse estudo.

Ao Daniel, pelo companheirismo, disponibilidade e atenção sempre presentes.

À Escola de Enfermagem da Vniversidade de São Paulo e seus funcionários, pela atenção e disponibilidade.

Às minhas amigas, por acreditarem, incentivarem e apoiarem sempre.

À CAPES, pelo apoio financeiro por meio de concessão de uma bolsa de estudos. 


\section{EPÍGRAFE}

Estamos unidos a Deus na relação estreita que liga a causa ao efeito, e somos tão necessários à sua existência quanto ele é necessário à nossa. Deus, Espírito Universal, manifesta-se na natureza, e o homem é na Terra a mais elevada expressão da natureza. Somos a obra e a expressão de Deus, que é a fonte do bem. Mas esse bem nós o possuímos somente em estado de gérmen, e nossa tarefa é de desenvolvê-lo. (...) A obra que a cada um de nós cabe realizar resume-se em três palavras: saber, crer, querer; quer dizer: saber que temos em nós recursos incalculáveis (...)

Léon Denis (1846-1927) filósofo francês espírita

O Grande Enigma: Deus e o Universo 
Salles PS. Materiais escritos impressos de orientação em Enfermagem: revisão integrativa [dissertação]. São Paulo: Escola de Enfermagem, Universidade de São Paulo; 2012.

\section{RESUMO}

Estudo de revisão integrativa da literatura científica com a finalidade de identificar e analisar as características da comunicação dos materiais escritos impressos elaborado por enfermeiros brasileiros, que subsidiam as orientações em Enfermagem, baseado em 22 artigos nacionais selecionados no Portal BVS (Biblioteca Virtual em Saúde) e BVS temática em Enfermagem, sem limite de período, a partir de descritores previamente definidos e palavras-chave, visto o baixo número encontrado só com descritores (quatro artigos). A análise dos estudos apontou que quanto aos objetivos, o de maior frequência foi relatar o processo de elaboração do material, 7 (32,0\%). Quanto aos delineamentos de pesquisa, identificamos que $11(50,0 \%)$ são estudos qualitativos, quando o público alvo são os pacientes, $11(79,0 \%)$ artigos são destinados aos adultos e quando destinados aos acompanhantes, $6(43,0 \%)$ são direcionados para acompanhantes de neonatos. Com relação à especialidade para qual o material se destina se destacam: neonatologia e oncologia, representando 4 (18,0\%) cada uma delas. Quanto ao local onde o material escrito é utilizado destacam-se os hospitais e ambulatórios, com $9(41,0 \%)$ cada um deles. Em relação ao nome utilizado para o material escrito, o mais frequente foi cartilha, com 6 (27,0\%). Observou-se que $15(68,0 \%)$ dos estudos apresentavam preocupação com a elaboração do material escrito, sendo que o aspecto relevante mais citado foi conteúdo, com 12 (26,0\%). Em 10 (45,0\%) artigos houve avaliação do material escrito, sendo em 8 realizada por pacientes e em 2 por profissionais. Pelos números e resultados apresentados concluímos que o tema materiais escritos impressos de orientação em enfermagem é pouco estudado e que a enfermagem precisa desenvolver pesquisas cientificas em relação ao tema. Os resultados apontam uma grande variedade e pouco consenso entre os autores quanto à terminologia usada para o material escrito impresso de orientação. Conclui-se ainda que haja questões a serem respondidas no processo de avaliação dos materiais, no que se refere à periodicidade dessa avaliação.

Descritores: material didático, manuais, comunicação em enfermagem. 
Salles PS. Written materials printed in Nursing orientation: an integrative review [dissertation]. São Paulo: Escola de Enfermagem, Universidade de São Paulo; 2012.

\begin{abstract}
Study integrative review of the scientific literature in order to identify and analyze the characteristics of printed communication of written materials prepared by Brazilian nurses who subsidize Nursing guidelines based on 22 national articles on selected Portal VHL (Virtual Health Library) and VHL theme in Nursing, unlimited period, from previously defined descriptors and keywords, since the low number found only with descriptors ( 4 items). The studies showed that the aims, the most frequent was to report the process of preparing the material 7 (32,0\%). Regarding research designs, we identified $11(50,0 \%)$ are qualitative studies, when the target audience are the patients, $11(79,0 \%)$ articles are intended for adults and when intended for caregivers, $6(43,0 \%)$ are targeted for companions neonates. Regarding the art to which the material is intended as: oncology and neonatal, representing four $(18,0 \%)$ each. As to where the written material is used to highlight the hospitals and clinics, with $9(41,0 \%)$ each. Regarding the name used for the written material, the most frequent was primer, with $6(27,0 \%)$. It was observed that $15(68,0 \%)$ of the studies were concerned with the preparation of written material, and the most important aspect was quoted content, with $12(26,0 \%)$. In $10(45,0 \%)$ articles were written evaluation of the material being performed in 8 patients and in 2 by professionals. By the numbers and conclude that the results presented written materials printed issue guidance in nursing is understudied and that nursing needs to develop scientific research on the topic. The results show a wide variety and little consensus among authors as to the terminology used for printed material written guidance. It is concluded that there are still questions to be answered in the evaluation of materials, with regard to the periodicity of the evaluation.
\end{abstract}

Descriptors: educational material, manuals, nursing communication. 


\section{LISTA DE ILUSTRAÇÕES}

Figura 1 - Arco de Maguerez (apud BORDENAVE; PEREIRA, 2008).

Figura 2 - $\quad$ Amostragem da revisão integrativa. São Paulo. 2012. 


\section{LISTA DE TABELAS}

Tabela 1 - Total de artigos encontrados por descritores no portal BVS. 2011

Tabela 2 - Total de artigos encontrados por palavras chaves/unitermos no portal BVS. 2011

Tabela 3 - Total de artigos encontrados por descritores no portal BVS Enfermagem. 2012

Tabela 4 - Total de artigos encontrados por palavras chaves/unitermos no portal BVS Enfermagem. 2012

Tabela 5 - Estudos selecionados de acordo com as revistas de publicação, frequência e percentuais. 2012

Tabela 6 - Estudos selecionados de acordo com os objetivos dos artigos frequência e percentuais. 2012

Tabela 7 - Distribuição das publicações, localizadas segundo público alvo pacientes, frequência e percentuais. 2012

Tabela 8 - Distribuição das publicações, localizadas segundo público alvo acompanhantes, frequência e percentuais. 2012

Tabela 9 - Distribuição dos artigos, localizadas segundo a especialidade, frequência e percentuais. 2012

Tabela 10 - Distribuição dos artigos, localizadas segundo o nome utilizado para o material escrito, frequência e percentuais. 2012 


\section{LISTA DE QUADROS}

Quadro 1 - Descrição da estratégia PICO para elaboração da pergunta de pesquisa.

Quadro 1 - Publicações agrupadas quanto ao número do estudo, título, periódico, autoria, ano, delineamento de pesquisa e base de dados.

Quadro 3 - Aspectos de Linguagem, Ilustração e Layout que devem ser considerados na elaboração do material educativo em saúde. 


\section{SUMÁRIO}

\section{RESUMO}

\section{APRESENTAÇÃO}

1. INTRODUÇÃO

2. OBJETIVOS 24

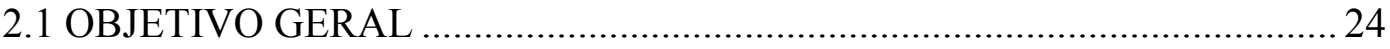

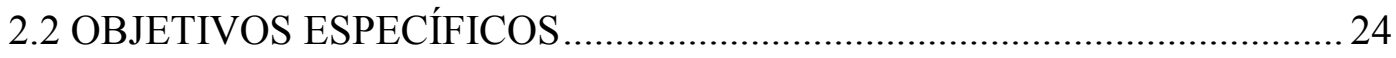

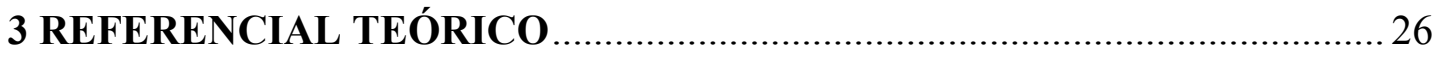

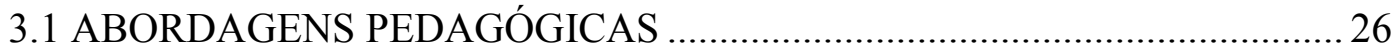

3.2 COMUNICAÇÃO INTERPESSOAL E ENFERMAGEM ............................ 34

3.3 ELABORAÇÃO DE MATERIAL EDUCATIVO ESCRITO IMPRESSO .... 39

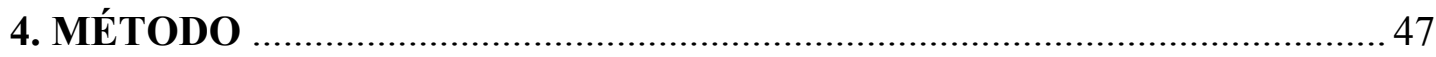

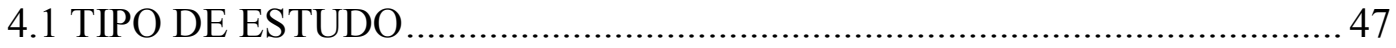

4.2 PROCEDIMENTOS DE COLETA DE DADOS …........................................ 48

4.2.1 Questão norteadora da revisão integrativa...................................... 51

4.2.2 Procedimentos adotados para a busca e seleção dos artigos ............... 52

4.3 AMOSTRAGEM DO ESTUDO................................................................. 55

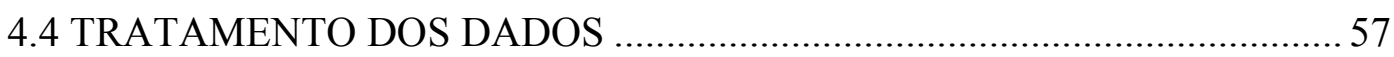

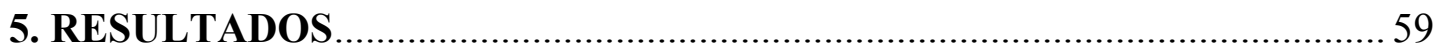

5.1 CARACTERIZAÇÃO DOS ESTUDOS SELECIONADOS …....................... 68

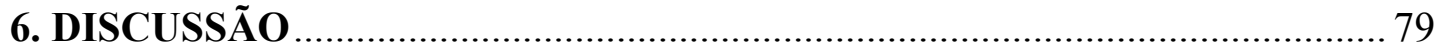

7 CONCLUSÕES E CONSIDERAÇÕES FINAIS .......................................... 107

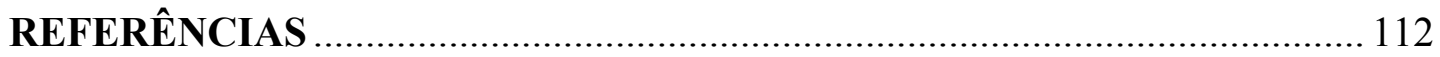

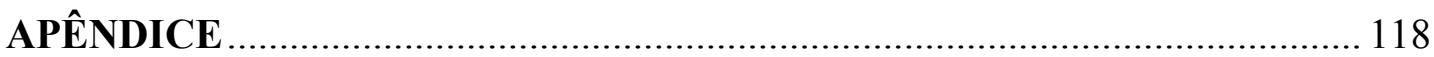




\section{APRESENTAÇÃO}

Ser enfermeira não foi a minha primeira escolha, pois desde criança sonhava ser veterinária, porém, por motivos financeiros, tive que optar por uma segunda profissão. Na minha família, não havia nenhum profissional da saúde e nunca tinha vivenciado a experiência de cuidar de alguém doente. Mesmo sem nenhuma influência, decidi que ingressaria no curso de Enfermagem. Já na faculdade, o tempo passava e a cada semestre ficava mais interessada e empolgada com os novos conhecimentos e me perguntava: Como não pensei em ser enfermeira antes?

Durante a graduação, tive meu primeiro contato com a oncologia, quando realizei, por quase dois anos, o estágio extracurricular em um hospital público localizado no interior do estado de São Paulo, que atendia as especialidades de oncologia e infectologia. Os pacientes da oncologia eram atendidos em um ambulatório, onde eram realizadas as consultas médicas e aplicação de quimioterapia e, quando necessário, eram encaminhados para unidade de internação para tratamento e suporte clínico.

Nesse período, percebi que, mesmo com as orientações dos profissionais de saúde, os pacientes e familiares apresentavam dificuldades para compreender a doença, os procedimentos e o manejo dos efeitos colaterais relacionados ao tratamento, uma vez que após a aplicação da quimioterapia os pacientes eram liberados para irem para casa. Questionava-me quais eram os fatores que influenciavam a não compreensão da mensagem. Seria por estarem ainda abalados com o diagnóstico? Seria uma dificuldade decorrente de um possível baixo grau de escolaridade? Ou a maneira que a mensagem era enviada precisaria ser reformulada?

Ficava muito envolvida com toda essa situação e, por conta disso, comecei a pensar de que maneira poderia auxiliá-los. Pensei que um material escrito poderia ser levado para casa e lido junto com a família em um momento que todos estivessem mais tranquilos. Comecei então uma busca na internet por materiais de orientação de outras instituições, mas não desenvolvi nenhum de autoria própria nessa época.

Costumo dizer que fui escolhida pela oncologia, uma vez que já como enfermeira iniciei meu trabalho em um instituto de clínicas pediátricas, no interior de São Paulo, que atende crianças e adolescentes com doenças oncológicas e hematológicas. Nesse instituto, o diagnóstico mais comum é o da Leucemia Linfóide 
Aguda (LLA), cuja perspectiva de cura é de 80,0\%, considerando-se também que o prognóstico do paciente está relacionado ao diagnóstico precoce e início imediato do tratamento. No momento inicial do tratamento, na fase da indução, a frequência média de cada paciente por semana é muito alta, sendo que na maioria das vezes comparecerem todos os dias no hospital.

É dentro desse contexto que os pais e as crianças, ao mesmo tempo em que recebiam o diagnóstico, já precisavam começar a enfrentar o tratamento. No momento das orientações com a Enfermagem, tais como os efeitos colaterais da quimioterapia, cuidados domiciliares com o paciente, alimentação etc., percebíamos que os cuidadores ainda estavam sob o impacto do diagnóstico de câncer, não conseguindo assim assimilar de maneira eficiente as informações/orientações dadas. Cada família apresentava comportamentos diferentes e reagia individualmente à situação, entretanto, todas estavam diante da mesma enfermidade e precisavam enfrentá-la.

Diante disso, elaborei uma cartilha de orientações que subsidiasse as informações verbais dos profissionais da saúde e como trabalho de monografia do curso de especialização em oncologia, validei junto aos pais esse material, que obteve um resultado positivo. Na realização desse trabalho, percebi a escassez de publicações sobre o tema na literatura nacional.

Em 2007, comecei a trabalhar como enfermeira assistencial no Hospital das Clínicas - SP, local que atendia pacientes onco-hematológicos. A realidade encontrada era muito parecida com a minha experiência anterior, porém, os enfermeiros tinham como instrumento de orientação um manual do paciente, elaborado pelo médico e enfermeiro coordenador do local há alguns anos. Ainda investigando sobre o tema na literatura percebi que a maioria dos materiais de orientação era elaborada de acordo com as experiências dos profissionais.

Atualmente trabalho no ambulatório de hematologia do Instituto do Câncer do Estado de São Paulo (ICESP) e sou membro da comissão de elaboração de manuais para familiares e pacientes do hospital. Em meu trabalho diário, tenho contato direto com os pacientes em tratamento quimioterápico e essa aproximação reforçou a importância da orientação do enfermeiro, e com as experiências profissionais anteriores, me incentivou a continuar estudando, agora no mestrado, os materiais impressos de orientação. 
1 INTRODUÇÃO 


\section{INTRODUÇÃO}

A Enfermagem profissional no mundo foi erigida a partir das bases científicas propostas por Florence Nightingale, que é considerada a fundadora da Enfermagem moderna, obtendo maior projeção a partir de sua participação como voluntária na Guerra da Crimeia, em 1854, quando auxiliada por 38 mulheres (irmãs anglicanas e católicas) organizou um hospital de 4000 soldados internos, baixando a mortalidade local de $40,0 \%$ para $2,0 \%$. Com o prêmio recebido do governo inglês por esse trabalho, fundou a primeira escola de Enfermagem no Hospital St. Thomas Londres, em 24/06/1860 ${ }^{(1)}$.

Como profissão, a Enfermagem tem buscado sua afirmação por meio da atuação efetiva, baseada em conhecimentos científicos, exercendo funções que estão muito além da realização de procedimentos técnicos. Neste sentido, a formação do enfermeiro proporciona conhecimentos e habilidades para uma atuação profissional abrangente dentro do Sistema de Saúde, desde a promoção até a reintegração dos indivíduos à sociedade.

A educação em saúde é um importante instrumento utilizado na atuação do profissional enfermeiro, é uma chave para a transformação nos hábitos do indivíduo e para a compreensão do que está acontecendo com a sua saúde. Dessa forma a adesão ao tratamento aumenta, pois ela promove mudanças na forma de sentir, pensar e atuar das pessoas em relação a si mesmas. O paciente deixa o papel de sujeito passivo e passa a interagir com a equipe indicando como ele pode colaborar com o seu restabelecimento ${ }^{(2)}$.

A equipe de Enfermagem tem características que facilitam exercer seu papel de educadora junto ao paciente: são os profissionais que mais tempo permanecem ao seu lado e têm a capacidade de observá-lo e considerá-lo como um todo e não apenas como um caso $^{(3)}$, identificando seus pensamentos, desejos, necessidades e forma de expressão.

Um dos instrumentos utilizados nesse papel de educador é o material escrito impresso, que pode ser apresentado em forma de cartilhas, folder, manuais, etc. Parece, porém, que a utilização de tecnologias criadas pelos próprios enfermeiros 
como instrumentos que auxiliam o seu trabalho são pouco divulgadas, e as publicações em periódicos de Enfermagem sobre essa temática ainda são escassas.

Entende-se tecnologia como um processo que envolve diferentes dimensões, do qual resulta um produto, que pode ser um bem durável, uma teoria, um novo modo de fazer algo, bens ou produtos simbólicos. A tecnologia não pode ser vista apenas como algo concreto, como um produto palpável, mas como resultado de um trabalho que envolve um conjunto de ações abstratas ou concretas que apresentam uma finalidade; nesse caso específico, o cuidado em saúde. A tecnologia, portanto, permeia o processo de trabalho em saúde, contribuindo na construção do saber (e em sua própria expressão); ela se apresenta desde o momento da ideia inicial, da elaboração e da implementação do conhecimento, até tornar-se resultado dessa mesma construção ${ }^{(4)}$.

Pensando sobre esse conceito, os materiais escritos surgem como uma modalidade de tecnologia que auxilia o trabalho do profissional enfermeiro. Dispor de um material educativo escrito facilita e uniformiza as orientações a serem realizadas, com vistas ao cuidado em saúde. É uma forma de ajudar os indivíduos no sentido de melhor entender o processo saúde-doença e trilhar os caminhos da recuperação ${ }^{(5)}$.

O uso crescente de materiais educativos como um dos recursos na educação em saúde abre novas possibilidades no processo de ensino-aprendizagem por meio de interações mediadas pelo locutor (enfermeiro), paciente e família (leitor) e o material educativo escrito (objeto do discurso), trazendo desafios e exigindo definições claras dos objetivos educacionais a serem atingidos pelo público-alvo ${ }^{(6)}$.

Os materiais educativos, além de facilitarem a mediação de conteúdos de aprendizagem, funcionam como recurso prontamente disponível para que o paciente e sua família possam consultá-lo quando diante de dúvidas no desenvolvimento do cuidado. Um momento que devemos considerar a importância do material escrito impresso é o momento de diagnóstico, pois fica difícil aceitar a doença e ao mesmo tempo assimilar tantas novas informações que serão importantes para uma melhor qualidade de vida. Sabemos que os pacientes e cuidadores ainda estão sob o impacto do diagnóstico, não conseguindo muitas vezes assimilar de maneira eficiente as informações/orientações dadas.

$\mathrm{Na}$ instituição de saúde, é um recurso instrucional usado pelo enfermeiro; no 
domicílio, é uma ferramenta de auxílio tanto para o paciente como para o cuidador ${ }^{(6)}$. Um estudo de delineamento quase-experimental de natureza qualiquantitativa avaliou o efeito de ação educativa sobre o conhecimento de familiares de crianças a respeito de queimaduras em ambiente doméstico. Participaram 40 familiares de crianças menores de quatro anos, divididos igualmente em grupos intervenção e controle. Foram realizadas entrevistas iniciais, ação educativa com folder de queimaduras e entrevista após uma semana. As respostas foram comparadas utilizando-se teste estatístico de Fisher. Na primeira entrevista registrouse 60 respostas de situações de risco no grupo controle e 62 no grupo intervenção; na segunda, aumentou para 61 e 80 indicações, respectivamente. Na primeira entrevista, $90,0 \%$ dos participantes do grupo controle e $80,0 \%$ do grupo intervenção verbalizaram acreditar que a queimadura infantil pode ser evitada; na segunda, esse item diminuiu para $84,0 \%$ e aumentou para $100,0 \%$, respectivamente. Este estudo mostrou a importância da orientação com folder de queimaduras em ambiente doméstico $^{(7)}$.

É necessário enfatizar que a utilização do material escrito não substitui a informação verbal que se dá através da relação interpessoal, paciente-família e Enfermagem, que visa um processo efetivamente educativo por meio do diálogo, pois ensinar não é o simples ato de transmitir ou de depositar informações, educar não é a mera transferência de conhecimentos, mas sim conscientização e testemunho de vida, senão não terá eficácia ${ }^{(8)}$.

Embora existam vários manuais sendo utilizados como subsídio à educação dos pacientes e familiares, pouco se encontra escrito sobre como elaborá-los. Há necessidade de construção de projetos de desenvolvimento, da busca do conhecimento científico do tema a ser trabalhado, da escolha de uma linguagem acessível e a priorização de informações relevantes, da participação dos profissionais envolvidos, assim como dos pacientes e familiares e, por fim, da necessidade constante de atualização dos mesmos, além da convicção de que o rigor científico é indispensável para garantir sua qualidade ${ }^{(5)}$.

A produção de materiais educativos para consumo nos serviços de saúde tem se baseado mais na experiência do atendimento, contemplando algumas dúvidas e questionamentos comuns que o profissional de saúde "pensa serem" do paciente. Em um estudo realizado verificou-se as motivações e opiniões de profissionais da saúde 
sobre a produção de impressos hospitalares, apontando para a ausência de pesquisas prévias às produções e baixo ou nulo investimento em pesquisas que verificassem a recepção das mensagens junto aos públicos para os quais se destinam ${ }^{(9)}$.

Nesse sentido, para que se aumentem as chances do material escrito ser eficaz, seu uso deve ser bem planejado considerando-se questões como, por exemplo, a sua elaboração, a linguagem, o conteúdo, a abordagem pedagógica a ser utilizada, relacionando esses aspectos com o público para qual será destinado. Os profissionais de saúde, produtores de material impresso, devem ter em mente essas considerações para atenderem a uma real necessidade ${ }^{(6)}$.

Um estudo de revisão de literatura realizado na Inglaterra teve como objetivo examinar as informações escritas dadas aos pacientes, focando legibilidade, comunicação, adesão ao tratamento e satisfação do paciente. Concluiu-se a partir dele que existe uma vasta quantidade de panfletos e manuais na educação em saúde que tratam sobre o manejo e tratamento de várias doenças, medicações, pré e pósoperatório. Entretanto, relativamente poucos estudos foram realizados para avaliar essa quantidade de informação ${ }^{(10)}$.

O mesmo estudo revelou que os pacientes gostariam de obter mais informações escritas, apesar da quantidade já disponível. Isso sugere que na época que o estudo foi realizado os pacientes não estavam recebendo informações compreensíveis que respondiam suas dúvidas. Muito tem sido escrito sobre a legibilidade, mas será que os profissionais de saúde sabem se a mensagem que querem transmitir atinge os pacientes, melhorando assim a adesão e satisfação deles $^{(10)}$ ? São poucos os estudos criteriosos em relação ao expressivo volume de material impresso, sendo assim, são questionáveis a utilidade e aplicabilidade deste recurso quando não precedido de estudos de demanda e compreensibilidade. Se os profissionais consideram importante manter seus pacientes informados por meio de impressos, os estudos nesse campo deveriam ser mais aprofundados, por razões tanto econômicas quanto éticas ${ }^{(10)}$.

Sabemos das dificuldades e escassez de recursos físicos, humanos, estruturais e materiais em grande parcela dos serviços de saúde. Essa carência põe em risco a prática educativa, tornando-a monótona, desestimulante e repetitiva, para o profissional e para a clientela. Por outro lado, não é possível ficarmos imobilizados até que mudanças macroestruturais e sociais ocorram ${ }^{(11)}$. 
É conveniente levar em consideração os custos para a produção dos materiais escritos que encontramos nas salas de espera, tanto em hospitais quanto em centros de saúde da comunidade. Pode-se argumentar que grande parte destas informações é desperdiçada, a menos que sejam corretamente avaliadas, que sejam necessárias e sejam apresentadas em formato apropriado ${ }^{(10)}$.

Diante do exposto, considerou-se importante verificar mais profundamente as características da comunicação dos materiais escritos impressos elaborados por enfermeiros brasileiros, que subsidiam as orientações em Enfermagem. 


\section{OBJETIVOS}

\subsection{OBJETIVO GERAL}

Analisar as características da comunicação dos materiais escritos impressos elaborados por enfermeiros brasileiros, que subsidiam as orientações em Enfermagem.

\subsection{OBJETIVOS ESPECÍFICOS}

- Identificar os artigos científicos desenvolvidos por enfermeiros brasileiros sobre as características da comunicação dos materiais escritos impressos, que subsidiam as orientações em Enfermagem.

- Caracterizar os autores, tipos de pesquisa, objetivos propostos e procedimentos metodológicos utilizados;

- Analisar descritivamente os resultados das pesquisas produzidas para a construção do conhecimento na área. 


\section{REFERENCIAL TEÓRICO}

\subsection{ABORDAGENS PEDAGÓGICAS}

Ao abordar "fatores pedagógicos" incluem-se nesta categoria todos os processos relacionados com o ensino-aprendizagem das tecnologias que um determinado grupo elegeu como apropriadas para seu sistema de produção. Todos os processos educativos, assim como suas respectivas metodologias e meios, têm por base uma determinada pedagogia, isto é, uma concepção de como se consegue que as pessoas aprendam alguma coisa e, a partir daí, modifiquem seu comportamento ${ }^{(12)}$.

Toda ação pedagógica implica em decisões sobre que conhecimentos ensinar, para quem e como fazê-lo. Em cada momento histórico, em cada sociedade, em cada realidade social, o processo educacional é portador de uma ideologia, e por meio de uma doutrina pedagógica leva o educando a integrar-se ao sistema em que vive ${ }^{(13)}$.

Os educandos atualmente provêm de uma sociedade multicultural com uma diversidade de famílias, culturas, raças, línguas e níveis socioeconômicos. O ideal é oferecer a todos um sistema educativo eficiente e respeitador, que os prepare eficazmente para as realidades acadêmicas, profissionais e sociais do século $\mathrm{XXI}^{(8)}$.

A aprendizagem é um processo integrado no qual toda a pessoa (intelecto, afetividade, sistema muscular) se mobiliza de maneira orgânica, sendo um processo qualitativo, em que a pessoa fica mais bem preparada para novas aprendizagens, com uma transformação estrutural de sua inteligência; e não um processo quantitativo, pelo simples aumento numérico do conhecimento ${ }^{(14)}$.

Existem três principais abordagens pedagógicas para a consecução das práticas educativas no âmbito da formação de força de trabalho: o da transmissão de conhecimentos, o tecnicista ou de condicionamento e o da problematização da realidade, citando o primeiro como o mais amplamente difundido e utilizado pelos docentes na atualidade ${ }^{(13)}$.

A Pedagogia de Transmissão parte da premissa de que as ideias e conhecimentos são os pontos mais importantes da educação e, como consequência, a experiência fundamental que o aluno deve viver para alcançar seus objetivos é a de receber o que o professor ou o livro lhe oferecem. O aluno é considerado como uma 
"página em branco" onde novas ideias e conhecimentos de origem exógena serão impressos $^{(12)}$.

É necessário observar que a pedagogia de transmissão não está circunscrita nas situações de educação formal, mas quase sempre pode estar presente nas situações de educação não-formal. Assim, quando se criticam os agentes de treinamento em campos profissionalizantes de usar um estilo autoritário e vertical na transmissão de, por exemplo, novos conhecimentos técnicos, em geral o que se pretende denunciar é uma entrega de conhecimentos sem o correspondente esforço para desenvolver as habilidades intelectuais (observação, análise, avaliação, extrapolação, compreensão etc.) ${ }^{(12)}$.

As consequências do uso, de maneira prolongada e dominante, desta pedagogia em nível individual são a passividade, a falta de atitude crítica, a relação dogmática com as fontes de informação, a valorização isolada do saber intelectual e a incapacidade de transformar a realidade. No âmbito coletivo e social obtêm-se grupos passivos e acríticos, adotando indiscriminadamente modelos e padrões de outras regiões, manipuláveis por comunicação de massa ou reproduzindo padrões historicamente estabelecidos, desvinculados do contexto social de sua realidade ${ }^{(12)}$.

A pedagogia conducionista ou tecnicista difere da anterior por considerar mais importante o aprender a "fazer" e não o aprender a "saber". O principal objetivo dessa pedagogia é a formação de indivíduos eficientes do ponto de vista da produtividade, daí sua grande preocupação com a técnica ${ }^{(12)}$.

Esta escola pedagógica se concentra no modelo da conduta de estímulos e recompensas capaz de "condicionar" o aluno a emitir respostas desejadas pelo professor. O processo consiste em que o professor estabeleça objetivos instrumentais de realização quantitativamente mensuráveis e programe uma estratégia de modelagem baseada em uma sequência de pequenos passos, reforçando-se ou recompensando-se o aluno quando a resposta emitida coincide com a resposta esperada $^{(12)}$.

Os métodos emergentes desta pedagogia deveriam ser utilizados somente depois que os alunos já houvessem desenvolvido sua consciência crítica e sua capacidade de problematizar sua própria realidade mediante outros métodos menos condicionadores $^{(12)}$. Sua utilização poderá formar indivíduos competitivos e 
individualistas. No âmbito coletivo produz grupos conformados com a realidade social, pouco criativos e dependentes de tecnologia e saberes externos ${ }^{(12)}$.

Já a Pedagogia da Problematização parte da base que, em um mundo de mudanças rápidas, o importante não são os conhecimentos ou ideias nem os comportamentos corretos e fáceis que se espera, mas sim o aumento da capacidade do aluno, participante e agente da transformação social, para detectar os problemas reais e buscar para eles soluções originais e criativas. Por esta razão, a capacidade que se deseja desenvolver é a de fazer perguntas relevantes em qualquer situação, para entendê-las e resolvê-las adequadamente ${ }^{(12)}$.

Em termos de capacitação em gestão e produtividade não é tão importante, dentro do contexto desta pedagogia, a transmissão fiel de conceitos, fórmulas, receitas e procedimentos, nem tampouco a aquisição de hábitos fixos e rotinas de trabalho que conduzem a uma boa gestão. Em certas situações, é mais importante e urgente desenvolver a capacidade de observar a realidade imediata ou circundante como a global e estrutural; detectar todos os recursos de que se possa lançar mão; identificar os problemas que obstaculizam um uso eficiente e equitativo dos ditos recursos; localizar as tecnologias disponíveis para usar de maneira mais adequada os recursos ou até inventar novas tecnologias apropriadas; e encontrar formas de organização do trabalho e da ação coletiva para conseguir tudo o que foi anteriormente citado. Essa pedagogia não separa a transformação individual da transformação social, pela qual ela deve desenvolver-se em situação grupal ${ }^{(12)}$.

Paulo Freire sempre defendeu a educação problematizadora, para que o homem pudesse libertar-se e emancipar-se. Afirma que a ação de educar pode e deve ser muito mais que um processo de treinamento ou domesticação; um processo que nasce da observação e da reflexão e culmina na ação transformadora. Educar não é a mera transferência de conhecimentos, mas sim conscientização e testemunho de vida, é construir, é libertar o ser humano das cadeias do determinismo neoliberal, reconhecendo que a história é um tempo de possibilidades. Educar é um "ensinar a pensar certo" como quem "fala com a força do testemunho". É um "ato comunicante, co-participado", de modo algum produto de uma mente "burocratizada". No entanto, toda a curiosidade de saber exige uma reflexão crítica e prática, de modo que o próprio discurso teórico terá de ser aliado à sua aplicação prática ${ }^{(8)}$. 
O educador que "castra" a curiosidade do educando em nome da eficácia da memorização mecânica do ensino dos conteúdos, tolhe a liberdade do educando, a sua capacidade de aventurar-se. Não forma, "domestica"(8).

O relacionamento professor-aluno precisa estar pautado no diálogo, ambos se posicionando como sujeitos no ato do conhecimento numa relação horizontal. $\mathrm{O}$ autoritarismo que permeava a relação da educação tradicional precisa ser banido para dar lugar à pedagogia do diálogo. Contudo, esta relação horizontal não acontece de forma imposta, ocorre naturalmente quando educando e educador conseguem se colocar na posição do outro, tendo a consciência de que ao mesmo tempo são educandos e educadores $^{(15)}$. Neste diálogo insere-se também o conceito de educação para Freire, no qual ninguém sabe tudo, ninguém é inteiramente ignorante. A educação não pode ser diminuidora da pessoa humana, mas precisa "levar à redenção"(15).

Para ilustrar a pedagogia da problematização Charles Maguerez propõe o "método arco", conforme exposto na Figura 1:

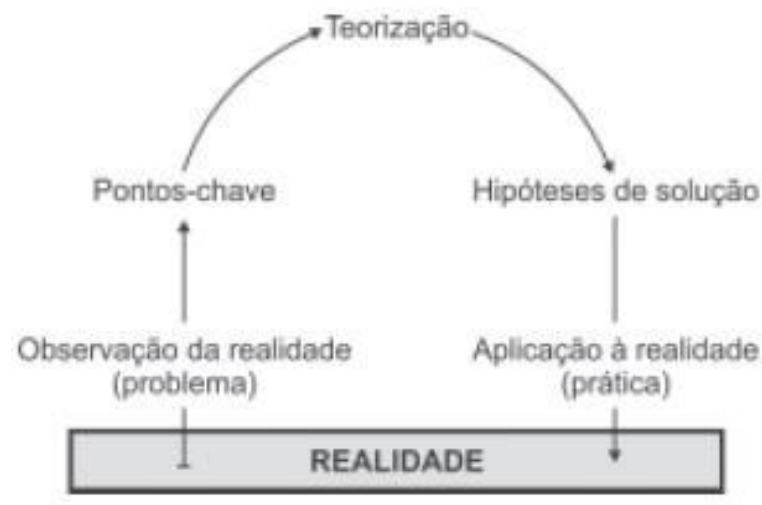

Figura 1 - Arco de Maguerez (apud BORDENAVE; PEREIRA, 2008).

A figura 1 mostra que o processo "ensino-aprendizagem", relacionado com um determinado aspecto da realidade, deve começar levando os educandos a observar a realidade em si, com seus próprios olhos. Quando isto não é possível, os meios audiovisuais, modelos, etc., permitem trazer a realidade até os educandos, mas naturalmente, com perdas de informação inerentes a uma representação do real. Ao observar a realidade, os alunos expressam suas percepções pessoais, efetuando assim uma primeira "leitura sincrética" ou ingênua da realidade ${ }^{(12)}$. 
Em um segundo momento ou fase, os educandos reparam no que foi observado o que é verdadeiramente importante do que é puramente superficial ou contingente. Melhor explicitando, identificam os pontos-chave do problema ou assunto em questão, as variáveis mais determinantes da situação. Esta etapa da problematização constitui uma das razões mais importantes da superioridade desta pedagogia sobre as de transmissão e condicionamento ${ }^{(12)}$.

Em um terceiro momento, os educandos passam à teorização do problema ao perguntar o porquê das coisas observadas. Ainda que o papel do educador seja importante como estímulo para que os educandos participem ativamente, nesta fase de teorização sua contribuição é fundamental, pois a tarefa de teorizar é sempre difícil e ainda mais quando não se possui o hábito de fazê-lo, como é, em geral, o caso de adultos em treinamento. Trata-se, então, do caso de recorrer a conhecimentos científicos contidos no dia-a-dia e a outras maneiras simplificadas e fáceis de comprovação ${ }^{(12)}$.

Se a teorização é bem sucedida o aluno chega a "entender" o problema não somente em suas manifestações empíricas ou situacionais, assim como os princípios teóricos que o explicam. Essa etapa de teorização que compreende operações analíticas da inteligência é altamente enriquecedora e permite o crescimento mental dos alunos ${ }^{(12)}$.

Confrontada a Realidade com sua Teorização, o educando se vê naturalmente movido a uma quarta fase: a formulação de Hipóteses de Solução para o problema em estudo. É quando deve ser cultivada a originalidade e a criatividade na inventiva para que os educandos deixem sua imaginação livre e se acostumem a pensar de maneira inovadora. Porém, como a teoria em geral é muito fértil e não tem amarras situacionais, algumas das hipóteses apresentadas podem ser válidas a princípio, porém não na prática. Esta etapa deve conduzir o aprendiz a levar a termo provas de viabilidade e factibilidade, confrontando suas hipóteses de solução com os condicionamentos e limitações da própria realidade. A situação de grupo ajuda a esta confrontação "ideal-real". Outra vantagem desta pedagogia: o aluno usa a realidade para aprender com ela, ao mesmo tempo em que se prepara para transformá-la ${ }^{(12)}$.

$\mathrm{Na}$ última fase, o educando pratica e fixa as soluções que o grupo encontrou como sendo mais viáveis e aplicáveis. Aprende a generalizar o aprendido para utilização em situações diferentes e a discriminar em que circunstâncias não é 
possível ou conveniente a aplicação, sabendo a qual escolher. Por meio do exercício aperfeiçoa sua destreza e adquire domínio e competência no manejo das técnicas associadas à solução do problema ${ }^{(12)}$.

$\mathrm{Na}$ Enfermagem, encontramos artigos que utilizam o método arco, proposto por Charles Maguerez, um deles, intitulado: O método arco no ensino de préoperatório de pacientes laringectomizados, estudo qualitativo que teve como objetivo planejar, implementar e avaliar a ação educativa pré-operatória aos pacientes laringectomizados, baseada no método arco. Utilizaram-se de entrevistas informais e em abordagem individualizada e, como estratégias para fornecer subsídios teóricos e práticos específicos, empregaram-se um álbum seriado e folheto de orientação. A aplicação do método mostrou-se útil, haja vista o impacto que resultou na adaptação do paciente à realidade no pós-operatório.

Cada opção pedagógica, quando exercida de maneira dominante durante um período prolongado, tem consequências discerníveis sobre a conduta individual e também, o que é mais importante, sobre o comportamento da sociedade em seu conjunto $^{(12)}$. Existem momentos no processo de ensinar em que tudo que se requer é transmitir informação, e outros em que certos automatismos devem ser fixados pelo aluno para a execução de sequências rígidas de operações. Na Enfermagem, temos como exemplo os procedimentos técnicos tais como mensuração da temperatura, aferição de pressão, lavagem das mãos, entre outros.

O que não se pode é perder de vista o objetivo fundamental da ação educativa, que consiste em desenvolver a personalidade integral do aluno, sua capacidade de pensar e raciocinar, assim como seus valores e hábitos de responsabilidade, cooperação, etc ${ }^{(12)}$.

A trajetória das práticas educacionais e assistenciais de Enfermagem tem atendido aos interesses econômicos, políticos e sociais. As ações educativas não se dão ao acaso, produzem e são reproduzidas no interior da sociedade e dos interesses materiais e imaginários em determinados momentos históricos ${ }^{(13)}$. Essas práticas têm contribuído para a manutenção do modelo médico-biológico de atenção à saúde, hegemônico no imaginário da sociedade, ao sustentar na prática educativa junto aos usuários dos serviços de saúde a organização de grupos a partir de patologias já instaladas (infectocontagiosas e crônico-degenerativas) ${ }^{(13)}$. 
O uso prolongado e dominante da opção pedagógica da transmissão de conhecimentos gerou distorções nos processos de formação de força de trabalho em saúde, tanto no âmbito individual quanto no coletivo. No âmbito individual, a passividade, a falta de atitude crítica, a relação dogmática com as fontes de informação, a valorização isolada do saber intelectual e o desinteresse para se transformar a realidade. Já no âmbito coletivo, há ocorrência de grupos passivos e acríticos que adotam indiscriminadamente modelos e padrões de outras regiões, manipuláveis por comunicação de massa ou reprodutores de padrões historicamente estabelecidos e desvinculados do contexto social de sua realidade ${ }^{(13)}$.

Além disso, o uso prolongado dessa opção pedagógica na formação dos profissionais também se reflete nas escolhas das práticas educativas que os enfermeiros têm utilizado com os pacientes. Em um trabalho cujo objetivo era estudar sobre educação de pacientes por meio da identificação dos aspectos conceituais e operacionais da atividade educativa do enfermeiro com o paciente/cliente, evidenciou-se, a partir da análise dos estudos, que a educação do paciente é uma ação instrumental e de proteção do enfermeiro para com o paciente, sendo o fornecimento de informação (orientação) sua essência. Destacam também que ao longo dos anos houve um predomínio dos defensores do Modelo Preventivo de Saúde (fundamentado no Modelo Médico ou Tradicional) e, em segundo lugar, dos seguidores da Visão Educacional Humanística ${ }^{(16)}$.

$\mathrm{Na}$ literatura brasileira de Enfermagem as duas concepções são relacionadas, porém, são contraditórias: a) a concepção centrada no modelo médico (no qual a aceitação ou adesão ao tratamento é a palavra chave e cuja linguagem tem os significados de aceitação, adesão, planejamento para os pacientes, mudança de comportamento, paciente passivo, dependência, necessidades determinadas pelos profissionais); b) e a centrada no paciente (a palavra chave é autonomia e a linguagem tem os significados de independência, participação do paciente no planejamento, paciente ativo, conscientização e emancipação) ${ }^{(16)}$.

O mesmo estudo faz referência aos recursos utilizados na educação de pacientes, que são: demonstrações, palestras, álbuns seriados, cartazes, manual de informação, diálogo e demonstração com devolução. Duas das grandes falhas dos trabalhos analisados foram a não explicitação da justificativa para a utilização desses 
recursos, em relação aos grupos de pacientes a que foram aplicados, e a não avaliação do emprego desses recursos ${ }^{(16)}$.

A partir desses resultados, é necessário descobrir quais são os valores e desejos que os enfermeiros imprimem ao conteúdo de seus projetos de educação para a saúde e de educação continuada e como introjetam estes sonhos e desejos nos seus educandos. Assim, por exemplo, ao orientar famílias de idosos quanto à assistência de Enfermagem domiciliária, o conteúdo e técnicas metodológicas condicionam e reforçam o idoso a assumir o papel socialmente determinado na sociedade brasileira de dependente dos familiares e consumidor de medicamentos ou buscam contribuir para que o idoso encontre, interagindo com sua família, alternativas para que tenha mais prazer e dignidade no seu ato cotidiano de viver ${ }^{(13)}$ ?

Apesar das tendências pedagógicas ainda coexistirem em nossa realidade e existirem críticas a cada uma delas, parece-nos que a prática educativa norteada pela pedagogia da problematização parece ser a mais adequada à prática educativa em saúde. Além de promover a valorização do saber do educando, instrumentalizando-o para a transformação de sua realidade e de si mesmo, possibilita efetivação do direito da clientela às informações de forma a estabelecer sua participação ativa nas ações de saúde, assim como o desenvolvimento contínuo de habilidades humanas e técnicas no trabalhador de saúde, fazendo com que este exerça um trabalho criativo. Estas características e consequências convergem para uma sociedade mais democrática em prol do desenvolvimento das potencialidades dos indivíduos e coletividade, estando em concordância com os princípios e diretrizes da Promoção da Saúde ${ }^{(17)}$.

Com a utilização da Pedagogia da Problematização, a enfermeira, enquanto educadora, pode desenvolver atividades junto ao paciente para aumentar a sua capacidade em detectar problemas e buscar soluções criativas e adequadas à sua realidade. O importante não são os conhecimentos, ideias ou comportamentos esperados e corretos em si, mas o desenvolvimento da capacidade do paciente de enfrentar os seus problemas e tomar decisões adequadas às suas necessidades ${ }^{(18)}$. 


\subsection{COMUNICAÇÃO INTERPESSOAL E ENFERMAGEM}

A origem da palavra comunicar está no latim comunicare, que tem por significado "por em comum"(19). É um processo de compreender, compartilhar mensagens enviadas e recebidas, sendo que as próprias mensagens e o modo como se dá seu intercâmbio exerce influência no comportamento das pessoas nele envolvidas, a curto, médio e longo prazo ${ }^{(20)}$.

Além disso, podemos afirmar que comunicar é o processo de transmitir e receber mensagens por meio de signos, sejam eles símbolos ou sinais. Os signos são estímulos que transmitem uma mensagem; qualquer coisa que faça referência a outra coisa ou ideia. Dependendo do contexto, a maioria dos signos humanos possui mais de uma interpretação possível; são, portanto, sinais e não símbolos ${ }^{(19)}$. Um exemplo de símbolo é o estetoscópio no pescoço de uma pessoa no corredor de um hospital, identificando-a, inicialmente, como um médico. Já a roupa branca constitui um exemplo de sinal, que pode identificar várias categorias profissionais: médico, enfermeiro, dentista, etc ${ }^{(19)}$.

Muitos autores têm estudado as teorias da comunicação, dentre eles Littlejohn, um clássico da literatura em comunicação humana, que aborda entre vários referenciais teóricos, o interacionismo simbólico, seus fundamentos e suas proposições teóricas básicas. Aborda a teoria dos signos, incluindo a codificação verbal e não-verbal, e ainda, as teorias de significado, pensamento, informação, persuasão e mudança. Nas teorias de comunicação em pequenos grupos aborda a natureza dos grupos, teorias de manutenção e motivação de grupo, as fases de desenvolvimento dos grupos e a teoria de efeitos interpessoais nos grupos ${ }^{(21)}$.

Já Stefanelli desenvolve conceitos e estratégias da comunicação terapêutica, bem como fatores que podem impedir sua utilização adequada, enfatizando a necessidade de associar o conhecimento em comunicação às demais competências do enfermeiro. Para a autora, a comunicação é um processo de compreender e compartilhar mensagens recebidas e enviadas. Isso permite entender que as pessoas encontram-se constantemente envolvidas por um campo interacional ${ }^{(20)}$.

A partir desses conceitos, refletindo nas relações interpessoais, sabemos que basicamente nos comunicamos nas dimensões verbal e não verbal. A comunicação verbal é aquela associada às palavras expressas por meio da linguagem escrita ou 
falada. Quando interagimos verbalmente com alguém estamos tentando nos expressar ou ajudando alguém a se expressar, transmitindo, clarificando ou validando a compreensão de $\operatorname{algo}{ }^{(19)}$.

A comunicação não verbal é toda expressão humana percebida entre as pessoas, exceto as palavras por elas mesmas; sua função é complementar, contradizer e substituir a comunicação verbal, além de demonstrar sentimentos. Pode também ser definida como toda informação obtida por meio de gestos, posturas, expressões faciais, orientações do corpo, singularidades somáticas naturais ou artificiais, organização dos objetos no espaço e até pela relação de distância mantida entre os indivíduos $^{(19)}$.

Para que o processo comunicativo se inicie, tanto na comunicação verbal quanto na não verbal, há sempre alguém (emissor) com uma curiosidade, necessidade de transmitir ou saber algo ou um conteúdo (mensagem) que precisa ser esclarecido, dito para outra pessoa. $\mathrm{O}$ emissor sente-se, então, estimulado a iniciar um contato interpessoal e pensa em como fazê-lo (codificação) e como enviá-lo (canal) a fim de tornar comum o conteúdo de sua informação ou ideia para a outra pessoa (receptor). Esta, por sua vez, reagirá à mensagem recebida apresentando sua reação (resposta) $^{(22)}$.

Para o enfermeiro, profissional que acompanha o ser humano em todo o seu ciclo vital, a comunicação representa uma das principais ferramentas de trabalho, indispensável à assistência, em todas as áreas de atuação ${ }^{(23)}$, pois a base do seu trabalho são as relações humanas, sejam elas entre a equipe multidisciplinar como, por exemplo, na passagem de plantão, nos registros em prontuários para continuidade da assistência, com os pacientes e seus familiares na prevenção e promoção da saúde.

Nessa relação enfermeiro-paciente, para que a comunicação seja efetiva, precisamos considerar que o diálogo se faz entre pessoas, e cada pessoa é um mundo à parte com seu subjetivismo, suas experiências, sua cultura, seus valores, seus interesses e suas expectativas. A percepção pessoal funciona como uma espécie de filtragem que condiciona a mensagem segundo a própria lente. Ouvimos e vemos conforme a nossa percepção ${ }^{(19)}$.

Com o objetivo de otimizar a assistência de Enfermagem, a comunicação efetiva emerge como instrumento que tenta diminuir conflitos, mal-entendidos e atingir objetivos definidos para a solução de problemas detectados na interação com 
os pacientes. O profissional da saúde precisa decodificar, decifrar e perceber o significado da mensagem que o paciente envia, para só então estabelecer um plano de cuidados adequado e coerente com as suas necessidades ${ }^{(19)}$.

Para tanto, é preciso estar atento aos sinais de comunicação verbal e não verbal emitidos por e pelo profissional. Para ajudar o paciente precisamos conhecêlo. A nossa capacidade de ouvir, durante a comunicação, faz-se extremamente necessária, porque descobrimos os recursos que o doente tem para enfrentar os seus problemas de saúde e quais são as suas expectativas em relação ao tratamento. Para nos expressarmos bem, foi necessário que tivéssemos sido bons ouvintes, pois, daí então somos capazes de perceber que o que é bom para mim não é necessariamente bom para o outro ${ }^{(19)}$.

É considerada comunicação adequada aquela apropriada a uma determinada situação, pessoa, tempo, e que atinge um objetivo definido. Envolve uma preparação especial levando em conta a mensagem a ser transmitida, o emissor, o receptor e a técnica de comunicação necessária ${ }^{(19)}$. É somente através dela que o profissional poderá ajudar o paciente a conceituar seus problemas, enfrentá-los, visualizar sua participação na experiência e alternativas de solução dos mesmos, além de auxiliá-lo a encontrar novos padrões de comportamento ${ }^{(19)}$. Quanto maior o domínio da habilidade de comunicar-se, maiores são as chances de alcançar os objetivos da assistência de Enfermagem. A comunicação deve ser considerada como capacidade ou competência interpessoal a ser adquirida pelo enfermeiro, não importando sua área de atuação ${ }^{(20)}$.

Um estudo que buscou os significados para uma comunicação competente, entrevistando enfermeiros atuantes como docentes e com experiência comprovada na área da comunicação e Enfermagem, encontrou resultados que possibilitam compreender que uma comunicação é competente quando: é um processo interpessoal que atinge o objetivo dos comunicadores; pressupõe que eles tenham conhecimentos básicos de comunicação; tenham consciência do verbal e do não verbal nas interações; clareza e objetividade; promove também o autoconhecimento, além de possibilitar uma vida autêntica ${ }^{(24)}$.

$\mathrm{O}$ conceito de comunicação adequada também se aplica à forma de comunicação verbal escrita, uma vez que esta está inserida na prática profissional do 
enfermeiro nas atividades administrativas e de gestão, nas assistenciais e nas ações relacionadas ao ensino e à pesquisa em Enfermagem ${ }^{(25)}$.

A escrita geralmente representa um pensamento mais elaborado, pois podemos filtrar a emoção e a espontaneidade. Os registros devem ser objetivos, completos, desprovidos de impressões pessoais generalizadas, e compreensíveis para todos os que se destinam ${ }^{(19)}$.

A comunicação escrita no processo de Enfermagem apresenta-se em dois eixos fundamentais: o primeiro diz respeito aos aspectos éticos e legais de que se revestem os registros da assistência, e o segundo relaciona-se à qualidade assistencial $^{(25)}$.

Por meio dos registros efetuados pela equipe de Enfermagem é possível obter informações sobre a assistência prestada de forma a assegurar a comunicação entre os membros da equipe de saúde e garantir a continuidade do cuidado. Os registros no prontuário do paciente, da assistência a ele prestada, abrangem diversos aspectos e respaldam ética e legalmente o profissional responsável pelo cuidado ${ }^{(25)}$. São fonte de informações para questões jurídicas, de pesquisas, de educação e outras atividades relacionadas $^{(26)}$.

Os registros de Enfermagem constituem importante fator para a tomada de decisão e alcance da qualidade do cuidado $^{(26)}$, oferecem subsídios para que o enfermeiro obtenha uma visão holística sobre suas ações, relacionada à qualidade de gestão, da assistência e da relação quântico-econômico-financeira da unidade, tendo sempre em vista o bem-estar do ser humano ${ }^{(27)}$.

A gestão de Enfermagem pressupõe ainda a emissão de memorandos, e-mails, solicitações e relatórios que requerem linguagem formal, clareza e precisão de fatos e dados, lógica, análise crítica e argumentação, prática que necessita de exercício cotidiano $^{(25)}$.

Além dessas atividades, o enfermeiro elabora manuais de normas e rotinas que são utilizados por toda a equipe de Enfermagem, e também materiais educativos impressos para pacientes e familiares, que podem ser apresentados como folhetos, panfletos, folder, livreto, cartilha, cuja proposta é proporcionar informação sobre promoção da saúde, prevenção de doenças, modalidades de tratamento e autocuidado. 
O processo de aquisição, aproveitamento e aprofundamento de conhecimentos, de domínio de habilidades e de tomadas de decisão é facilitado, entre outros recursos, pela utilização de material impresso. Assim sendo, para esse processo, o material escrito tem tripla função: de reforçar as informações e discussões orais, de servir como guia de orientações para os casos de dúvidas posteriores e auxiliar nas tomadas de decisões ${ }^{(23)}$.

Sendo assim, o uso do material escrito impresso como instrumento no cuidado com o paciente subsidia as orientações de Enfermagem, porém, para que seu uso seja efetivo, é necessário a empenho do profissional desde o momento da elaboração do material até a sua validação. É necessário selecionar quais informações realmente são importantes para constar no manual, porque ele precisa ser atrativo, objetivo, não pode ser muito extenso, mas deve dar uma orientação significativa sobre o tema. Precisa ser de fácil compreensão e atender às necessidades específicas de uma determinada situação de saúde para que as pessoas se sintam estimuladas a lê-lo ${ }^{(5)}$.

O preparo de material impresso ou material escrito, portanto, é precedido de algumas etapas comuns ao processo de desenvolvimento de qualquer plano de comunicação em saúde: identificação do público-alvo, a quem a descrição e as informações detalhadas ajudarão no desenvolvimento de mensagens mais relevantes e na identificação dos canais mais apropriados para alcançá-lo, incluindo tais informações, dados demográficos, características culturais, padrões comportamentais, status de saúde que podem ser conhecidos utilizando-se vários métodos $^{(23)}$.

Em relação ao texto, cada um tem estilo próprio, razão pela qual a linguagem rica em termos técnicos encontrada nos prontuários dos pacientes difere da utilizada nos manuais educativos para os pacientes e seus familiares, livre de jargões e de termos profissionais; da mesma forma, difere da utilizada para divulgação de pesquisas científicas em Enfermagem, que requer o estilo acadêmico, uma vez que busca atingir a comunidade científica ${ }^{(25)}$.

É importante destacar que a fase de elaboração deve ser seguida da avaliação da versão preliminar do material, com a participação do público-alvo destinatário da mensagem. Esse procedimento assegura o conhecimento da qualidade do material quanto à compreensão, aceitação da mensagem, adequação cultural, ao estilo, à 
apresentação, eficácia apontando para possíveis necessidades de reajustes e modificações. Procedimentos como entrevistas, aplicação de questionário e grupo focal, podem ser utilizados para se testar o material. O julgamento e a apreciação do material por profissionais de outras áreas com conhecimento em produção de material educativo, e por profissionais de saúde especializados e envolvidos como o público-alvo oferecerá informações, sugestões e opiniões que facilitarão a tomada de decisões. Essa avaliação é imprescindível, mas não garante a aprendizagem e a mudança de comportamento. Somente avaliação voltada para os resultados de saúde objetivados pela aplicação do material poderá assegurar a eficácia ${ }^{(23)}$.

Nessa etapa, é necessário que estejamos abertos a críticas para construir algo que realmente venha atender as expectativas e as necessidades das pessoas, as quais, certamente, possuem conhecimentos e interesses diferentes dos nossos ${ }^{(5)}$.

Sendo assim, urge que os profissionais de saúde, criadores e produtores de material impresso para pacientes considerem que a mensagem deve ser bem planejada, correta, fácil de ler, compreensível e que atinja o público-alvo. O criador de uma mensagem deve atentar à redução dos ruídos que interferem no processo de comunicação, bem como, adotar e desenvolver mecanismos que facilitem a leitura, melhorem a legibilidade e motivem o leitor ${ }^{(23)}$.

\subsection{ELABORAÇÃO DE MATERIAL EDUCATIVO ESCRITO IMPRESSO}

Para escrevermos um texto e, principalmente, torná-lo acessível, ou seja, para que o leitor entenda a mensagem que se quer transmitir, primeiramente se faz necessário compreender a maneira como lemos. Para isso, alguns aspectos relacionados à leitura, como por exemplo, o índice de legibilidade, deve ser considerado.

O índice de legibilidade (IL) refere-se ao grau de escolaridade exigido de um leitor para que possa entender uma determinada passagem escrita. $\mathrm{O}$ uso do material impresso é mais econômico e mais amplamente utilizado, mas nem sempre está de acordo com as características do paciente, não atendendo, portanto, às suas necessidades, principalmente no que se refere ao $\mathrm{IL}^{(28)}$. 
As fórmulas para avaliar o IL do material escrito predizem o nível de escolaridade e medem a dificuldade estrutural do texto (palavras, sílabas e extensão das sentenças), não considerando outros fatores que interferem na compreensão do material (dificuldades conceituais, objetividade, ilustração, formato etc.). Um material apresentará um IL apontando para o grau de escolaridade mais alto quando suas sentenças forem mais longas e/ou quanto mais palavras polissílabas forem encontradas no texto. Um material escrito que apresente um IL que exija entre cinco e sete anos de escolaridade é adequado, no que se refere à facilidade do texto, para o

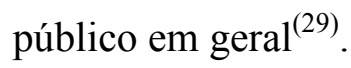

Essas questões nos fazem refletir e considerar que o processo da leitura não é um mero "passar de olhos" pelas linhas, mas sim uma atividade que utiliza diversos níveis do conhecimento que interagem entre si e que exige do leitor um conhecimento linguístico, textual e de mundo. O processo de leitura se inicia pela percepção da palavra que gera a construção de significados. Esses significados são agrupados em frases com a utilização do conhecimento gramatical identificando as categorias e função dos sintagmas. $\mathrm{O}$ processamento continua até chegar à compreensão ${ }^{(30)}$.

O conhecimento linguístico desempenha um papel central no processamento do texto. Entende-se por processamento aquela atividade pela qual as palavras, unidades discretas, distintas, são agrupadas em unidades ou fatias maiores, também significativas, chamadas constituintes da frase. À medida que as palavras são percebidas, a nossa mente está ativa, ocupada em construir significados, e um dos primeiros passos nessa atividade é o agrupamento em frases (essa etapa do processamento chama-se segmentação ou fatiamento) com base no conhecimento gramatical de constituintes: o tipo de conhecimento que determina o artigo precede nome e este se combina com adjetivo (artigo + nome +adjetivo - "o homem alto"), assim como o verbo com o nome (verbo + nome - "comeu ovos") e assim sucessivamente. Este conhecimento permitirá a identificação de categorias (como por exemplo, sintagma nominal), e das funções desses segmentos ou frases (como sujeito, objeto) que permitirá que esse processamento continue, até se chegar, eventualmente, à compreensão ${ }^{(30)}$.

A falta de conhecimento linguístico pode ocorrer pelo mascaramento do desconhecimento de conceitos sobre determinado assunto que, algumas vezes, pode 
ser superada pela compreensão do contexto ${ }^{(30)}$. Quando o leitor é incapaz de chegar à compreensão por meio de um nível de informação, ele ativa outros tipos de conhecimento para compensar falhas momentâneas.

O conhecimento textual está relacionado com os diversos tipos de texto e de formas de discurso e à classificação do texto do ponto de vista da estrutura. Quanto mais conhecimento textual o leitor tiver, quanto maior a sua exposição a todo tipo de texto, mais fácil será sua compreensão, pois o conhecimento de estruturas textuais e de tipos de discurso determinará, em grande medida, suas expectativas em relação aos textos, expectativas estas que exercem um papel considerável na compreensão ${ }^{(30)}$.

Os textos também podem ser classificados levando-se em consideração o caráter da interação entre autor e leitor, pois quando o autor se propõe a fazer algo, e essa intenção está materialmente presente no texto, através de marcas formais, o leitor se dispõe a "escutá-lo", para depois aceitar, julgar, rejeitar ${ }^{(30)}$.

Já o conhecimento do mundo está relacionado ao conhecimento adquirido informalmente, através de nossas experiências e convívio em uma sociedade, conhecimento este cuja ativação no momento oportuno é também essencial à compreensão de um texto. Trata-se, por exemplo, do tipo de conhecimento que temos sobre o que está envolvido em ir ao médico, comer em um restaurante, assistir a uma aula; podemos descrevê-lo como conhecimento estruturado (porque está ordenado), parcial (porque inclui apenas o que é mais genérico e previsível das situações) sobre um assunto, evento ou situação típica. Esse conhecimento permite uma grande economia e seletividade, pois ao falar ou escrever podemos deixar implícito aquilo que é típico da situação, e focalizar apenas o diferente, o memorável, o inesperado ${ }^{(30)}$. Porém, o conhecimento prévio deve ser mutuamente partilhado, deve ser comum aos interlocutores.

Se fizermos uma relação desses conceitos sobre os materiais escritos de orientação na área da saúde, nossa hipótese é que as orientações não sejam totalmente compreendidas na primeira leitura; pois se o leitor não consegue fazer inferências em relação ao tema, não assimila, então, as informações escritas.

O paciente que nunca frequentou um hospital, não se submeteu a exames de alta complexidade, nunca fez uso de medicações, não conhece os termos relacionados ao tratamento/doença, pode apresentar grandes dificuldades para 
compreensão e, consequentemente, dificuldades para tomar decisões em situações de intercorrências, mesmo com as orientações escritas e verbais dos profissionais. Por outro lado, pacientes submetidos a tratamentos anteriores que já enfrentaram situações iguais ou similares poderiam apresentar maior facilidade ao receberem informações escritas.

Pensando nisso, não bastaria produzir materiais escritos para orientação em saúde de maneira aleatória, a construção dos mesmos precisa ser baseada em conhecimentos científicos e direcionada para o público para qual se destina, por isso, precisamos conhecer o leitor. Compreender um texto escrito não é apenas considerálo um ato cognitivo, pois a leitura é um ato social entre dois sujeitos - leitor e autor que interagem entre si, obedecendo a objetivos e necessidades socialmente determinados. Essa dimensão interacional está explicitada toda vez que a base textual é entendida como materialização de significados e intenções de um dos interagentes à distância via o texto escrito ${ }^{(30)}$.

Além disso, para a compreensão de um texto, estabelecemos atividades metacognitivas que pressupõem reflexão e controle consciente sobre o próprio conhecimento, sobre o fazer e sobre a capacidade ${ }^{(31)}$. A primeira atividade metacognitiva diz respeito ao estabelecimento de objetivos para a leitura. Há evidências de que a nossa capacidade de processamento e de memória melhora significativamente quando é fornecido um objetivo para a leitura, assim como também somos capazes de compreender e lembrar melhor aqueles textos que são importantes para o nosso propósito. Quando a leitura não surge de uma necessidade para chegar a um propósito, não é propriamente leitura, é uma atividade mecânica que não conduz à aprendizagem ${ }^{(31)}$.

A segunda atividade para compreensão do texto é a formulação de hipóteses. Quando formulamos hipóteses, estamos predizendo temas que serão testados. Nessa predição ativamos o nosso conhecimento prévio. É quando enriquecemos, refinamos e checamos esse conhecimento; a partir daí, então, se dá a compreensão do texto ${ }^{(31)}$.

A formulação de hipótese e predicação do texto a ser lido começa pelo título. O principal papel do título é despertar a memória de quem lê, e o ajudar a imaginar os temas e subtemas do texto. É difícil compreender rapidamente um texto se não há alguma indicação que ative seus conhecimentos sobre o assunto. Os bons títulos de textos informativos auxiliam no reconhecimento do conteúdo do texto e, além disso, 
predizem a estrutura e as subdivisões do texto. Dessa forma, ajudam o leitor a tomar decisões que economizam tempo: ler apenas um trecho que interessa mais ou até desistir de ler, porque não interessa no momento ${ }^{(32)}$.

Refletindo sobre essas questões em relação aos materiais escritos de orientação na área da saúde, compreendemos a necessidade de, antes de elaborar um material, ser feita uma pesquisa prévia com o público para o qual esse material será destinado a fim de descobrirmos quais são os interesses, o que é necessário esclarecer e registrar. Na primeira página do material, por exemplo, pode haver uma apresentação do material explicando o objetivo do mesmo e o que ele pretende oferecer aos pacientes. Além disso, pode conter a orientação, de maneira autoexplicativa, de lerem primeiramente os tópicos que tenham mais interesse.

A leitura reflexiva dos estudos relacionados a materiais impressos, que expõem os resultados mais positivos, ou seja, que demonstraram a eficácia do uso sugere que estes foram colhidos nos campos onde ocorreram as aproximações pessoais mais enriquecedoras, por isso são recomendados iniciativas de produção de materiais educativos incorporando o paciente como sujeito do conhecimento, e não apenas como público-alvo de produtos construídos fora da realidade de vida da pessoa $^{(6)}$. É recomendável também questionar o público alvo quanto à entrega do material escrito, quando os mesmos gostariam de receber o material, ou seja, quando acham que seria o momento mais oportuno.

Outro aspecto a ser considerado é a compreensão rápida do que se lê. Para compreender a frase inteira é preciso manter na memória imediata o trecho já lido; sendo assim, os períodos curtos são mais fáceis de ler, por causa dos limites da memória imediata. Por outro lado, os períodos longos e complicados podem ser considerados ilegíveis, porque quando o leitor chega ao ponto final, já não se lembra do começo; sendo assim, é necessário reler o trecho para compreender o restante. O leitor se sente desestimulando e abandona a leitura ${ }^{(32)}$.

Para contribuir com a leitura rápida, os textos informativos devem ser compostos por frases curtas de até 22 palavras com vocábulos comuns e conhecidos. As palavras inúteis são ineficazes e tornam as frases compridas ${ }^{(32)}$. Por exemplo, se em uma cartilha de orientações para leigos, o texto que informasse sobre o que é quimioterapia fosse: "A quimioterapia é uma das modalidades terapêuticas do tratamento do câncer, que tem como objetivo destruir ou inibir o crescimento das 
células neoplásicas. Para tal procedimento, pode-se utilizar várias vias de administração sendo as principais: endovenosa, via oral, intramuscular e subcutânea", certamente muitos não entenderiam. Por outro lado, seria melhor compreendido se escrito: "A quimioterapia é uma das formas de tratar o câncer que destrói ou impede o crescimento da doença. Ela pode ser feita na veia, por boca, no músculo e na gordura da pele".

Além de se preocupar com a extensão da frase, é necessário também atentar para a estrutura da mesma. A ordem direta, ou seja, o sujeito antes do predicado, a oração principal antes da oração subordinada, o principal antes do acessório, a causa antes do efeito, também facilitam a leitura. Isso acontece porque a memória retém com mais facilidade o que vem no começo da frase ${ }^{(32)}$.

Torna-se fundamental definir com clareza a quantidade de informação que vai ser transmitida, pois a mensagem pode ter formas diferentes na linguagem falada. A linguagem científica empregada no material escrito dificulta o entendimento do leitor; sendo assim, o texto escrito deve completar as mensagens expressas pela ilustração, deve ser breve, direto e apresentar uma linguagem correta e compreensível para o receptor da mensagem ${ }^{(6)}$.

Além do estabelecimento de alguns critérios para a elaboração do material escrito, se faz necessário também validar o seu conteúdo junto ao público para o qual foi desenvolvido. O enfermeiro amplia cada vez mais seu papel como educador, não só comunicando conteúdos em intervenções educativas, mas também avaliando os recursos educativos mediados pelos materiais educativos produzidos para consumo de seus educandos ${ }^{(6)}$.

O conceito de validade é abordado como sendo o grau em que um instrumento mostra-se apropriado para mensurar o que supostamente ele deveria medir. Assim, quando se submete um instrumento ao procedimento de validação, na realidade não é o instrumento em si que está sendo validado, mas sim o propósito pelo qual ele está sendo usado ${ }^{(33)}$.

A determinação da validade é facilitada quando múltiplas medidas são empregadas para responder a uma dada questão da pesquisa. A convergência de resultados, obtidos quando são usadas variadas técnicas, possibilita aumento da confiabilidade e validade dos achados do estudo e sua utilização na prática. Por isso, há várias maneiras de se verificar a validade de um instrumento ${ }^{(34)}$. 
$\mathrm{Na}$ qualificação do material, portanto, é necessário estar aberto a críticas e sugestões, para que o mesmo venha atender as necessidades daqueles que irão utilizá-lo, pois a premissa básica é que as pessoas possuem vivências e conhecimentos diferentes dos nossos.

Qualificar o conteúdo do manual com pacientes e familiares que já vivenciaram de alguma forma o tema nele abordado, é uma atitude necessária e um ganho importante para o pesquisador. É um momento em que nos damos conta do que realmente está faltando, do que não foi compreendido e da distância que existe entre o que escrevemos e o que é entendido e como é entendido; ou seja, das fantasias, dos tabus e dificuldades de ser paciente ou familiar e estar doente ${ }^{(5)}$.

Essas considerações justificam o interesse em desenvolver o estudo sobre a produção científica em materiais escritos impressos de orientação em Enfermagem, para a interpretação do conhecimento produzido na área com o propósito de auxiliar no desenvolvimento de futuras investigações.

Para investigar a contribuição de pesquisas realizadas sobre os materiais de orientação em Enfermagem, optou-se pelo método de revisão integrativa da literatura. Considerando-se o exposto no referencial teórico, definiu-se como problema de pesquisa: Qual conhecimento tem sido produzido sobre as características da comunicação dos materiais escritos impressos elaborados por enfermeiros brasileiros, que subsidiam as orientações em Enfermagem? 


\section{MÉTODO}

\subsection{TIPO DE ESTUDO}

Para investigar a contribuição de pesquisas realizadas sobre os materiais de orientação em Enfermagem, optou-se pelo método de revisão integrativa da literatura. É um método que se constitui basicamente em um instrumento da prática baseada em evidências (PEB), cuja abordagem é voltada ao cuidado clínico e ao ensino fundamentado no conhecimento e na qualidade da evidência ${ }^{(35)}$.

Um dos propósitos da PBE é encorajar a utilização de resultados de pesquisa junto à assistência à saúde prestada nos diversos níveis de atenção, reforçando a importância da pesquisa para a prática clínica ${ }^{(36)}$. Para a implementação desta abordagem na Enfermagem, o enfermeiro necessita saber como obter, interpretar e integrar as evidências com os dados clínicos e preferências do paciente na tomada de decisões para a assistência de Enfermagem aos pacientes e seus familiares ${ }^{(37)}$.

Envolve a definição do problema clínico, a identificação das informações necessárias, a condução da busca de estudos na literatura e sua avaliação crítica, a identificação da aplicabilidade dos dados oriundos das publicações e a determinação de sua utilização para o paciente ${ }^{(37)}$.

As iniciativas da PBE têm gerado um incremento na necessidade de produção de todos os tipos de revisões de literatura. Embora importantes, os métodos de revisão mais utilizados, a sistemática e a meta-análise, não contemplam importantes questões de Enfermagem relacionadas aos cuidados e/ou ao impacto da doença ou do tratamento $^{(35)}$. A revisão integrativa, nesse âmbito, em virtude de sua abordagem metodológica, permite a inclusão de métodos diversos, que têm o potencial de desempenhar um importante papel na PBE em Enfermagem ${ }^{(38)}$. Dessa forma, é fundamental diferenciá-la das linhas de estudos existentes.

A meta-análise é um método de revisão que combina as evidências de múltiplos estudos primários a partir do emprego de instrumentos estatísticos, a fim de aumentar a objetividade e a validade dos achados. O delineamento e as hipóteses dos estudos devem ser muito similares, se não idênticos ${ }^{(35)}$. $\mathrm{Na}$ abordagem da metaanálise, cada estudo é sintetizado, codificado e inserido em um banco de dados 
quantitativo. Subsequentemente, os resultados são transformados em uma medida comum para calcular a dimensão geral do efeito ou a intervenção mensurada ${ }^{(38)}$.

A revisão sistemática, por sua vez, é uma síntese rigorosa de todas as pesquisas relacionadas a uma questão específica, enfocando primordialmente estudos experimentais, comumente ensaios clínicos randomizados ${ }^{(35)}$. Difere-se de outros métodos de revisão, pois busca superar possíveis vieses em cada uma das etapas, seguindo um método rigoroso de busca e seleção de pesquisas, avaliação de relevância e validade dos estudos encontrados, coleta, síntese e interpretação dos dados oriundos de pesquisa ${ }^{(37)}$.

A revisão integrativa, finalmente, é a mais ampla abordagem metodológica referente às revisões, permitindo a inclusão de estudos experimentais e nãoexperimentais para uma compreensão completa do fenômeno analisado ${ }^{(35)}$. Combina também dados da literatura teórica e empírica, além de incorporar um vasto leque de propósitos: definição de conceitos, revisão de teorias e evidências e análise de problemas metodológicos de um tópico particular. A ampla amostra, em conjunto com a multiplicidade de propostas, deve gerar um panorama consistente e compreensível de conceitos complexos, teorias ou problemas de saúde relevantes para a Enfermagem ${ }^{(38)}$.

O processo de elaboração da revisão integrativa encontra-se bem definido na literatura; entretanto, diferentes autores adotam formas distintas de subdivisão de tal processo, com pequenas modificações ${ }^{(39)}$.

\subsection{PROCEDIMENTOS DE COLETA DE DADOS}

Para realização desse estudo seguimos as fases propostas da revisão integrativa sugeridas por Ganong ${ }^{(39)}$ que são:

\section{$1^{\text {a }}$ Fase: selecionar hipóteses ou questões para a revisão}

A definição da pergunta norteadora é a fase mais importante da revisão, pois determina quais serão os estudos incluídos, os meios adotados para a identificação e as informações coletadas de cada estudo selecionado. Logo, inclui a definição dos participantes, as intervenções a serem avaliadas e os resultados a serem 
mensurados ${ }^{(37)}$. Deve ser elaborada de forma clara e específica, e relacionada a um raciocínio teórico, incluindo teorias e raciocínios já aprendidos pelo pesquisador ${ }^{(40)}$; além disso, o tópico deve ser instigante e estimular a curiosidade do pesquisador ${ }^{(39)}$.

\section{$2^{\mathrm{a}}$ Fase: selecionar as pesquisas que irão compor a amostra}

Intrinsecamente relacionada à fase anterior, a busca em base de dados deve ser ampla e diversificada, contemplando a procura em bases eletrônicas, busca manual em periódicos, as referências descritas nos estudos selecionados, o contato com pesquisadores e a utilização de material não publicado ${ }^{(37)}$. Os critérios de amostragem precisam garantir a representatividade da amostra, sendo importantes indicadores da confiabilidade e da fidedignidade dos resultados. A conduta ideal é incluir todos os estudos encontrados ou a sua seleção randomizada; porém, se as duas possibilidades forem inviáveis pela quantidade de trabalhos, deve-se expor e discutir claramente os critérios de inclusão e exclusão de artigos. A omissão de procedimentos pode ser uma ameaça para a validade da revisão ${ }^{(39)}$. Desta forma, a determinação dos critérios deve ser realizada em concordância com a pergunta norteadora, considerando os participantes, a intervenção e os resultados de interesse $^{(35)}$.

\section{$3^{\mathrm{a}}$ Fase: definir as características da pesquisa}

Para extrair os dados dos artigos selecionados, faz-se necessária a utilização de um instrumento previamente elaborado capaz de assegurar que a totalidade dos dados relevantes seja extraída, minimizar o risco de erros na transcrição, garantir precisão na checagem das informações e servir como registro. Os dados devem incluir: definição dos sujeitos, metodologia, tamanho da amostra, mensuração de variáveis, método de análise e conceitos embasadores empregados ${ }^{(35)}$. Um dos modos mais simples e claros para apresentar características da pesquisa primária é a construção de tabelas. O uso de tabelas propiciaria um modo simples e claro de apresentar ao leitor uma grande quantidade de dados para uma avaliação sistemática, sumarização e discussão de achados relevantes, bem como das conclusões ${ }^{(39)}$. 


\section{$4^{\mathrm{a}}$ Fase: analisar os achados}

Análoga à análise dos dados das pesquisas convencionais, esta fase demanda uma abordagem organizada para ponderar o rigor e as características de cada estudo. A experiência clínica do pesquisador contribui na apuração da validade dos métodos

e dos resultados, além de auxiliar na determinação de sua utilidade na prática ${ }^{(40-41)}$.

A análise dos achados no processo de revisão integrativa é comparável ao exame de análise de dados primários, e consiste na análise dos resultados evidenciados dos artigos incluídos na revisão ${ }^{(39)}$.

\section{$5^{\text {a }}$ Fase: interpretar os resultados}

Esta etapa pode ser comparada à discussão de resultados dos estudos primários. O pesquisador apresenta e discute as evidências oriundas dos estudos incluídos naquelas geradas pela revisão integrativa. Ainda fará sugestões para a prática, bem como discutirá o impacto político ou prático e os resultados em relação às teorias e fará sugestões para pesquisas futuras ${ }^{(39)}$.

\section{$6^{\mathrm{a}}$ Fase: relatar a revisão}

A apresentação da revisão deve ser clara e completa para permitir ao leitor avaliar criticamente os resultados. Deve conter, então, informações pertinentes e detalhadas, baseadas em metodologias contextualizadas, sem omitir qualquer evidência relacionada prática ${ }^{(40-41)}$.

A proposta da revisão integrativa é reunir e sintetizar as evidências disponíveis na literatura, pois as conclusões podem ser questionadas caso a construção do trabalho seja baseada em uma metodologia questionável ${ }^{(39)}$. 


\subsubsection{Questão norteadora da revisão integrativa}

$\mathrm{Na}$ elaboração da questão norteadora de pesquisa, pode ser utilizada a estratégia PICO, que representa o acrônimo Patient, Intervention, Comparison and Outcomes (desfecho). A estratégia PICO é capaz de maximizar a recuperação de evidências nas bases de dados, focar o escopo da pesquisa e evitar a realização de buscas desnecessárias, podendo ser utilizada na construção de questões de pesquisa de naturezas diversas, como as oriundas da clínica, do gerenciamento de recursos humanos e materiais, da busca de instrumentos para avaliação de sintomas e outras. Atribui-se ao $\mathbf{P}$ um único paciente, um grupo de pacientes com uma condição particular ou um problema de saúde; ao I uma intervenção que pode ser terapêutica, preventiva, diagnóstica, prognóstica, administrativa ou relacionada a assuntos econômicos; ao $\mathbf{C}$ como sendo a intervenção padrão, a mais utilizada ou a nenhuma intervenção; e ao $\mathbf{O}$ o resultado esperado ${ }^{(42)}$.

Foi elaborada a questão norteadora da revisão integrativa empregando a estratégia PICO, conforme descrição no Quadro 1:

Quadro 1 - Descrição da estratégia PICO para elaboração da pergunta de pesquisa.

\begin{tabular}{|c|c|l|}
\hline Acrônimo & Definição & \multicolumn{1}{|c|}{ Descrição } \\
\hline P & Problema & $\begin{array}{l}\text { Educação em saúde utilizando os } \\
\text { materiais escritos impressos como } \\
\text { subsídio. }\end{array}$ \\
\hline I & Intervenção & $\begin{array}{l}\text { Artigos elaborados por enfermeiros } \\
\text { brasileiros sobre materiais escritos } \\
\text { impressos de orientação sem vínculo } \\
\text { com entidade }\end{array}$ \\
\hline C & Controle ou comparação & $\begin{array}{l}\text { governamental. } \\
\text { os itens relacionados às } \\
\text { coracterísticas da comunicação. }\end{array}$
\end{tabular}




\section{continuação}

Quadro 1 - Descrição da estratégia PICO para elaboração da pergunta de pesquisa.

\begin{tabular}{|l|l|l|}
\hline Outcomes & $\begin{array}{l}\text { Identificar a realidade brasileira sobre } \\
\text { (Desfecho/Resultado) } \\
\text { artigos científicos desenvolvidos por } \\
\text { enfermeiros brasileiros sobre as } \\
\text { características da comunicação dos } \\
\text { materiais escritos impressos, que } \\
\text { subsidiam as orientações em } \\
\text { Enfermagem. }\end{array}$ \\
\hline
\end{tabular}

conclusão

Assim, formulou-se a seguinte questão: Qual conhecimento tem sido produzido sobre as características da comunicação dos materiais escritos impressos elaborados por enfermeiros brasileiros, que subsidiam as orientações em Enfermagem?

\subsubsection{Procedimentos adotados para a busca e seleção dos artigos}

O levantamento bibliográfico foi realizado através da Internet, sem limite de período, no Portal BVS (Biblioteca Virtual em Saúde) e BVS temática em Enfermagem rastreando todas as bases de dados e utilizando todos os índices. Pela BVS e BVS Enfermagem é possível consultar simultaneamente várias bases de dados.

Além do Portal BVS e BVS Enfermagem, foi realizada busca manual nas dependências da Escola de Enfermagem da Universidade de São Paulo, na Biblioteca "Wanda de Aguiar Horta", dos resumos encontrados em busca eletrônica.

A fim de combinar os descritores nas diferentes estratégias de busca, foi utilizado o operador booleano AND, que é delimitador das bases de dados, sendo AND uma combinação restritiva.

Para a localização dos artigos, foram selecionadas palavras-chave relacionadas ao tema, tendo como base a estratégia PICO, conforme já mencionado, 
e os vocabulários controlados específicos da BIREME. Foram utilizados os seguintes descritores e suas combinações na língua portuguesa:

- “alfabetização em saúde” and enfermagem

- "comunicação em saúde" and enfermagem

- "materiais de ensino" and enfermagem

- "informação de saúde ao consumidor" and enfermagem

- manuais and enfermagem

- "educação em enfermagem" and manuais

- "prospecto para educação de pacientes"

- "serviço hospitalar de educação" and enfermagem

- "sistemas de comunicação no hospital" and enfermagem

Foi realizada também busca com palavras- chave/unitermos, ou seja, termos que não estão indexados no Descritor em ciências da saúde (DeCS), mas estão relacionados a materiais escritos. As palavras-chave/unitermos utilizados foram:

- cartilha

- "comunicação escrita" and enfermagem

- "impressos hospitalares"

- material and enfermagem

- manual and enfermagem

- "orientação escrita" and enfermagem

- folder and enfermagem.

Os descritores e as palavras-chave/unitermos utilizados foram escolhidos baseados na experiência em leituras prévias para a elaboração da monografia da autora.

Os critérios de inclusão definidos para a seleção dos artigos foram:

- Artigos em português;

- Artigos que retratassem a temática referente a materiais escritos;

- Artigos que tivessem como autor, pelo menos, um profissional enfermeiro. 
O critério de exclusão foi:

- Artigos cujos projetos estivessem vinculados a entidades governamentais, considerando que projetos com esse caráter, são amparados por uma grande estrutura profissional e financeira.

\subsubsection{Instrumento de Coleta de dados}

Para extrair os dados dos artigos selecionados, foi utilizado um instrumento previamente elaborado capaz de assegurar que a totalidade dos dados relevantes fosse extraída, minimizar o risco de erros na transcrição, garantir precisão na checagem das informações e servir como registro ${ }^{(35)}$.

As publicações foram examinadas utilizando-se de um instrumento construído para a presente pesquisa, que atende seus objetivos e contempla os seguintes dados (Apêndice 1):

1- Dados referentes ao tratamento de autores: titulação e profissão.

2- Dados referentes à publicação: ano de publicação, estado, cidade, base de dados, revista e se está relacionado à TCC, monografia, dissertações e teses.

3- Dados referentes ao artigo: objetivo geral e metodologia da pesquisa e se financiamento referido.

4- Dados referentes ao material escrito: público alvo, especialidade, local de uso do material, nome utilizado para o instrumento educativo, se o artigo apresenta descrição e preocupação com a elaboração do material, se faz referência a alguma abordagem pedagógica, se realiza validação do instrumento, se conclui efetividade do uso do material e se utiliza referência internacional relacionada à elaboração de materiais escritos impressos.

Para organização das informações, contidas nas publicações científicas encontradas, foi realizada a leitura dos trabalhos, identificando-se o objeto, os objetivos dos estudos, procedimentos metodológicos e os resultados. 


\subsection{AMOSTRAGEM DO ESTUDO}

$\mathrm{Na}$ revisão bibliográfica foram encontrados 46 artigos, sendo que 36 deles eram na íntegra e 10 eram resumos. Dos 36 foram selecionados 11 artigos e, dos 10 resumos 7 foram selecionados, somando uma total de 18 artigos.

A exclusão desses artigos ocorreu porque 16 deles se repetiam em mais de uma base de dados e nos outros, após leitura dos artigos na íntegra, verificou-se que não se adequavam aos critérios de inclusão do trabalho, por terem sido elaborados exclusivamente por outros profissionais que não eram enfermeiros, outros por abordarem sobre materiais escritos para uso dos profissionais da Enfermagem no do hospital, tais como manual de normas e procedimentos de Enfermagem. Além desses, dez trabalhos foram selecionados enquanto resumos, porém, ao ler o artigo na íntegra, verificou-se que 3 não se adequavam aos objetivos desse trabalho.

Além desses 18 artigos foram incluídos mais 4 que já eram conhecidos pela autora e não foram encontrados na revisão bibliográfica. A partir das análises dos títulos e dos resumos disponíveis, a amostra do trabalho utilizou um total de 22 publicações. Para ilustrar, segue a figura 2: 


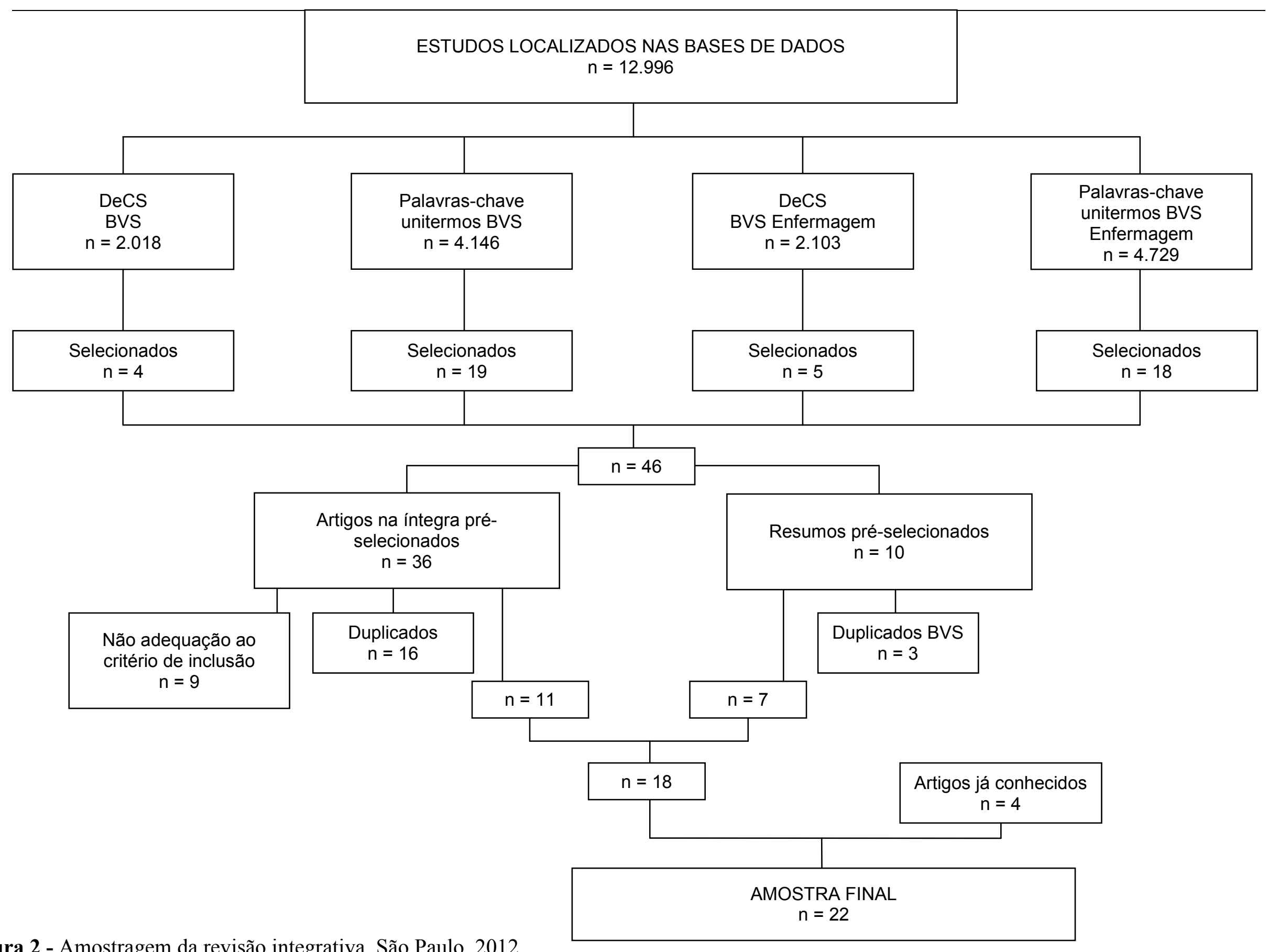

Figura 2 - Amostragem da revisão integrativa. São Paulo, 2012. 


\subsection{TRATAMENTO DOS DADOS}

Os dados foram descritos por meio de análise descritiva. 
5 RESULTADOS 


\section{RESULTADOS}

No quadro 2 são apresentados os dados relacionados aos 22 estudos em relação ao: número do estudo, título, periódico, autoria, ano, delineamento de pesquisa e bases de dados. Foram numerados de 1 a 22.

Quadro 2 - Publicações agrupadas quanto ao: número do estudo, título, periódico, autoria, ano, delineamento de pesquisa e bases de dados.

\begin{tabular}{|c|c|c|c|c|c|c|}
\hline $\begin{array}{l}\mathrm{N}^{\mathrm{o}} \text { do } \\
\text { estudo }\end{array}$ & Título & Periódico & Autores & Ano & $\begin{array}{l}\text { Delineamento } \\
\text { de pesquisa }\end{array}$ & $\begin{array}{c}\text { Bases de } \\
\text { Dados }\end{array}$ \\
\hline 1 & $\begin{array}{c}\text { Cartilha } \\
\text { educativa para } \\
\text { orientação } \\
\text { materna sobre os } \\
\text { cuidados com o } \\
\text { bebê prematuro. }\end{array}$ & $\begin{array}{c}\text { Revista } \\
\text { Latino- } \\
\text { Americana de } \\
\text { Enfermagem }\end{array}$ & $\begin{array}{l}\text { Fonseca } \\
\text { LMM, } \\
\text { Schochi } \\
\text { CGSS, } \\
\text { Rocha } \\
\text { SMM e } \\
\text { Leite AM }\end{array}$ & 2004 & Qualitativa & $\begin{array}{c}\text { Lilacs } \\
\text { ScieLo } \\
\text { Medline }\end{array}$ \\
\hline 2 & $\begin{array}{l}\text { Cartilha sobre } \\
\text { auto-exame } \\
\text { ocular para } \\
\text { portadores do } \\
\text { HIV/AIDS como } \\
\text { tecnologia } \\
\text { emancipatória: } \\
\text { relato de } \\
\text { experiência. }\end{array}$ & $\begin{array}{l}\text { Revista } \\
\text { Eletrônica de } \\
\text { Enfermagem }\end{array}$ & $\begin{array}{l}\text { Caetano JA, } \\
\text { Pagliuca } \\
\text { LMF }\end{array}$ & 2006 & Qualitativa & Lilacs \\
\hline 3 & $\begin{array}{c}\text { Educação em } \\
\text { saúde e família: o } \\
\text { cuidado ao } \\
\text { paciente, vítima } \\
\text { de acidente } \\
\text { vascular cerebral. }\end{array}$ & $\begin{array}{c}\text { Acta } \\
\text { Scientiarum. } \\
\text { Health } \\
\text { Science }\end{array}$ & $\begin{array}{l}\text { Chagas NR, } \\
\text { Monteiro } \\
\text { ARM }\end{array}$ & 2004 & Qualitativa & Lilacs \\
\hline 4 & $\begin{array}{l}\text { Instrumento } \\
\text { educativo sobre } \\
\text { alimentação de } \\
\text { lactentes: } \\
\text { baseado nas } \\
\text { necessidades de } \\
\text { conhecimento } \\
\text { das mães. }\end{array}$ & $\begin{array}{l}\text { Revista do } \\
\text { Instituto de } \\
\text { Ciências da } \\
\text { Saúde }\end{array}$ & $\begin{array}{l}\text { Valezin DF, } \\
\text { Ballestero } \\
\text { E, } \\
\text { Aparecido } \\
\text { JC, Ribeirto } \\
\text { JF, Marinho } \\
\text { PC de M, } \\
\text { Costa } \\
\text { LFVC }\end{array}$ & 2009 & Quantitativa & Lilacs \\
\hline
\end{tabular}




\section{continuação}

Quadro 2 - Publicações agrupadas quanto ao: número do estudo, título, periódico, autoria, ano, delineamento de pesquisa e bases de dados.

\begin{tabular}{|c|c|c|c|c|c|c|}
\hline 5 & $\begin{array}{c}\text { Manual } \\
\text { educativo para o } \\
\text { autocuidado da } \\
\text { mulher } \\
\text { mastectomizada: } \\
\text { um estudo de } \\
\text { validação. }\end{array}$ & $\begin{array}{l}\text { Revista Texto } \\
\text { \& Contexto } \\
\text { Enfermagem }\end{array}$ & $\begin{array}{l}\text { Oliveira MS } \\
\text { de, } \\
\text { Fernandes } \\
\text { AFC, } \\
\text { Sawada NO }\end{array}$ & 2008 & Qualitativa & $\begin{array}{l}\text { Lilacs } \\
\text { ScieLo }\end{array}$ \\
\hline 6 & $\begin{array}{l}\text { Percepções de } \\
\text { mães de } \\
\text { prematuros } \\
\text { acerca da } \\
\text { vivência em um } \\
\text { programa } \\
\text { educativo. }\end{array}$ & $\begin{array}{c}\text { Revista } \\
\text { Latino- } \\
\text { Americana de } \\
\text { Enfermagem }\end{array}$ & $\begin{array}{l}\text { Ferecini } \\
\text { GM, } \\
\text { Fonseca } \\
\text { LMM, Leite } \\
\text { AM, Dare } \\
\text { MF, Assis } \\
\text { CS, Scochi } \\
\text { CGS }\end{array}$ & 2009 & Qualitativa & Lilacs \\
\hline 7 & $\begin{array}{c}\text { Percepção de } \\
\text { mães sobre um } \\
\text { manual educativo } \\
\text { sobre } \\
\text { estimulação } \\
\text { visual da criança. }\end{array}$ & $\begin{array}{l}\text { Revista } \\
\text { Eletrônica de } \\
\text { Enfermagem }\end{array}$ & $\begin{array}{l}\text { Silva GRF } \\
\text { da, Cardoso } \\
\text { MVLML }\end{array}$ & 2009 & Qualitativa & $\begin{array}{l}\text { Lilacs } \\
\text { ScieLo }\end{array}$ \\
\hline 8 & $\begin{array}{c}\text { Programa } \\
\text { educativo em } \\
\text { esquistossomose: } \\
\text { modelo de } \\
\text { abordagem } \\
\text { metodológica. }\end{array}$ & $\begin{array}{l}\text { Revista de } \\
\text { Saúde } \\
\text { Pública }\end{array}$ & $\begin{array}{l}\text { Ribeiro P de } \\
\text { J, Aguiar } \\
\text { LAK de, } \\
\text { Toledo CF } \\
\text { de, Barros } \\
\text { SM de O, } \\
\text { Borges DR }\end{array}$ & 2004 & Quantitativa & Lilacs \\
\hline 9 & $\begin{array}{c}\text { Tecnologia do } \\
\text { cuidado ao } \\
\text { paciente renal } \\
\text { crônico: enfoque } \\
\text { educativo- } \\
\text { terapêutico a } \\
\text { partir das } \\
\text { necessidades dos } \\
\text { sujeitos. }\end{array}$ & $\begin{array}{l}\text { Revista Texto } \\
\text { \& Contexto } \\
\text { Enfermagem }\end{array}$ & $\begin{array}{l}\text { Queiroz } \\
\text { MVO, } \\
\text { Dantas MC } \\
\text { de } \quad \text { Q, } \\
\text { Ramos IC, } \\
\text { Joreg MSBJ }\end{array}$ & 2008 & Qualitativa & $\begin{array}{l}\text { Lilacs } \\
\text { ScieLo }\end{array}$ \\
\hline
\end{tabular}




\section{continuação}

Quadro 2 - Publicações agrupadas quanto ao: número do estudo, título, periódico, autoria, ano, delineamento de pesquisa e bases de dados.

\begin{tabular}{|c|c|c|c|c|c|c|}
\hline 10 & $\begin{array}{c}\text { Validação de } \\
\text { material } \\
\text { informativo a } \\
\text { pacientes em } \\
\text { tratamento } \\
\text { quimioterápico e } \\
\text { aos seus } \\
\text { familiares. }\end{array}$ & $\begin{array}{l}\text { Revista da } \\
\text { Escola de } \\
\text { Enfermagem } \\
\text { da USP }\end{array}$ & $\begin{array}{l}\text { Salles PSS, } \\
\text { Castro } \\
\text { RCBR }\end{array}$ & 2010 & Quantitativa & $\begin{array}{c}\text { Lilacs } \\
\text { ScieLo } \\
\text { Medline }\end{array}$ \\
\hline 11 & $\begin{array}{c}\text { Autocuidado } \\
\text { para a } \\
\text { cicatrização da } \\
\text { ferida de colo de } \\
\text { útero. }\end{array}$ & $\begin{array}{c}\text { Revista } \\
\text { Enfermagem } \\
\text { UERJ }\end{array}$ & $\begin{array}{l}\text { Menezes } \\
\text { AF de, } \\
\text { Castro MA } \\
\text { de, } \\
\text { Diogenes } \\
\text { MAR }\end{array}$ & 2006 & Qualitativa & $\begin{array}{l}\text { Lilacs } \\
\text { Medline }\end{array}$ \\
\hline 12 & $\begin{array}{l}\text { Cartilha sobre } \\
\text { saúde sexual e } \\
\text { reprodutiva para } \\
\text { surdos como } \\
\text { tecnologia } \\
\text { emancipadora: } \\
\text { relato de } \\
\text { experiência. }\end{array}$ & $\begin{array}{l}\text { Revista da } \\
\text { Rede de } \\
\text { Enfermagem } \\
\text { do Nordeste }\end{array}$ & $\begin{array}{l}\text { Sousa RA } \\
\text { de, } \\
\text { Pagliuca } \\
\text { LMF }\end{array}$ & 2001 & $\begin{array}{l}\text { Relato de } \\
\text { experiência }\end{array}$ & Lilacs \\
\hline 13 & $\begin{array}{l}\text { Impacto de um } \\
\text { manual } \\
\text { instrucional } \\
\text { sobre o } \\
\text { aleitamento } \\
\text { materno de } \\
\text { recém-nascidos } \\
\text { pré-termos em } \\
\text { Unidade de } \\
\text { Terapia Intensiva } \\
\text { Neonatal. }\end{array}$ & $\begin{array}{c}\text { Pediatria } \\
\text { (São Paulo) }\end{array}$ & $\begin{array}{l}\text { Matuhara } \\
\text { AM, } \\
\text { Naganuma } \\
\text { M }\end{array}$ & 2006 & Quantitativa & Lilacs \\
\hline 14 & $\begin{array}{c}\text { Manual de } \\
\text { orientaçäo a } \\
\text { pacientes } \\
\text { portadores de } \\
\text { diabetes mellitus. }\end{array}$ & $\begin{array}{c}\text { Revista } \\
\text { Gaúcha de } \\
\text { Enfermagem }\end{array}$ & $\begin{array}{l}\text { Volpatto A, } \\
\text { Preussler G, } \\
\text { Motta MA, } \\
\text { Varianni R, } \\
\text { Bercini R }\end{array}$ & 1986 & $\begin{array}{l}\text { Relato de } \\
\text { experiência }\end{array}$ & Lilacs \\
\hline
\end{tabular}




\section{continuação}

Quadro 2 - Publicações agrupadas quanto ao: número do estudo, título, periódico, autoria, ano, delineamento de pesquisa e bases de dados.

\begin{tabular}{|c|c|c|c|c|c|c|}
\hline 15 & $\begin{array}{l}\text { Manual de } \\
\text { orientação para } \\
\text { paciente } \\
\text { infartado. }\end{array}$ & $\begin{array}{l}\text { Revista } \\
\text { Brasileira de } \\
\text { Enfermagem }\end{array}$ & $\begin{array}{l}\text { Marino } \\
\text { MMF de, } \\
\text { Suedekum } \\
\text { EWM, } \\
\text { Cassol MJ, } \\
\text { Iza MM }\end{array}$ & 1994 & Quantitativa & Lilacs \\
\hline 16 & $\begin{array}{c}\text { Manual de } \\
\text { orientação sexual } \\
\text { para o lesado } \\
\text { medular: } \\
\text { metodologia de } \\
\text { aplicaçäo e } \\
\text { resultados. }\end{array}$ & $\begin{array}{l}\text { Revista } \\
\text { Brasileira de } \\
\text { Enfermagem }\end{array}$ & $\begin{array}{l}\text { Ferolla EC, } \\
\text { Lourenço C }\end{array}$ & 1996 & Quantitativa & $\begin{array}{l}\text { Lilacs } \\
\text { Medline }\end{array}$ \\
\hline 17 & $\begin{array}{c}\text { Orientações a } \\
\text { familiares de } \\
\text { pacientes de um } \\
\text { Centro de } \\
\text { Tratamento } \\
\text { Intensivo: relato } \\
\text { de experiência. }\end{array}$ & $\begin{array}{c}\text { Rev. HCPA } \\
\text { da Faculdade } \\
\text { de Medicina } \\
\text { da } \\
\text { Universidade } \\
\text { Federal do } \\
\text { Rio Grande } \\
\text { do Sul }\end{array}$ & $\begin{array}{l}\text { Echer IC, } \\
\text { Onzi MR, } \\
\text { Tomasi } \\
\text { TMM, } \\
\text { Bruxel VM }\end{array}$ & 1996 & $\begin{array}{l}\text { Relato de } \\
\text { experiência }\end{array}$ & Lilacs \\
\hline 18 & $\begin{array}{l}\text { Crianças/Adolesc } \\
\text { entes em } \\
\text { quimioterapia } \\
\text { ambulatorial: } \\
\text { Implicações para } \\
\text { a enfermagem. }\end{array}$ & $\begin{array}{c}\text { Revista } \\
\text { Latino- } \\
\text { Americana de } \\
\text { Enfermagem }\end{array}$ & $\begin{array}{l}\text { Costa JC } \\
\text { de, Lima } \\
\text { RAG de }\end{array}$ & 2002 & Qualitativa & $\begin{array}{c}\text { Lilacs } \\
\text { ScieLo } \\
\text { Medline }\end{array}$ \\
\hline 19 & $\begin{array}{c}\text { Manual } \\
\text { Instrucional para } \\
\text { aleitamento } \\
\text { materno de } \\
\text { recém-nascidos } \\
\text { pré termo. }\end{array}$ & $\begin{array}{c}\text { Pediatria } \\
\text { (São Paulo) }\end{array}$ & $\begin{array}{l}\text { Matuhara } \\
\text { AM, } \\
\text { Naganuma } \\
\text { M }\end{array}$ & 2006 & $\begin{array}{l}\text { Relato de } \\
\text { experiência }\end{array}$ & Lilacs \\
\hline 20 & $\begin{array}{c}\text { O cuidado à } \\
\text { pessoa } \\
\text { traqueostomizada } \\
\text { : Análise de um } \\
\text { folheto } \\
\text { educativo. }\end{array}$ & $\begin{array}{l}\text { Revista de } \\
\text { Enferm } \\
\text { Escola Anna } \\
\text { Nery }\end{array}$ & $\begin{array}{l}\text { Freitas AA } \\
\text { de } \quad S, \\
\text { Cabral IE }\end{array}$ & 2008 & Qualitativa & $\begin{array}{l}\text { Lilacs } \\
\text { ScieLo }\end{array}$ \\
\hline
\end{tabular}




\section{continuação}

Quadro 2 - Publicações agrupadas quanto ao: número do estudo, título, periódico, autoria, ano, delineamento de pesquisa e bases de dados.

\begin{tabular}{|c|c|c|l|c|c|c|}
\hline 21 & $\begin{array}{c}\text { O método arco } \\
\text { no ensino pré- } \\
\text { operatório de } \\
\text { pacientes } \\
\text { laringectomizado } \\
\text { s. }\end{array}$ & $\begin{array}{c}\text { Revista } \\
\text { Brasileira de } \\
\text { Cancerologia }\end{array}$ & $\begin{array}{l}\text { Snobe HM, } \\
\text { Hayashida } \\
\text { M, Mendes } \\
\text { IAC, Zago } \\
\text { MMF }\end{array}$ & Qualitativa & Lilacs \\
\hline $\mathbf{2 2}$ & $\begin{array}{c}\text { O processo de } \\
\text { elaboração de } \\
\text { cartilhas para } \\
\text { orientação do } \\
\text { autocuidado no } \\
\text { programa } \\
\text { educativo em } \\
\text { Diabetes. }\end{array}$ & $\begin{array}{c}\text { Brasileira de } \\
\text { Enfermagem }\end{array}$ & $\begin{array}{l}\text { Revista } \\
\text { Candido } \\
\text { NA, HC, } \\
\text { Alexandre } \\
\text { LR, Pereira } \\
\text { FL }\end{array}$ & 2009 & $\begin{array}{c}\text { Relato de } \\
\text { experiência }\end{array}$ & $\begin{array}{c}\text { Lilacs } \\
\text { ScieLo } \\
\text { Medline }\end{array}$ \\
& & & & \\
\end{tabular}

conclusão

Para a localização dos artigos, foram selecionados descritores e palavraschave relacionadas ao tema, tendo como base a estratégia PICO, conforme já mencionado. Na tabela 1 verifica-se que por associação de descritores e um descritor no portal BVS, por meio do método integrado, foram encontrados 2018 artigos. Lendo-se e analisando-se os resumos encontrados, apenas 4 artigos foram selecionados por se adequarem à questão direcionadora da revisão.

Tabela 1 - Total de artigos encontrados por descritores em ciências da saúde (DeCS) no portal BVS em 2012.

\section{Descritores em ciências da saúde (DeCS)}

\author{
Artigos \\ pesquisados
}

\author{
Artigos \\ selecionados
}

alfabetização em saúde and

enfermagem

comunicação em saúde and enfermagem 


\section{continuação}

Tabela 1 - Total de artigos encontrados por descritores em ciências da saúde (DeCS) no portal BVS em 2012.

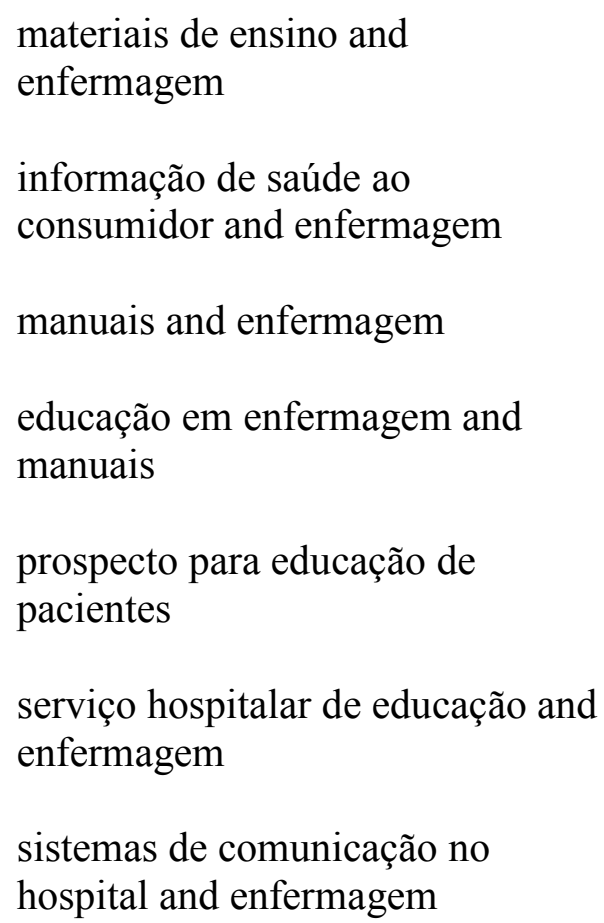

1154

27

2

93

6

30

205

2

(1)

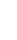

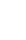

\section{Total}

A tabela 2 demonstra que por associação de 3 palavras-chave/unitermos e 4 palavras- chave/unitermos com o descritor enfermagem no portal BVS, por meio do método integrado, foram encontrados 4146 artigos. Dos resumos lidos e analisados, 19 artigos foram selecionados por preencherem os critérios de inclusão. 
Tabela 2 - Total de artigos encontrados por palavras-chave/unitermos no portal BVS em 2012.

\begin{tabular}{lcc}
\hline \multicolumn{1}{c}{$\begin{array}{c}\text { Palavras-Chave } \\
\text { Unitermos } \\
\text { BVS }\end{array}$} & $\begin{array}{c}\text { Artigos } \\
\text { pesquisados }\end{array}$ & $\begin{array}{c}\text { Artigos } \\
\text { selecionados }\end{array}$ \\
\hline cartilha & 168 & 6 \\
comunicação escrita and enfermagem & 19 & - \\
impressos hospitalares & 4 & - \\
material and enfermagem & 2821 & 5 \\
manual and enfermagem & 1123 & - \\
orientação escrita and enfermagem & - & - \\
folder and enfermagem & 11 & $\mathbf{1 9}$ \\
\hline & & \\
\hline
\end{tabular}

conclusão

Já a tabela 3 indica que quando se associa os 8 descritores com a palavra enfermagem e o descritor prospecto para educação de pacientes, por meio do método integrado, no portal BVS Enfermagem, encontramos 2103 artigos. Após leitura criteriosa dos resumos encontrados, apenas 5 artigos foram selecionados.

Tabela 3 - Total de artigos encontrados por descritores em ciências da saúde (DeCS) no portal BVS Enfermagem em 2012.

\begin{tabular}{ccc}
\hline $\begin{array}{c}\text { Descritores } \\
\text { BVS Enfermagem }\end{array}$ & $\begin{array}{c}\text { Artigos } \\
\text { pesquisados }\end{array}$ & $\begin{array}{c}\text { Artigos } \\
\text { selecionados }\end{array}$ \\
\hline alfabetização em saúde and enfermagem & 41 & - \\
comunicação em saúde and enfermagem & 19 & - \\
materiais de ensino and enfermagem & 1170 & 3
\end{tabular}




\section{continuação}

Tabela 3 - Total de artigos encontrados por descritores em ciências da saúde (DeCS) no portal BVS Enfermagem em 2012.

informação de saúde ao consumidor and enfermagem

manuais and enfermagem

educação em enfermagem and manuais

prospecto para educação de pacientes

serviço hospitalar de educação and enfermagem

sistemas de comunicação no hospital and enfermagem
27

492

100

6

30

218
2

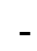

5
Total

2103 conclusão

A tabela 4 mostra que por associação de 3 palavras-chave/unitermos e 4 palavras- chave/unitermos com o descritor enfermagem no portal BVS Enfermagem, por meio do método integrado, foram encontrados 4729 artigos. Após a leitura e análise dos resumos 18 artigos fizeram parte da amostra por preencherem os critérios de inclusão.

Tabela 4 - Total de artigos encontrados por palavras-chave/unitermos no portal BVS Enfermagem em 2012.

\section{Palavras-Chave \\ Unitermos \\ BVS Enfermagem}

$\begin{array}{cc}\text { Artigos } & \text { Artigos } \\ \text { pesquisados } & \text { selecionados }\end{array}$

225 cartilha 


\section{continuação}

Tabela 4 - Total de artigos encontrados por palavras-chave/unitermos no portal BVS Enfermagem em 2012.

comunicação escrita and enfermagem

impressos hospitalares

material and enfermagem

manual and enfermagem

orientação escrita and enfermagem

folder and enfermagem
39

6

3210

1233

16

4729
18

conclusão

Dos artigos encontrados, alguns foram excluídos por serem elaborados por outros profissionais, outros por abordarem sobre materiais escritos para uso dos profissionais da Enfermagem do hospital, tais como manual de normas e procedimentos de Enfermagem. Além desses, dez trabalhos foram selecionados enquanto resumos, porém, ao ler o artigo na íntegra, verificou-se que 3 não se adequavam aos objetivos desse trabalho.

Dos artigos selecionados para amostras, conforme explicitado na página 52, alguns se repetiam por estarem indexados em mais de uma base de dados, o que reduziu de 46 para 18 o número de artigos da amostra.

Além desses 18 artigos foram incluídos mais 4 que já eram conhecidos pela autora e não foram encontrados na revisão bibliográfica. A partir das análises dos títulos e dos resumos disponíveis foi incluído na pesquisa um total de 22 publicações.

No quadro 1, do número 1 ao 18 são artigos encontrados na revisão bibliográfica, e do número 19 a 22 são artigos conhecidos pela autora previamente. 
Após a seleção dos trabalhos científicos, foi realizada leitura criteriosa de todos os trabalhos científicos na íntegra, com a aplicação do instrumento de coleta de dados.

\subsection{CARACTERIZAÇÃO DOS ESTUDOS SELECIONADOS}

A seguir, a caracterização dos 22 trabalhos científicos que constituíram a amostra do nosso estudo.

Do total dos $71(100,0 \%)$ autores, quanto à titulação, tivemos $23(32,3 \%)$ doutores, seguidos de $10(14,0 \%)$ discentes e igualmente $10(14,0 \%)$ graduados e 11 $(15,4 \%)$ mestres. Obtivemos ainda $7(9,8 \%)$ pós-doutores, $6(8,4 \%)$ especialistas, 3 $(4,2 \%)$ doutorandos e $1(1,4 \%)$ cuja titulação não foi informada e nem encontrada pela autora em busca eletrônica.

Ainda caracterizando os autores, constamos que das $62(100,0 \%)$ eventos relacionados às profissões, a maioria dos autores é docente representando 34 (54,8\%), sendo que 32 são docentes de enfermagem e 2 docentes na área médica. Os enfermeiros também apresentam um percentual de destaque em relação às demais profissões, com 21 (33,8\%). Encontramos ainda 3 (4,8\%) médicos, 2 (3,2\%) supervisores/coordenadores, 1 (1,6\%) especialista em laboratório e, igualmente, 1 $(1,6 \%)$ que não informou a profissão e que não foi encontrada pela autora em busca eletrônica.

$\mathrm{Na}$ caracterização dos autores, tanto na titulação quanto na profissão, alguns artigos não continham informações quanto à titulação e a profissão dos autores, sendo necessária então busca dessas informações na internet e nos currículos lattes dos autores.

Das 12 instituições encontradas, $6(50,0 \%)$ são instituições na região Sudeste, $4(33,0 \%)$ são na região Nordeste e $2(12,0 \%)$ na região Sul. Dessas instituições 7 $(58,0 \%)$ são federais, $3(25,0 \%)$ são particulares e $2(17,0 \%)$ são instituições estaduais.

Com relação aos profissionais que são enfermeiros assistenciais, 13 (61,9\%) trabalham em hospitais, $4(19,0 \%)$ não informaram o local de trabalho, 2 (9,5\%) trabalham em secretaria de saúde, 1 (4,7\%) em ambulatório e 1 (4,7\%) em PSF. 
Quanto ao ano de publicação, dos artigos 22 (100,0\%) selecionados, verificamos que houve maior produção na década de 2000, ou seja, nos últimos 10 anos, representando $18(81,8 \%)$ dos artigos. Destacamos o ano de 2006, que apresentou $4(18,1 \%)$ das publicações, seguidas de $3(13,6 \%)$ no ano de 2004 . Na década de 90 encontramos 4 (18,1\%) publicações, com destaque no ano de 1996 onde foram selecionados $2(9,0 \%)$ artigos.

Publicações no estado de São Paulo totalizaram 11 (50,0\%) amostras, o segundo lugar em publicações foi o estado do Ceará com 6 (27,2\%), o terceiro foi o estado do Rio Grande do Sul com 2 (9,0\%) e por último os estados de Minas Gerais, Rio Grande do Norte e Rio de Janeiro com 1 (4,5\%) cada. Ao analisarmos as publicações por cidade, destacamos o número de publicações de Fortaleza 6 (27,2\%) seguido da cidade de Ribeirão Preto, com 4 (18,1\%). Em terceiro lugar encontramos Campinas e Porto Alegre com $2(9,0 \%)$ cada seguidas das cidades de Belo Horizonte, Jundiaí, Mossoró e Rio de Janeiro com 1 (4,5\%) cada.

Observou-se também, a partir do levantamento bibliográfico que, entre as fontes utilizadas, a que recuperou o maior número de artigos foi a Lilacs, com 22 (61,1\%), seguida do Scielo, com 8 (22,2\%), e Medline com 6 (16,6\%). Alguns artigos foram encontrados em mais de uma base de dados.

Os periódicos de publicação desses trabalhos foram diversos, e estão demonstrados na tabela 5 .

Tabela 5 - Estudos selecionados de acordo com as revistas de publicação, frequência e percentuais. 2012

Revistas $\quad$ Frequência $\quad$ Percentual \%

$\begin{array}{lcc}\text { Rev. Brasileira de Enf. Brasília } & 2 & 9,0 \\ \text { Rev. Eletrônica de Enf. } & 2 & 9,0 \\ \text { Rev. Latino-am Enf } & 2 & 9,0 \\ \text { Revista de Pediatria } & 2 & 9,0 \\ \text { Texto Contexto Enf } & 2 & 9,0\end{array}$




\section{continuação}

Tabela 5 - Estudos selecionados de acordo com as revistas de publicação, frequência e percentuais. 2012

Acta Paulista Enf.

Acta Scientiarum Health Scienes

Esc. Anna Nery Rev. Enfermagem

Rev. Brasileira de Cancerologia

Rev. Enf. UERJ

Rev. Escola Enf USP

Rev. Gaúcha de Enfermagem

Rev. HCPA

Rev. Inst. Ciênc. Saúde

Revista Brasileira de Enfermagem

Revista de Saúde Pública

Revista Rene
1

1

1

1

1

1

1

1

1

1

1

1
4,5

4,5

4,5

4,5

4,5

4,5

4,5

4,5

4,5

4,5

4,5

4,5

Total

100,0

conclusão

O tipo de publicação predominante foi em forma de pesquisa regular com 11 $(50,0 \%)$, dissertação $6(27,2 \%)$, TCC $2(9,0 \%)$, tese $2(9,0 \%)$ e monografia $1(4,5 \%)$. Encontramos em um trabalho a utilização do termo tese referindo-se a uma dissertação de mestrado. Esses são termos conceituais de definições distintas e foram utilizados de maneira inadequada.

Observou-se a partir do levantamento bibliográfico, conforme tabela 6, que quanto aos objetivos dos artigos: o dado que apresentou a maior frequência foi relatar processo de elaboração do material, com 7 (32,0\%); seguido do objetivo de relatar 
sobre um projeto educativo no qual o material é uma das estratégias de ensino, 3 $(14,0 \%)$.

Tabela 6 - Estudos selecionados de acordo com os objetivos dos artigos selecionados, frequência e percentuais. 2012

\section{Objetivo do artigo}

Frequência

Relatar sobre um projeto educativo no qual o material é uma das estratégias de ensino

Analisar o material

Identificar conhecimento do público e elaborar manual

Validar material

Analisar dificuldades enfrentadas pelos pais em domicílio quando realizam QT e citar a elaboração do material

Desenvolver e avaliar ações onde o material foi utilizado como instrumento educativo

Identificar fatores que interferem na realização do autocuidado e relatar produção do material

Investigar percepção sobre o tema e avaliar o material

Relatar assistência de enfermagem e apresentar o material

Verificar impacto da aplicação do material
7

3

32,0

14,0

2

9,0

2

9,0

2

9,0

1

5,0

1

5,0

1

5,0

1

5,0

1

5,0

1

5,0 
Quanto aos delineamentos de pesquisa, identificamos que $11(50,0 \%)$ são estudos qualitativos, $6(27,0 \%)$ são estudos quantitativos, e os estudos caracterizados como relato de experiência representam $5(22,7 \%)$ deles.

Ao pesquisar sobre o tipo de financiamento referido, descobrimos que dos 22 (100,0\%) artigos $15(68,0 \%)$ não receberam auxílio financeiro e apenas 7 (32,0\%) recebem algum auxílio. Das entidades financiadoras destacamos o $\mathrm{CNPq}$ com 4 $(57,0 \%)$ dos financiamentos referidos em seguida estão a CAPES, FIPE e FUNCAP com $1(14,0 \%)$ cada uma delas.

Na tabela 7 nota-se que entre público-alvo - pacientes, 11 (79,0\%), deles são adultos. Em 1 artigo os destinatários eram crianças e adolescentes. Chamou-nos a atenção não haver nenhum material destinado a idosos, visto que tem ocorrido aumento na expectativa de vida e, consequentemente, aumento no número de idosos.

Tabela 7 - Distribuição das publicações localizadas segundo público alvo pacientes, frequência e percentuais. 2012

$\begin{array}{lll}\begin{array}{l}\text { Público alvo } \\ \text { Pacientes }\end{array} & \text { Frequência } & \text { Percentual \% }\end{array}$

\begin{tabular}{|c|c|c|}
\hline Adultos & 11 & 79,0 \\
\hline Adolescentes & 1 & 7,0 \\
\hline Crianças & 1 & 7,0 \\
\hline Público geral & 1 & 7,0 \\
\hline Total & 14 & 100,0 \\
\hline
\end{tabular}

A tabela 8 expressa que entre público-alvo - acompanhantes $6(43,0 \%)$ são acompanhantes de neonatos, seguidos de 4 (29,0\%) acompanhantes de adultos, 2 (14,0\%) acompanhantes de crianças e 2 (14,0\%) acompanhantes de adolescentes. Em 1 artigo os destinatários do material escrito eram crianças e adolescentes e seus familiares. Em outro os destinatários eram crianças e adolescentes. Constamos ainda 
que em 2 artigos o público-alvo constituía-se de adultos e de acompanhantes de adultos.

Tabela 8 - Distribuição das publicações localizadas segundo público alvo acompanhantes, frequência e percentuais. 2012

$\begin{array}{ccc}\text { Público alvo } & \text { Frequência } & \text { Percentual \% } \\ \text { Familiares e acompanhantes } & & \end{array}$

Neonatos

6

43,0

Adultos

4

29,0

Crianças

2

14,0

Adolescentes
14,0

Total 14

100,0

conclusão

Constamos em nossa pesquisa uma diversidade de especialidades encontradas. Entre elas as que se destacam são: neonatologia e oncologia representando $4(18,0 \%)$ cada uma delas, conforme demonstra a tabela 9. O tratamento oncológico tem sido realizado cada vez mais nos ambulatórios, ou seja, o paciente recebe a quimioterapia e vai para seu domicílio, onde frequentemente ocorrem os efeitos colaterais. Sendo assim, pacientes e familiares precisam estar cada vez mais orientados para que saibam manejar esses sintomas.

Tabela 9 - Distribuição das publicações localizadas segundo especialidades frequência e percentuais. 2012
Especialidade
Frequência
Percentual \%

Oncologia

4

18,0

continua 


\section{continuação}

Tabela 9 - Distribuição das publicações localizadas segundo especialidades frequência e percentuais. 2012

$\begin{array}{lcc}\text { Neonatologia } & 4 & 18,0 \\ \text { Endocrinologia } & 2 & 9,0 \\ \text { Neurologia } & 2 & 9,0 \\ \text { Oftalmologia } & 2 & 9,0 \\ \text { Cardiologia } & 1 & 5,0 \\ \text { Clínica médica } & 1 & 5,0 \\ \text { Ginecologia } & 1 & 5,0 \\ \text { Nefrologia } & 1 & 5,0 \\ \text { Otorrinolaringologia } & 1 & 5,0 \\ \text { Pediatria } & 1 & 5,0 \\ \text { Saúde Pública } & 1 & 5,0 \\ \text { UTI } & 1 & 5,0\end{array}$

Total

22

100,0

conclusão

Quanto ao local onde o material escrito é utilizado destacam-se os hospitais e ambulatórios, com $9(41,0 \%)$ cada um deles, seguidos de $3(14,0 \%)$ que não citaram os locais onde os materiais seriam utilizados e $1(5,0 \%)$ utilizado na UBS. Os locais mais citados contemplam o nível terciário de atenção em saúde, o que nos leva a refletir que as práticas ainda estão voltadas para a cura de doenças e reabilitação e não focalizam a prevenção e promoção da saúde.

Em relação ao nome utilizado para o material escrito, destacamos que o mais frequente foi cartilha, com 6 (27,0\%); manual de orientação, com 3 (14,0\%); e manual e manual instrucional, com $2(9,0 \%)$ cada um deles, conforme demonstra a 
Tabela 10. Ressaltamos que os nomes selecionados dados aos materiais escritos foram mantidos de acordo com o título e o termo utilizado no resumo de cada artigo.

Tabela 10 - Distribuição das publicações localizadas segundo nome utilizado para o material escrito, frequência e percentuais. 2012

$\begin{array}{ccc}\text { Nome utilizado para o material } & \text { Frequência } & \text { Percentual \% } \\ \text { escrito } & \end{array}$

\begin{tabular}{|c|c|c|}
\hline Cartilha & 6 & 27,0 \\
\hline Manual de orientação & 3 & 14,0 \\
\hline Manual instrucional & 2 & 9,0 \\
\hline Manual & 2 & 9,0 \\
\hline Cartilha de orientação & 1 & 5,0 \\
\hline Folder & 1 & 5,0 \\
\hline Folheto de orientação & 1 & 5,0 \\
\hline Folheto educativo & 1 & 5,0 \\
\hline Instrumento educativo & 1 & 5,0 \\
\hline Manual ilustrado & 1 & 5,0 \\
\hline Material didático instrucional & 1 & 5,0 \\
\hline Material informativo & 1 & 5,0 \\
\hline Material instrucional & 1 & 5,0 \\
\hline Total & 22 & 100,0 \\
\hline
\end{tabular}

Os dados demonstraram que dos $22(100,0 \%)$ artigos $15(68,0 \%)$ apresentam descrição do material e 7 (32,0\%) não apresentam descrição do material. Considerouse descrição quando o artigo citava o conteúdo e/ou os tópicos abordados nos materiais escritos já elaborados. 
Observou-se, a partir do levantamento bibliográfico, que dos $22(100,0 \%)$ artigos, 15 (68,0\%) apresentavam preocupação com a elaboração do material escrito e que os demais, $7(32,0 \%)$ dos artigos, não se aplicavam a este conceito. Isso foi considerado, pois o objetivo desses artigos não era elaborar materiais de orientação.

Dos artigos que apresentaram preocupação com a elaboração do material, constatou-se que os aspectos relevantes foram conteúdo, com 12 (26,0\%); figuras/ilustrações, com 9 (20,0\%); colaboração do público-alvo, com 8 (17,0\%); linguagem e colaboração de outros profissionais; com $6(13,0 \%)$ cada item; seguidos de estrutura do texto, com 3 (7,0\%); e layout, com 2 (4,0\%). Em alguns artigos mais de um aspecto foi considerado na elaboração do material.

Pesquisamos também qual profissional apresenta-se como consultor na elaboração do material escrito e encontramos um total de 8 eventos $(100,0 \%)$ dos quais o que apresenta maior frequência é a equipe multidisciplinar com 3 (38,0\%), os outros profissionais se dividem em $1(13,0 \%)$ em técnico em tratamento de imagem, técnico em audiovisual, psicologia, artista plástico e médico.

Quando pesquisamos de que maneira o público-alvo colabora, encontramos 3 (38,0\%) entrevistas, sendo que 2 delas são entrevistas semiestruturadas, 3 (38,0\%) grupos, sendo que um deles utilizou a filmagem como recurso e outro grupo focal. Encontramos ainda $1(13,0 \%)$ círculo de discussão e 1 (13,0\%) questionário.

Em relação aos trabalhos que faziam referência a alguma abordagem pedagógica, dos $22(100,0 \%)$ artigos, $17(77,0 \%)$ não faziam referência e apenas 5 $(23,0 \%)$ faziam referência a alguma abordagem pedagógica. Esses cinco artigos citam como referencial teórico Paulo Freire e sua Teoria da Problematização.

Analisamos também se os artigos realizavam avaliação do material escrito. Como resultado, obtivemos que $10(45,0 \%)$ dos artigos realizavam avaliação do material escrito e em $12(55,0 \%)$ não se aplicava essa questão, pois os objetivos dos artigos foram variados, como descritos anteriormente, o que poderia fornecer um falso dado se considerarmos que a avaliação do instrumento não foi realizada.

Ainda quanto à avaliação do material, verificamos de que maneira essa avaliação foi realizada e dividimos em dois grupos: quando os pacientes avaliam e quando os profissionais avaliam. Quando os pacientes avaliam o material, 4 (40,0\%) o fazem com questionário semiestruturado, $3(30,0 \%)$ o fazem com grupos, sendo eles: grupo focal, análise semântica e análise de termos técnico e $1(10,0 \%)$ das 
avaliações é feita com entrevista semiestruturada. Entre os estudos avaliados pelos pacientes, $2(9,0 \%)$ se propuseram a validar o instrumento; porém apenas um o fez com a metodologia adequada e o outro utilizou questionário semiestruturado. Quando os profissionais avaliam, $1(50,0 \%)$ realizou a avaliação por meio da análise de constructo e $1(50,0 \%)$ por meio de um instrumento baseado no SAM - Suitable assessment of materials, ou seja, avaliação da adequação de materiais.

Analisamos também se os artigos concluíam efetividade do uso do material escrito. Como resultado, obtivemos que 13 (59,0\%) dos artigos concluíram efetividade do uso do material escrito e ao restante dos artigos, ou seja, 9 (41,0\%) artigos não se aplicava essa questão, pois, os objetivos dos artigos foram variados, como descritos acima, o que poderia fornecer um falso dado se considerarmos que a efetividade do uso do material não foi realizada.

E como último dado do instrumento de coleta de dados, pesquisamos se os artigos que tinham como objetivos elaborar e avaliar materiais escritos utilizavam referências nacionais e internacionais quanto à elaboração e validação dos materiais escritos. Constatamos que dos $14(100,0 \%), 4$ (28,7\%) citavam referências nacionais; $4(28,7 \%)$ citavam referências internacionais; e $6(42,8 \%)$ citavam outros artigos que também tinham o objetivo de elaborar e/ou validar materiais escritos de orientação. 
6 DISCUSSÃO 


\section{DISCUSSÃO}

Ao longo dos anos, podemos observar que a Enfermagem vem ainda de forma incipiente produzindo elementos construtivos de produção tecnológica, mesmo que essa produção não venha sendo, majoritariamente, composta por artefatos e inventos, mas que incluem estratégias para controlar o processo de trabalho ou a estruturação de material didático-pedagógico para diferentes clientes ${ }^{(43)}$.

Encontramos nessa revisão 22 estudos sobre materiais escritos impressos, sendo que a fonte que recuperou o maior número de artigos foi a Lilacs, com 22 $(61,1 \%)$. Dos artigos selecionados, 7 (32,0\%) referem receber financiamento sendo que $4(57,0 \%)$ são do $\mathrm{CNPq}$. Os periódicos de publicação desses trabalhos foram diversos, sendo que todos são periódicos de grande inserção na profissão.

Percebemos, entretanto, pela prática clínica que o número de materiais escritos circulante é muito maior do que encontramos. Acerca disso, nos questionamos se os profissionais assistenciais, ou seja, aqueles que estão no cuidado direto com o paciente, não publicam trabalhos relacionados aos materiais escritos impressos de orientação em Enfermagem que produzem. Um trabalho de 1999 conclui que o posicionamento dos autores em relação à função do enfermeiro como educador é bastante destacado nas falas dos entrevistados, portanto, o enfermeiro brasileiro considera-se educador por excelência do cliente/paciente ${ }^{(16)}$.

Outra explicação possível para o fato de não termos encontrado mais artigos que retratassem os objetivos deste trabalho é a existência de uma grande variedade e pouco consenso entre os autores quanto à terminologia usada para os materiais escritos de orientação. Para a busca dos artigos foram utilizados 9 descritores e 7 palavras-chave. Quando pesquisamos o nome utilizado para designar o material escrito nos artigos selecionados em nossa pesquisa, encontramos 10 novos termos, sendo que todos eles são palavras-chave: manual de orientação, manual instrucional, cartilha de orientação, folheto de orientação, folheto educativo, instrumento educativo, manual ilustrado, material didático instrucional, material informativo e material instrucional.

A terminologia dada à atividade educativa em nível conceitual não concisa entre os pesquisadores também foi um dado encontrado em uma pesquisa sobre 
análise da educação de pacientes. As autoras também concordam que essas diferentes denominações podem levar a uma inadequada compreensão teórica e prática. Esse mesmo estudo esclarece que quanto aos recursos utilizados para a atividade educativa foram citados os seguintes: demonstrações, palestras, álbuns seriados, cartazes, manual de informação, diálogo e demonstração com devolução. Uma das grandes falhas dos trabalhos analisados foi a não explicitação da justificativa para a utilização desses recursos, em relação aos grupos de pacientes a que foram aplicados, assim como não há uma avaliação do emprego desses recursos ${ }^{(16)}$.

É importante ressaltar que cada nomenclatura (cartilha, manual, folheto, folder etc.) representa um tipo de material impresso, ou seja, os materiais apresentam diferenças entre si quanto ao formato e número de páginas. O Manual Normativo de Impressos do Departamento de Imprensa Oficial do Estado do Paraná, de 2012 ${ }^{(44)}$, esclarece que a filipeta é composta por apenas uma lâmina e sem dobra, porém o seu tamanho é cerca de $10 \mathrm{~cm}$ de largura por $20 \mathrm{~cm}$ de altura. Já o folder destina-se a materiais de diversos tamanhos que possuam uma lâmina apenas e com uma ou mais dobras. Os folhetos são materiais informativos que possuem até 12 páginas com formatos diversos, mas não tão grandes (de 10x15cm até $20 \times 28 \mathrm{~cm}$ ) e acabamento com grampos canoa. As cartilhas são muito parecidas com os folhetos, pois possuem conteúdos informativos, formatos semelhantes (com a diferença que cartilhas normalmente são menores), porém, a diferença está no número de páginas (que é superior) e no acabamento, que pode ser tanto com grampos canoa quanto com cola.

Com relação à caracterização dos autores, foi levada em consideração a titulação do autor na época. Quanto à titulação, encontramos um grande percentual de doutores, e em relação à profissão, destacam-se os docentes. Destacou-se o número de instituições de caráter federal, 7 (58,0\%), e a região mais citada dessas instituições foi a Sudeste com $6(50,0 \%)$, porém, se analisarmos as publicações por cidade, destacamos o número de publicações da cidade de Fortaleza com 6 (27,2\%) eventos. Encontramos dados parecidos em uma pesquisa sobre análise da educação e clientes/pacientes na literatura brasileira de Enfermagem, na qual dos 54 autores, 33 são profissionais da área da docência. Esse estudo concluiu que os docentes de enfermagem privilegiam a pesquisa em educação do paciente, além de que alguns autores publicaram mais de uma pesquisa ${ }^{(16)}$. 
Sabemos que esses dados são um reflexo do universo acadêmico, ou seja, esses autores são os professores que orientam os trabalhos científicos. Se fizermos uma relação entre o percentual de destaque dos enfermeiros e o tipo de publicação predominante, que foi pesquisa regular com 11 (50,0\%) das publicações, podemos refletir que esses profissionais estão trazendo para a pesquisa questões do seu interesse, ou seja, problemáticas da sua prática diária que necessitam ser investigadas, transformadas ou aprimoradas.

Ao analisarmos os delineamentos de pesquisa mais frequentes na amostra estudada, identificamos que $11(50,0 \%)$ são estudos qualitativos, $6(27,0 \%)$ são estudos quantitativos, e os estudos caracterizados como relato de experiência representam $5(22,7 \%)$ deles. A pesquisa qualitativa costuma ser descrita como mais holística, ou seja, é um estudo no qual há preocupação com os indivíduos e seu ambiente e toda sua complexidade. Baseia-se na premissa de que os conhecimentos sobre os indivíduos só são possíveis com a descrição da experiência humana tal como ela é vivida e tal como ela é definida por seus próprios autores ${ }^{(33)}$.

Os estudos podem ser classificados ainda quanto ao nível de evidências, a proposta por Melnyk e Fineout-Overholt (2011) possui sete níveis hierárquicos de evidências e engloba estudos com abordagens metodológicas quantitativas e qualitativas. São considerados como evidência de natureza forte, moderada ou fraca de acordo com o delineamento e o rigor metodológico empregados nos estudos analisados. Em nosso estudo optamos por não classificar os estudos quanto ao nível de evidência, pois a amostra desse estudo é composta por estudos ainda pré eliminares, realizados com populações pequenas e que não foram ainda replicados, sendo assim, todos eles seriam considerados de evidência fraca.

Entretanto, mais importante do que apontar o nível de evidência é resgatar o conhecimento que tem sido produzido sobre as características da comunicação dos materiais escritos impressos elaborados por enfermeiros brasileiros, que subsidiam as orientações em Enfermagem. Além disso, essa revisão nos atenta o quanto ainda é necessário estudar e escrever melhor sobre o fenômeno material escrito impresso.

Quando estudamos a especialidade para a qual o material escrito impresso foi destinado, a maioria é direcionada à oncologia e neonatologia, com 4 (18,0\%) cada uma, seguidos da endocrinologia, representado pelo grupo de pacientes diabéticos, neurologia e oftalmologia, com $2(9,0 \%)$ cada uma delas, seguidas de mais outras 8 
especialidades. Uma pesquisa sobre análise da educação de pacientes mostrou que a atividade educativa desenvolvida pelos enfermeiros mostra-se multidimensional no sentido de que abrange diferentes grupos de pacientes ${ }^{(16)}$.

Percebemos que grupos voltados para uma determinada especialidade têm se formado no intuito de elaborar materiais específicos. Desde 1990, o Grupo de Apoio e Reabilitação de Pessoas Ostomizadas - GARPO - Laringectomizados, da Escola de Enfermagem de Ribeirão Preto da Universidade de São Paulo, tem desenvolvido estudos direcionados para o ensino de laringectomizados ${ }^{(46)}$.

Já na área da infectologia, o Projeto Prisma do NESA/UERJ ${ }^{(47)}$ elaborou um estudo de avaliação qualitativa de materiais relativos à sexualidade e saúde reprodutiva. A partir de grupos focais com adolescentes, de oficinas interativas e uso de questionários com profissionais de saúde e educação (de instituições governamentais e não governamentais), os autores observaram a expressiva dificuldade dos referidos profissionais na avaliação dos recursos educativos (vídeos, cartilhas, folhetos, livros e jogos). Dentre os resultados do estudo destaca-se que: os materiais/meios são considerados facilitadores da abordagem do tema sexualidade e saúde reprodutiva; a avaliação de materiais ainda é vista como uma atividade individual (de "foro íntimo"), não sendo incorporada pela instituição como parte de um planejamento de ação; as iniciativas de avaliação são escassas e restritas à comparação de resultados obtidos e esperados e ao desempenho/nota ou ao número de atividades/consultas realizadas em determinado período. Ademais, foi também identificada a existência de um grande número de materiais sobre DST/Aids, cujo enfoque não contempla a integralidade dos temas sexualidade, gênero, saúde reprodutiva, família, e outros aspectos que interferem na vulnerabilidade individual e social dos adolescentes às DST/Aids ${ }^{(47)}$.

$\mathrm{O}$ "Guia de produção e uso de materiais educativos/Coordenação Nacional de DST e Aids"(48) enfatiza que é requerido que se tenha informação direcionada e dirigida a segmentos sociais selecionados. Cita que, no caso da Aids, nesses segmentos dirigidos estão os trabalhadores sexuais, homossexuais, bissexuais, internos dos sistema penitenciário, usuários de drogas, mulheres casadas, caminhoneiros e outros grupos. Cada um desses segmentos possui sua própria subcultura e seus próprios valores, o que precisará ser considerado na produção de mensagens a eles direcionadas. 
O mesmo guia supracitado também esclarece a relação entre a mensagem que se quer transmitir e o público-alvo. Deve-se observar a adequação da mensagem às metas e aos objetivos que se deve alcançar. Se o público-alvo for constituído por adolescentes com experiência sexual, por exemplo, mensagens que estimulem a abstinência tendem a cair no vazio. Seria melhor motivar a adoção de práticas sexuais seguras, privilegiando o uso consistente do preservativo.

Em nosso estudo quando pesquisamos sobre público-alvo - pacientes encontramos que a grande maioria é destinada aos adultos representando 11 (79,0\%) dos artigos, já quando pesquisamos sobre o público-alvo - acompanhantes encontramos que a maioria é destinada a acompanhantes de neonatos com 6 (43,0\%).

Além disso, encontramos um trabalho destinado para crianças e adolescentes $^{(49)}$ e outro destinado a crianças e adolescentes e seus familiares ${ }^{(50)}$. Um material de orientação não deve ser elaborado para públicos distintos, como, por exemplo, um único material destinado a crianças e adolescentes, pois esses públicos apresentam interesses e compreensões diferentes.

Percebemos que a maioria do material é destinada aos adultos, sendo assim, não houve grande variedade quanto à fase do ciclo vital dos sujeitos pesquisados, porém, encontrar essa variedade seria um resultado positivo, uma vez que a educação é um processo permanente que ocorre ao longo da vida. A educação em saúde consiste na adaptação e adequação aos diversos grupos etários da população ${ }^{(51)}$.

Já em relação ao local onde esse material será usado, destacam-se os hospitais e os ambulatórios com $9(41,0 \%)$ cada, setores que contemplam o nível terciário de atenção em saúde, o que nos leva a refletir que as práticas ainda estão voltadas para a cura de doenças e reabilitação e não focalizam a prevenção e promoção da saúde. Esse resultado também é encontrado em outro estudo que define o conteúdo dos programas educativos como informações processuais que descrevem a natureza dos procedimentos terapêuticos, quando, onde e por quem será realizado e os riscos, descrevem ainda as sensações que o paciente pode esperar. O conteúdo abrangido é essencialmente da área temática da doença e não da visão de saúde ${ }^{(16)}$.

Quanto aos objetivos dos artigos, verificamos que, dos 22 (100,0\%) artigos, 7 $(32,0 \%)$ têm como objetivo relatar o processo de elaboração do material impresso. A necessidade de manter os pacientes informados é amplamente reconhecida e praticada nos atendimentos clínicos. Tal fato motiva a produção de materiais 
impressos para diversos propósitos, tais como: orientar e adaptar comportamentos, promover a saúde, prevenir futuros acometimentos ou informar sobre riscos e estilos saudáveis de vida. Assim, de uma forma geral, os materiais impressos usados na educação em saúde têm como objetivo divulgar conteúdos considerados importantes para a prevenção ou tratamento de enfermidades. De maneira mais específica, esses materiais informam sobre mecanismos que determinam ou favorecem estados ideais de saúde, procuram reforçar orientações transmitidas oralmente em consultas e contribuir na implementação pelo próprio indivíduo de cuidados necessários ao tratamento ou prevenção de doenças. Esses materiais de divulgação, nos formatos de cartazes, cartilhas, folders, panfletos, livretos, são convencionalmente chamados de "materiais educativos" nos serviços de saúde, por fazerem parte da mediação entre profissionais e população ${ }^{(47)}$.

Refletindo-se sobre todos esses conceitos, faz-se extremamente importante lembrar que os materiais de orientação impressos devem ser utilizados como instrumentos que subsidiam as orientações verbais e não simplesmente as substituem. O uso de materiais educativos é algo que deve ser complementado por outras práticas educativas, pois eles não podem ser considerados como fins em si mesmos. Deve-se, sempre, complementar a distribuição do material com orientações sobre seu conteúdo. A educação em saúde representa um processo, portanto, a utilização de somente um material educativo não garante bons resultados. Qualquer material educativo utilizado apresentado isoladamente resultará em pouca eficácia na ação educativa que se objetiva ${ }^{(52)}$.

Pesquisamos se os artigos que tinham como objetivos elaborar e avaliar materiais escritos utilizavam referências nacionais e internacionais quanto à elaboração e validação dos materiais escritos. Constatamos que dos 14 (100,0\%), 4 (28,7\%) citavam referências nacionais; 4 (28,7\%) citavam referências internacionais; e $6(42,8 \%)$ citavam outros artigos que também tinham o objetivo de elaborar e/ou validar materiais escritos de orientação. Entre as autoras nacionais mais citadas encontramos Maria de Fátima Moreira, Maria Miriam Lima da Nóbrega e Maria Iracema Tabosa da Silva (2003), Isabel Cristina Echer (2005) e entre os internacionais os mais citados foram Cecilia Conrath Doak, Leonard G. Doak e Jane H. Root (1996). 
É importante destacar que, pela escassez de trabalhos no Brasil sobre como elaborar materiais escritos impressos, esses artigos que relatam a elaboração são utilizados como guia/modelo para outros profissionais enfermeiros, muitas vezes de especialidades distintas, interessados em elaborar esse tipo de material. Podemos verificar esse dado quando lemos as referências bibliográficas utilizadas nos artigos.

A preocupação com a elaboração do material escrito também é abordada por vários autores, eles reconhecem a adequação de vários itens durante a elaboração tais como adequação da linguagem, conteúdo, layout, design, figuras/ilustrações. Considerando-se essa importância, foi elaborado um quadro que reúne informações relevantes relacionadas à linguagem, ilustração e layout.

Quadro 3 - Aspectos de Linguagem, Ilustração e Layout que devem ser considerados na elaboração do material educativo em saúde.

\section{LINGUAGEM}

a) A credibilidade da mensagem - Comunicar uma mensagem de credibilidade que esteja relacionada com o autor e a fonte da mensagem, devendo ambos ser confiáveis e apropriados ao contexto sócio-econômico e cultural.

b) A apresentação da mensagem

* Apresentar ao leitor de 3 a 4 idéias principais por documento ou por secção.

Desenvolver uma ideia por vez, de forma completa, para, depois, passar para uma seguinte, já que idas e vindas entre tópicos podem confundir o leitor.

Evitar linhas longas, uma vez que os leitores, principalmente aqueles com pouca habilidade, geralmente esquecem itens de listas muito longas, sendo, por isso necessário a limitação a quatro ou cinco itens.

Declarar objetivamente a ação que se espera do leitor.

* Apresentar os conceitos e ações numa ordem lógica.

* Clarificar ideias a conceitos abstratos com exemplos.

Incluir apenas as informações necessárias, para que o leitor compreenda e siga a mensagem.

Destacar a ação positiva dizendo ao leitor o que ele deve fazer e não o que ele não deve fazer.

* Dizer aos leitores os benefícios que eles terão com a leitura do material. 


\section{continuação}

Quadro 3 - Aspectos de Linguagem, Ilustração e Layout que devem ser considerados na elaboração do material educativo em saúde.

c) A estrutura da frase e seleção das palavras

* Usar, sempre que possível, palavras curtas

* Construir sentenças com 8 a 10 palavras e parágrafos com 3 a 5 sentenças.

* Escrever como se estivesse conversando, pois o estilo conversacional é mais natural e mais fácil de ser lido e entendido.

* Usar a voz ativa.

* Limitar o uso de jargão, termos técnicos e científicos. Se forem indispensáveis, explique-os em linguagem que o leitor possa entender.

* Usar palavras com definições simples e familiares.

- Usar analogias familiares ao público-alvo.

* Evitar abreviaturas, acrônimos e siglas.

d) Não discriminação das diferenças culturais e racionais

* Identificar um grupo de pessoas pela raça ou etnia, através do termo adotado pelo mesmo.

* Elaborar mensagens adequadas a cada grupo ou subgrupo cultural ou étnico.

e) Incluindo interação

- Fazer perguntas curtas e deixar espaço para o leitor escrever as respostas.

* Pedir ao leitor para fazer escolhas, circulando ou marcando a opção correta, entre várias apresentadas (com texto ou imagem).

* Deixar espaço em branco no fím do material destinado a anotações de dúvidas, questionamentos a pontos importantes. 


\section{continuação}

Quadro 3 - Aspectos de Linguagem, Ilustração e Layout que devem ser considerados na elaboração do material educativo em saúde.

\section{ILUSTRAÇÕES}

a) Seleção da ilustração

* Limitar o número de ilustrações para não sobrecarregar o material.

* Selecionar ilustrações que ajudam a explicar ou enfatizar pontos e idéias importantes do texto.

* Evitar ilustrações abstratas e que tenham apenas função decorativa no texto.

* Evitar desenhos e figuras estilizadas.

* Ilustrar a ação ou o comportamento esperado ao invés do que deve ser evitado.

Atentar para o fato de que as fotografias funcionam melhor para representar eventos da vida real, mostrar pessoas e comunicar emoções.

* Utilizar desenhos de linhas simples, que funcionam melhor para ilustrar um procedimento.

* Não usar caricatura para ilustrar partes ou itens relacionados com a saúde.

* Usar ilustrações apropriadas ao leitor, evitando ilustrar material dirigindo ao público adulto/idoso com motivos infanto-juvenis e vice-versa.

Quando usar ilustrações de órgãos internos do corpo ou de pequenos objetos, utilizar imagens realistas e colocá-las no contexto real.

* Apresentar os pequenos objetivos em ilustrações maiores para que os detalhes sejam visualizados, mas apresentar uma escala para compará-los com alguma coisa familiar à clientela.

* Usar fotos e ilustrações de boa qualidade e alta definição.

* Usar, com cautela, caricaturas. Elas são boas para comunicar humor, mas podem não ser entendidas por alguns leitores. 


\section{continuação}

Quadro 3 - Aspectos de Linguagem, Ilustração e Layout que devem ser considerados na elaboração do material educativo em saúde.

b) Ilustrações sensíveis e relevantes culturalmente

* Usar imagens e símbolos familiares ao público-alvo, que permitam às pessoas se identificarem com a mensagem.

- Usar, com cautela, símbolos e sinais pictográficos. Símbolos "universais" como sinal de pare, $\mathrm{X}$ e setas, por exemplo, podem não ser entendidos pelo público alvo.

* Considerar, nas ilustrações apresentadas, as características racionais e étnicas do público-alvo.

* Mostrar pessoas dos mais variados grupos, idades e etnias, se o material for para um público diverso.

c) Disposição das ilustrações

* Dispor as ilustrações de modo fácil, para o leitor segui-las e entendê-las.

* Apresentar uma mensagem por ilustração.

* Ilustrar apenas os pontos mais importantes a fim de evitar material muito denso.

* Colocar as ilustrações próximas aos textos aos quais elas se referem.

* Usar legendas que incluam a mensagem chave.

* Numerar as imagens, quando forem apresentadas em sequência.

* Usar setas ou círculos para destacar informações-chave na ilustração.

continua 


\section{continuação}

Quadro 3 - Aspectos de Linguagem, Ilustração e Layout que devem ser considerados na elaboração do material educativo em saúde.

\section{LAYOUT E DESIGN}

a) Fontes, cores e sombreamentos

* Usar fonte 12, no mínimo. Se o material destina-se ao público adulto, usar, no mínimo, 14.

Usar fontes para os títulos, dois pontos maiores que as do texto.

* Evitar textos apenas com fontes estilizadas e maiúsculas, pois dificultam a leitura.

- Usar itálico, negrito e sublinhado apenas para os títulos ou para destaques.

* Usar as cores com sensibilidade e cautela, para não supercolorir, deixando o material visualmente poluído.

* Impressão preta sobre fundo claro é mais fácil de ler.

* Impressão fosca (papel e tinta) melhora a legibilidade pela redução do brilho.

b) Capa de efeito atrativo

* Fazer uma capa com imagens, cores e texto atrativos.

* Mostrar a mensagem principal e o público-alvo na capa, permitindo que o leitor capte a mensagem principal apenas por sua visualização.

c) Organização da mensagem para facilitar a ação desejada e a lembrança

* Sinalizar adequadamente os tópicos e subtópicos, usando recursos, como títulos, subtítulos, negritos e marcadores.

Colocar, no início da frase ou da proposição, as palavras ou ideias-chave.

* Apresentar uma ideia completa numa página ou nos dois lados da folha, pois, se o leitor tiver que virar a página, no meio da mensagem, ele poderá esquecer sua primeira parte.

- Colocar a informação mais importante no início e no fim do documento.

* Organizar as ideias no texto na mesma sequência em que o público-alvo irá usá-las.

Colocar a informação-chave numa caixa de texto, para facilitar a localização da informação na página. 


\section{continuação}

Quadro 3 - Aspectos de Linguagem, Ilustração e Layout que devem ser considerados na elaboração do material educativo em saúde.

d) Espaço em branco, margens e marcadores

* Deixar, no mínimo, 2,5 cm de espaço em branco nas margens da página e entre as colunas.

* Limitar a quantidade de texto e imagens na página.

* Usar títulos e subtítulos, deixando mais espaço acima que abaixo deles, para dar uma ligação mais forte.

Fonte: Moreira MF, Nóbrega MML, Silva MIT. Comunicação escrita: contribuição para a elaboração de material educativo em saúde. Rev Bras Enferm. 2003;56(2):184-8.

O quadro 3 nos orienta sobre os itens a serem levados em consideração ao se elaborar um material educativo impresso, entretanto, esse não deve ser tomado como um referencial rígido, mas sim como uma proposta de trabalho que deve ser flexibilizada de acordo com o público com o qual irá se trabalhar. O item relacionado à linguagem, no item "d", descreve que não se deve discriminar as diferenças culturais e racionais. Tomemos como exemplo o item layout e design. Quando o público-alvo forem idosos, ou pessoas com dificuldades visuais, podemos por exemplo, utilizar uma fonte de tamanho maior, impressão preta sobre o fundo claroimpressão fosca (papel e tinta) melhora a legibilidade pela redução do brilhos -, ou seja, instrumentos que facilitem a visualização da mensagem.

Em relação à linguagem, muitas vezes, não notamos que estamos utilizando uma linguagem técnica que só os profissionais da área compreendem e os manuais são construídos, por exemplo, para fortalecer a orientação aos familiares e pacientes, sendo, portanto, indispensável escrever os textos numa linguagem que todos entendam $^{(5)}$. Os autores do quadro 3 concordam com essa orientação quando descreve que em relação à linguagem devemos atentar para a credibilidade da mensagem, adequando os autores e a fonte da mensagem ao contexto sócioeconômico e cultural do público-alvo. 
Em nosso trabalho encontramos que a linguagem foi o quarto aspecto mais citado quando pesquisamos sobre os itens que devem ser considerados ao elaborar o material de orientação impresso. Esse dado demonstra que entre os artigos estudados, há a percepção da adequação na maneira que irá se transmitir a mensagem, porém os dados também demonstram que esse aspecto ainda precisa ser estudado mais profundamente. É um item de extrema importância, pois está diretamente relacionado à compreensão ou não da mensagem pelo leitor.

No processo de validação de conteúdo do manual educativo para mulheres mastectomizadas, as respostas dos juízes foram que a maioria dos problemas identificados são alterações de determinados termos ou expressões, por meio da substituição, exclusão ou acréscimo de palavras que facilitariam a compreensão da população-alvo. A sugestão "substituição de termos" foi encontrada em quase todos os tópicos. Os termos técnicos e os eufemismos desnecessários devem ser evitados. A linguagem deve ser clara, simples e direta, devendo ser evitada a ordem inversa das orações ${ }^{(34)}$.

A estrutura do texto também é um fator importante a ser considerado. Os textos apresentados na forma de perguntas e respostas, ao discutir problemas e suas soluções, fazer escolhas e demonstrar, aumenta a retenção do conteúdo pelo leitor ${ }^{(5)}$. Em outra pesquisa, evidenciou-se que, embora os assuntos sejam apresentados dessa forma, pressupondo um paciente virtual com dúvidas, as respostas são mediadas por linguagens ambíguas (popular e científica). A linguagem popular busca dar visibilidade ao sujeito no diálogo, com uma linguagem informal e despojada. Assim, a valorização da linguagem popular permite que o educando se faça presente no texto e mantenha a sua iniciativa no processo da educação e saúde. A adoção da linguagem científica na apresentação dos conteúdos do folheto impresso destaca-se por suas determinações essencialmente técnicas, por vezes difíceis de serem compreendidas, com limitações impostas pela faixa etária, condições de escolaridade e classe social do paciente e familiar ${ }^{(6)}$.

A linguagem com sentido ambíguo é o vício de linguagem que consiste em usar diversas palavras na frase de maneira a causar duplo sentido na sua interpretação, dificultando a compreensão do leitor. O conteúdo do material pode ser programado de forma que os termos referentes à linguagem se tornem claros e de fácil leitura para o leitor ${ }^{(6)}$. 
Ainda com relação à linguagem, a extensão das frases também deve ser considerada. Frases longas reduzem a velocidade no processo de leitura e geralmente geram compreensão mais dificultosa. Palavras comuns devem ser usadas quase o tempo todo já palavras técnicas e conceitos devem ser explicados por meio de exemplos ${ }^{(28)}$. Os autores do quadro também fazem referência à estrutura da frase $\mathrm{e}$ seleção das palavras, descrevendo que sempre que possível devemos utilizar palavras curtas com definições simples e claras e construir sentenças com 8 a 10 palavras e parágrafos com 3 a 5 sentenças, pois os leitores, principalmente aqueles com pouca habilidade, geralmente esquecem itens de listas muito longas.

Encontramos também a legibilidade enquanto aspecto a ser considerado quando estudamos a linguagem, lembrando que o índice de legibilidade (IL) referese ao grau de escolaridade exigido de um leitor para que possa entender uma determinada passagem escrita ${ }^{(28)}$. O Índice de Legibilidade (IL) de um texto é um fator importante para a compreensão do paciente. Levar em conta a adequação do referido índice na elaboração e seleção do material impresso certamente determinará resultados mais positivos para o paciente, traduzidos em melhor controle da saúde, menor incidência de complicações e melhoria da qualidade de vida ${ }^{(53)}$.

Consultando a literatura internacional, verificamos que este índice é usado no exterior como indicativo de qual material escrito será entregue ao paciente. Para tanto, inicialmente é realizado um teste com o paciente avaliando qual é seu índice de legibilidade, a partir daí, é entregue um material escrito preparado especificamente para o seu nível de compreensão ${ }^{(28)}$.

Outro aspecto a ser considerado na elaboração são as figuras/ilustrações. Autores concordam que a imagem representa um fator decisivo na atitude de ler ou não a instrução, deve ser amigável, chamar a atenção do público-alvo e retratar claramente o propósito do material $^{(28)}$. É importante procurar ilustrar as orientações para descontrair, animar o material, torná-lo menos pesado e facilitar o entendimento, já que, para algumas pessoas, as ilustrações explicam mais que muitas palavras $^{(5)}$. Desenhos de linhas simples podem promover realismo, sem incluírem detalhes indesejados. As fotografias incluem frequentemente, detalhes não desejados e dispensáveis, como fundo de quarto, bordas elaboradas, cor desnecessária, que podem distrair o leitor ${ }^{(28)}$. Já os autores do quadro 3 referem que as fotografias 
funcionam melhor para representar eventos da vida real, mostrar pessoas e comunicar emoções.

Para que as ilustrações auxiliem no processo de compreensão da mensagem, os autores do quadro 3 destacam que elas devem ser selecionadas de modo que não sobrecarreguem o material, mas ajudem a explicar ou enfatizar pontos e ideias importantes no texto. Destacam ainda o uso de ilustrações apropriadas ao leitor, evitando ilustrar material dirigido ao público adulto/idoso com motivos infantojuvenis e vice-versa. Em nosso trabalho encontramos que as figuras e ilustrações foram o segundo aspecto mais citado quando pesquisamos sobre os itens que devem ser considerados ao elaborar o material de orientação impresso. Compreendemos a importância desse item, entre outros, no sentido de colaborar para compreensão da mensagem, para isso, conforme o quadro 3, as figuras devem ser criteriosamente selecionadas, devem ser relevantes culturalmente e dispostas no texto de maneira clara. Considerar a importância desse item é também considerar relevante o trabalho em equipe, incluindo a participação de profíssionais específicos da área.

Muitas pesquisas têm se utilizado da figura como uma ferramenta. Em um trabalho de elaboração de cartilhas para orientação do autocuidado no programa educativo em diabetes, os autores decidiram pela confecção de uma cartilha educativa ilustrada com figuras, para tirar dúvidas, que pudesse ser levada para o domicílio, e que seria mais acessível para o autocuidado dos pacientes, facilitando a comunicação visual e o acesso por parte dos sujeitos com pouca familiaridade com a linguagem escrita ${ }^{(54)}$.

Consideramos também o layout como outro aspecto a ser observado ao se elaborar um material escrito. Em nosso trabalho encontramos que o layout foi o último aspecto citado quando pesquisamos sobre os itens que devem ser considerados ao elaborar o material de orientação impresso. Esse dado demonstra o quanto ainda é necessário pesquisar e divulgar a importância desse item, pois ao visual do material pode ser um atrativo ou não para a leitura ou não do material.

Em um trabalho cujo objetivo era a elaboração de um folheto educativo, o conteúdo do material educativo foi escrito utilizando-se estilo de letras simples e fáceis de serem lidas, com os itens destacados em negrito. Essas fontes tiveram cores diferentes de acordo com o destaque que se pretendia dar ao texto ${ }^{(6)}$. Quando muitos tipos de fontes e tamanhos diferentes (seis ou mais) são usados em uma página 
podem confundir o leitor e deixar o foco incerto, sendo sugerido, para pontos fundamentais, negrito e tipo de fonte, tamanho e cores diferentes ${ }^{(6)}$. Os autores do quadro 3 complementam essa informação referindo que deve-se evitar textos apenas como fontes estilizadas e maiúsculas, pois dificultam a leitura, usar itálico, negrito e sublinhado apenas para os títulos ou para destaques. Referem ainda que as cores devem ser usadas com sensibilidade e cautela, para não supercolorir, deixando o material visualmente poluído.

Incluímos ainda em nosso trabalho informações relevantes em relação à elaboração do material escrito relacionadas ao conteúdo. Deve-se buscar na literatura especializada o conhecimento científico existente sobre o assunto definindo conceitos e cuidados importantes que, se seguidos, podem contribuir para o manejo e recuperação de pacientes submetidos a diferentes tratamentos. Isso proporciona segurança ao usuário e reconhecimento do valor da equipe de profissionais ${ }^{(5)}$.

O material intitulado "Cuidados com o bebê prematuro: cartilha educativa para orientação materna" contém 48 páginas e apresenta-se dividido em justificativa, objetivo, breve conceituação sobre o bebê prematuro, 29 perguntas e respostas sobre relacionamento familiar (3), alimentação (9), higiene (3), cuidados diários (9) e especiais (5), lista de telefones úteis, anotações e referências bibliográficas ${ }^{(11)}$.

Ainda em relação ao conteúdo do material, um estudo apontou a inexistência de pesquisas prévias para a seleção de conteúdo dos impressos. Os autores acreditam que ao não se realizarem pesquisas, resulta simplificações, generalizações e reducionismos, porque os conteúdos passam a se referir ao que os profissionais acreditam que "o paciente quer". De acordo com esses autores, os únicos estudos prévios à produção, apontados na literatura, restringem-se ao conhecimento do nível de escolaridade do público, como se esta informação fosse suficiente para traçar um perfil consistente dele ${ }^{(9)}$.

Verificamos também se para a elaboração do material escrito o autor contava com a colaboração do público para qual o material se destinava e se outros profissionais da equipe multidisciplinar colaboravam. Em relação ao público-alvo, encontramos que $3(38,0 \%)$ colaboram por meio de entrevistas, sendo que 2 delas são semiestruturadas, $3(38,0 \%)$ colaboram por meio dos grupos, sendo que um deles utilizou a filmagem como recurso e outro o grupo focal. Encontramos ainda 1 
$(13,0 \%)$ colaborando por meio do círculo de discussão e $1(13,0 \%)$ por meio de questionário.

Em relação ao conteúdo do material impresso é consenso entre os autores a necessidade de incluir o público-alvo nesse processo para que os materiais não sejam mais elaborados de acordo com as dúvidas que os profissionais pensam ser dos pacientes.

Retomando os referenciais teóricos desse trabalho, que são abordagens pedagógicas, comunicação interpessoal e enfermagem e elaboração de material educativo escrito impresso, podemos perceber que os conceitos desses referenciais apresentam um ponto em comum: a preocupação com a percepção das necessidades do destinatário da mensagem que será recebida.

Em relação à comunicação, destacamos que entre os aspectos envolvidos na comunicação interpessoal estão as tentativas de compreender o outro comunicador e de se fazer compreendido. Nesse processo, incluem-se ainda a percepção da pessoa, a possibilidade de conflitos, que podem ser intensificados ou reduzidos pela comunicação e de persuasão-indução a mudanças de valores e comportamentos ${ }^{(19)}$. Sendo assim, a tarefa do profissional da saúde é decodificar, decifrar e perceber o significado da mensagem que o paciente envia, para só então estabelecer um plano de cuidados adequado e coerente com as suas necessidades. Assim a comunicação terá mais chances de ser adequada, ou seja, tentará diminuir conflitos, malentendidos e atingir objetivos definidos para a solução de problemas detectados na interação com os pacientes ${ }^{(19)}$.

Já em relação às abordagens pedagógicas, a Pedagogia da Problematização enfatiza que o respeito à autonomia e à dignidade de cada um é imperativo ético e não um favor que podemos ou não conceder uns aos outros. Saber que devemos respeito à autonomia, à dignidade e à identidade do educando e, na prática, procurar coerência com este saber, nos leva inapelavelmente à criação de algumas virtudes ou qualidades sem as quais aquele saber vira inautêntico, com palavreado vazio e inoperante $^{(8)}$.

Seguindo esse mesmo conceito, artigos mais recentes que retratam sobre a elaboração de materiais educativos enfatizam a participação do público- alvo no processo de elaboração e avaliação do material como sujeitos ativos capazes de expressar seus desejos e percepções. 
Já em relação a qual profissional colabora na elaboração do material escrito, encontramos um total de 8 eventos $(100,0 \%)$ dos quais o que apresenta maior frequência é a equipe multidisciplinar, com 3 (38,0\%), os outros profissionais se dividem em $1(13,0 \%)$ técnico em tratamento de imagem, 1 (13,0\%) técnico em audiovisual, 1 (13,0\%) psicólogo, 1 (13,0\%) artista plástico e 1 (13,0\%) médico. A elaboração do conteúdo deve contar com o auxílio de equipe multiprofissional que contemple não apenas profissionais da saúde, mas também profissionais de diversas áreas. Analisando-se as características de cada item do quadro 3, do que deve ser considerado durante a elaboração do material escrito, podemos perceber que o próprio quadro justifica a necessidade de trabalhar com uma equipe multiprofissional, visto a diversidade de áreas de conhecimento. Sendo assim, o trabalho em equipe propicia que cada profissional contribua de acordo com a sua especialidade, pois todos almejam o mesmo objetivo.

Tomemos como exemplo o conceito do marketing. O objetivo principal do marketing é entender, criar e comunica-se de forma efetiva. Contudo, para realizá-lo de forma eficaz é necessário o planejamento, a implementação e o controle de programas desenvolvidos para criar, construir e manter trocas benéficas com compradores-alvo para que sejam alcançados os objetivos, o marketing exige, portanto, comunicação com o público-alvo ${ }^{(55)}$.

O marketing é um processo social por meio do qual pessoas e grupos de pessoas obtêm aquilo de que necessitam e desejam por meio da criação, oferta e troca de produtos e serviços. Marketing é uma via de duas mãos entre o mercado e as organizações, em que estas buscam no mercado informações sobre seus desejos e necessidades, recebendo como retorno, nesta primeira fase, as informações. $O$ marketing tornou-se uma força difundida e influente em todos os setores da economia. Como passo seguinte, as organizações passam a oferecer ao mercado os produtos e serviços de acordo com os desejos e necessidades dos clientes, tendo como retorno recursos financeiros e clientes satisfeitos ${ }^{(55)}$.

Em nosso estudo, apesar de encontrarmos a participação tanto do público quanto dos profissionais, avaliamos pelos dados encontrados que essa participação ainda é muito discreta e que precisa ser incentivada. O que ainda é considerado mais relevante na elaboração é o conteúdo do material. 
Esse resultado também é encontrado na literatura, quando percebemos que ao longo dos anos houve uma mudança na postura dos enfermeiros como educadores, no sentido de em suas atividades educativas incorporarem os usuários dos serviços de saúde, pois esses possuem a capacidade de contribuir para tomada de decisões em saúde. Em nosso estudo, observamos que os trabalhos da década de 80 e do início da década de 90 tinham como objetivo elaborar o conteúdo do material de acordo com a rotina do setor em questão ou relatar o uso de um material elaborado pelos próprios profissionais, que pretendiam esclarecer dúvidas que pensavam ser dos pacientes. Nesse sentindo, comparamos resultados de dois trabalhos publicados em épocas distintas.

Um trabalho que buscou identificar os aspectos conceituais e operacionais da atividade educativa do enfermeiro com o paciente/cliente, na literatura de enfermagem, no período de 1980 a 1995, concluiu que a educação de paciente é uma ação instrumental e de proteção do enfermeiro para com o paciente, em que o fornecimento de informação (orientação) é sua essência. Pelos conteúdos desenvolvidos nos programas educativos o enfermeiro abrange apenas temas relacionados à doença e ao tratamento. Esses conteúdos são fragmentados e não há abordagem quanto aos aspectos sociais e ambientais da doença. Além disso, percebeu-se que havia maior número de experiências com o ser doente (paciente) em relação ao ser saudável, isto é, a enfermagem brasileira era mais atuante no ensino de pacientes que na educação de clientes ${ }^{(16)}$.

Entretanto, outro estudo mais recente, que objetivou analisar a realidade das práticas educativas em saúde implementadas por enfermeiros no período de 1998 a 2008, identificou como público-alvo pessoas sadias e aquelas em condições crônicas. Além disso, a participação efetiva de clientes, famílias e comunidade nas ações de educação em saúde tem se mostrado como um fator de êxito dessas atividades, que culminam na autonomia dos sujeitos em questão nas práticas do autocuidado e, principalmente, na promoção da saúde, na qual estão incluídos inúmeros outros aspectos. Percebe-se uma mudança na realização de tais ações, que vêm sendo mais efetivadas de forma conjunta e construtiva com a população, superando o modo tradicional de educação e possibilitando as ações efetivas de promoção e educação em saúde ${ }^{(51)}$. 
Essa mudança de visão relacionada à educação em saúde também pode ser observada em estudos relacionados aos materiais escritos de orientação impressos em Enfermagem. Iniciativas de produção de materiais educativos que incorporem o paciente como sujeito do conhecimento em situação real, e não virtual, facilitam a mediação de conteúdos, pois a linguagem fica mais próxima do entendimento do leitor e mais aderente à sua realidade. Entende-se como paciente virtual o leitor que é inscrito no texto como um paciente imaginário com dúvidas ${ }^{(6)}$.

Entretanto, outro estudo recente, que teve como objetivo apresentar os resultados de uma pesquisa bibliográfica sobre o uso de materiais impressos na educação em saúde, enfocando os modelos de comunicação, as representações dos usuários e as dinâmicas da seleção de conteúdos e de avaliação, constatou que os artigos apontam que a comunicação se caracteriza predominantemente pelo modelo linear. $O$ modelo unilinear se caracteriza por tomar a comunicação como, essencialmente, uma relação entre um emissor e um receptor, na qual o emissor aplica determinados estímulos e obtêm, do receptor, determinadas respostas. Tratase, fundamentalmente, de um modelo marcado pela unilinearidade, porque supõe o primado de uma direção única de comunicação (do polo emissor ao receptor), e pela causalidade de um polo sobre o outro, ou seja, as ações do emissor causam reações razoavelmente previsíveis no receptor ${ }^{(56)}$. Em relação a esses resultados temos que considerar as diferenças dos critérios de inclusão e exclusão dos artigos, as bases de dados pesquisadas, bem como a utilização de quais descritores e palavras-chave selecionados para cada pesquisa.

A colaboração de outros profissionais também tem sido utilizada nas pesquisas. Um trabalho selecionado em nosso estudo buscou envolver os docentes da disciplina Interdisciplinaridade na Educação em Diabetes e estudantes para elaboração de cartilhas, em uma perspectiva de articulação entre ensino e pesquisa. A equipe multidisciplinar do programa educativo em diabetes propôs aos alunos do curso de graduação em Enfermagem e Nutrição a participação no processo de elaboração do material informativo/educativo para a orientação do autocuidado. $\mathrm{O}$ corpo docente da disciplina foi composto por um enfermeiro docente e cinco outros profissionais de saúde (médico, enfermeiro, fisioterapeuta, nutricionista e terapeuta ocupacional) $^{(54)}$. 
A avaliação por profissionais de diferentes áreas (saúde, educação, relações públicas e letras) é uma ocasião em que se pode afirmar que o trabalho está sendo feito em equipe, valorizando as opiniões e enfoques diversos sobre o mesmo tema. Muitas vezes, numa mesma equipe, diferentes profissionais envolvidos no tratamento de um paciente apresentam condutas diversas em relação a cuidados com a sua saúde. A construção do manual é também uma oportunidade para uniformizar e oficializar as condutas no cuidado ao paciente, com a participação de todos ${ }^{(5)}$.

Considerando então fundamental a participação dos profissionais e do público-alvo, gostaríamos de enfatizar de que maneira os dados dessa participação serão coletados. Todo processo científico prescinde de uma boa coleta de dados. As estratégias mais utilizadas nas pesquisas de enfermagem são: entrevistas, questionários, técnicas de observação e revisão de registros ${ }^{(33)}$.

A utilização das entrevistas requer planejamento prévio e manutenção do componente ético, desde a escolha do participante, do entrevistador, do local, do modo ou mesmo do momento para sua realização. Pesquisas com uso de entrevista envolvem necessariamente seres humanos. Desta forma, o projeto precisa ser encaminhado previamente para análise e parecer de um Comitê de Ética em Pesquisa $^{(57)}$.

Para a elaboração e adequação do roteiro de entrevista consideram-se a vivência do pesquisador, a literatura sobre o tema em estudo, a apreciação de juízes e as informações obtidas no pré-teste. Os juízes são geralmente pessoas envolvidas em pesquisas, capacitados na avaliação e ajuste do roteiro. Seu papel fundamental é indicar se os termos utilizados são compreensíveis e adequados à população a que se destina a existência de questões que geram dificuldade de interpretação, se o instrumento favorece o envolvimento do entrevistado na resposta das questões e se atinge o objetivo proposto ${ }^{(57)}$.

É indicado o uso de gravador na realização de entrevistas para que seja ampliado o poder de registro e captação de elementos de comunicação de extrema importância, pausas de reflexão, dúvidas ou entonação da voz, aprimorando a compreensão da narrativa ${ }^{(58)}$.

Um bom entrevistador é aquele que sabe ouvir, mas o faz de forma ativa, demonstrando ao entrevistado o interesse em sua fala, em suas emoções, realizando novos questionamentos, confirmando com gestos e expressões faciais o que ouve 
atentamente e sua compreensão, mas sem influenciar no discurso. Ele aprofunda o relato do participante e mostra atenção a detalhes importantes ${ }^{(57)}$.

Terminada a entrevista o pesquisador deve agradecer o recebimento das informações e se colocar à disposição para esclarecimento de dúvidas ou recebimento de sugestões. Posteriormente, realizar a transcrição, de preferência em ambiente silencioso e distante da circulação de outras pessoas ${ }^{(57)}$.

Outra forma de se coletar dados é o círculo de discussão. Esse artifício é considerado uma técnica de abordagem qualitativa valorizada por conseguir trazer à tona as opiniões, relevâncias e valores dos sujeitos da pesquisa em relação a um determinado tema ${ }^{(11)}$.

Em outra pesquisa as atividades nos pequenos círculos de discussão foram organizadas tendo como foco os seguintes questionamentos: 1. Qual a relevância do material educativo nas atividades de educação em saúde para a alta hospitalar? 2. Quais temas e seus conteúdos deveriam ser trabalhados no material educativo? 3. Que tipo de material de ensino deveria ser utilizado? As discussões foram gravadas na íntegra e, posteriormente, transcritas para a análise. Além disso, utilizamos o Diário de Campo para registros de manifestações não verbais. As informações recolhidas foram devidamente organizadas e sistematizadas ${ }^{(11)}$.

Já o grupo focal prevê a obtenção de dados a partir de discussões cuidadosamente planejadas onde os participantes expressam suas percepções, crenças, valores, atitudes e representações sociais sobre uma questão específica num ambiente permissivo e não constrangedor. Os grupos focais são flexíveis. Em vez de seguir um roteiro rígido de questões, como ocorre com os estudos de amostragem, o moderador de uma discussão em grupo tem maior flexibilidade do que o entrevistador individual e tem liberdade para modificar a ordem das questões ou sua redação com vistas ao aprofundamento das respostas. Assim, as sessões de grupo permitiram aos participantes escaparem de respostas do tipo "sim ou não", "concordo ou discordo", trazendo elementos para a elucidação do problema que de outra forma não teriam sido considerados. Os grupos focais possibilitam ainda a emergência de conflitos e pontos de estrangulamento que abriram espaço para atividades educativas consequentes $^{(58)}$.

É diferente da entrevista em grupo porque para o grupo focal a interação é imprescindível e o pesquisador precisa encorajar os participantes para que falem uns 
com os outros ${ }^{(59)}$. As possibilidades que os grupos focais oferecem a quem trabalha com educação em saúde não são exclusivas desta técnica. Porém, os grupos focais possibilitam a obtenção de dados mais rapidamente e com custos mais baixos ${ }^{(57)}$.

Ressaltamos que o pesquisador, a partir do desenvolvimento e utilização de uma estratégia de coleta de dados, deve evidenciar sua validade e confiabilidade para aquela situação. Tal procedimento facilita o trabalho de outros pesquisadores, que podem utilizar essa estratégia válida e confiável ${ }^{(60)}$.

O conceito de validade se aplica não só aos instrumentos de coletas de dados, mas também aos materiais escritos impressos de orientação em Enfermagem. Um estudo nos chama a atenção ${ }^{(16)}$ enfatizando a opinião de diversos autores de que a avaliação não é uma mera atividade técnica, ela incorpora aspectos filosóficos e requer compreensão do propósito da pesquisa e do significado do sucesso. Diferentes modelos metodológicos têm seus defensores e críticas, mas, para a maioria dos pesquisadores, as decisões sobre os modelos de avaliação são determinadas por dois fatores principais: as questões a serem respondidas e os problemas situacionais do processo $^{(16)}$.

Considerando o aspecto de avaliação/qualificação do material escrito, constatamos que $10(45,0 \%)$ dos pesquisadores realizavam algum tipo de avaliação e $13(59,0 \%)$ concluem a efetividade do material impresso. Quando os pacientes avaliam o material, a maioria, 4 (40,0\%) avaliaram com questionário semiestruturado e já quando aos profissionais avaliam, $1(50,0 \%)$ realizou a avaliação por meio da análise de constructo e $1(50,0 \%)$ por meio de um instrumento baseado no SAM Suitable assessment of materials, ou seja, a avaliação da adequação de materiais. O sistema SAM foi desenvolvido, pois a avaliação dos materiais é um dilema enfrentado por muitos prestadores de cuidados em saúde e porque avaliar sistematicamente a adequação dos materiais instrucionais de saúde fornecidos para os pacientes com pouco tempo disponível não é uma tarefa fácil. Os autores reconhecem que a maneira ideal é avaliar as instruções com a amostra do público pretendido, mas geralmente não há tempo e nem recursos disponíveis para isso ${ }^{(28)}$.

O desenvolvimento e validação do SAM foram conduzidos por 172 prestadores de cuidados de saúde de diversas culturas. A SAM foi originalmente projetada para ser usada com materiais escritos impressos e ilustrados, mas também tem sido aplicada com sucesso em vídeos e audiotapes instrutivos. Para cada 
material, a SAM fornece uma pontuação numérica em porcentagem que deve se encaixar em uma das três categorias: excelente, adequado e não adequado ${ }^{(28)}$.

Existe a necessidade contínua de avaliações mais abrangente. Por exemplo, pode-se esperar que, em um futuro próximo, um programa de computador será desenvolvido e irá avaliar as instruções no texto, ilustrações, áudio, TV interativa multimídia e todas essas combinações. Até que tal programa seja desenvolvido, a SAM é um passo lógico para satisfazer essa necessidade ${ }^{(28)}$.

A aplicação da SAM pode identificar deficiências específicas em um instrumento que reduzem sua adequação. Se o material ainda está em fase desenvolvimento, essas deficiências podem ser corrigidas. Se o material já está sendo utilizado, as deficiências indicam quais instruções adicionais (talvez explicações verbais) são necessárias ${ }^{(28)}$.

Os profissionais que estudam sobre os materiais parecem estar cientes sobre a necessidade de avaliar esse material já que $10(45,0 \%)$ dos pesquisadores realizavam algum tipo de avaliação contando com a colaboração do público-alvo.

É fundamental avaliar o resultado do uso dos materiais educativos para conhecer o papel que esses materiais efetivamente desempenham na comunicação entre profissionais e usuários dos serviços de saúde. Existem dois procedimentos de avaliação que podem ser considerados para o material impresso: um pré-teste aplicado durante o processo de produção, para se conhecer a percepção e interpretação das informações pelos sujeitos receptores; e uma avaliação da eficiência durante o seu uso, destinada a analisar o comportamento dos indivíduos em relação ao material ${ }^{(52)}$.

A revisão do material escrito é um procedimento para verificar a adequação do material educativo à população que irá utilizá-lo. A finalidade é descobrir as inadequações relacionadas à comunicação, bem como o design adequado e os conteúdos não abordados. Essa revisão é especialmente útil durante a fase de desenvolvimento do material, porém, para os materiais que já estão prontos, a avaliação pode revelar a necessidade de materiais didáticos suplementares ${ }^{(28)}$.

A etapa de qualificação é também um aprendizado e exige que estejamos abertos a críticas para construir algo que realmente venha a atender as expectativas e as necessidades das pessoas, as quais, certamente, possuem conhecimentos e interesses diferentes dos nossos. Faz parte dessa etapa do projeto de desenvolvimento 
a entrega do material junto a um questionário que tem por finalidade avaliar o seu conteúdo, a clareza das instruções e a sua importância como um todo. No momento da entrega do material pode ser agendada uma entrevista para que os participantes possam opinar sobre a sua percepção e realizar a avaliação crítica do documento ${ }^{(5)}$.

Ainda com relação à qualificação do manual, é importante considerar-se que, se um paciente não o entendeu, outros tantos poderão também não o entender e isso significa que o texto necessita ser modificado. Para tanto, a validação pode ser realizada em etapas, isto é, primeiro entregar o manual para duas pessoas como, por exemplo, um médico e um enfermeiro, os quais certamente vão sugerir alterações no texto; em seguida, fazer essas alterações e passá-lo, então, a mais dois participantes para fazerem as suas observações; corrigir novamente o texto e seguir entregando-o já modificado para os demais participantes do estudo. Seguindo as etapas já mencionadas, teremos um material construído com a participação de um grupo que poderá servir de apoio na orientação de pacientes e familiares ${ }^{(5)}$.

Um estudo ${ }^{(9)}$ aponta que a avaliação do material educativo, quando ocorre, raramente escapa do enfoque quantitativo e mecanicista das "escalas de atitudes e opiniões", ou oferece resultados já mais ou menos previstos, como os exemplos que os autores citam: "o público está sensibilizado...", “os pacientes agora sabem melhor", ou "aprendeu um pouquinho mais sobre a doença". Estas supostas avaliações nada esclarecem sobre as estratégias e experiências de apropriação das mensagens por parte dos usuários. Para os autores, é importante conhecer as racionalidades, motivações, lógicas de utilização e sentido das mensagens informativas/educativas, no universo do público ao qual são endereçadas ${ }^{(9)}$.

Considerando o termo empregado para nomear a avaliação dos materiais percebemos que há necessidade de ampliar o conhecimento das metodologias empregadas pelos autores, pois, dos $2(9,0 \%)$ artigos que se propuseram a validar o instrumento, apenas um validou, o outro realizou apenas uma avaliação por mero de questionário semiestruturado.

Outro estudo ${ }^{(16)}$ relata como resultado que, entre os estudos selecionados, também apenas dois apresentam uma abordagem metodológica de avaliação adequada. Nos outros estudos, os autores avaliaram informalmente o processo como bem sucedidos dados as descrições de expressão de satisfação pelo paciente e da própria enfermeira com a experiência. Mesmo aqueles que desenvolveram 
questionários e entrevistas de avaliação não foram submetidos a qualquer tipo de análise estatística ou qualitativa. Conforme afirmado pelos autores dos trabalhos estudados, houve apenas a preocupação em avaliar a aplicação imediata das aprendizagens desenvolvidas no final do programa e não em longo prazo.

Sabendo que nenhum conhecimento é estático, poderíamos propor revisões periódicas da cartilha educativa desenvolvida; mas isso não é suficiente, pois estaríamos negando a premissa da forma participativa de se trabalhar em grupos. A cartilha está adequada ao grupo que a construiu. A participação desse grupo gerou esse produto com esses assuntos; outros grupos virão e poderão gerar outros produtos ou meios. Mas se desejarem utilizar esse produto existente, as adequações na construção participativa de conhecimento pela clientela se darão no processo ${ }^{(11)}$.

Quando foi estudado se os trabalhos faziam referência a alguma abordagem pedagógica, $17(77,0 \%)$ deles não faziam referência e apenas $5(23,0 \%)$ se referiam a alguma abordagem pedagógica. Esses cinco artigos citam como referencial teórico Paulo Freire e sua Teoria da Problematização. Essa teoria, conforme expresso anteriormente, define a educação como atividade em que professores e alunos são mediatizados pela realidade que apreendem e da qual extraem o conteúdo da aprendizagem, atingem um nível de consciência dessa realidade, possibilitando a transformação social. A educação libertadora questiona a realidade das relações do homem com a natureza e com outros homens, visando a sua transformação.

Pelos resultados obtidos percebemos a terminologia não concisa entre os autores dos termos que nomeiam nos materiais escritos pode refletir o desconhecimento da diferença entre cada um desses tipos de materiais. Faz-se necessário que o autor justifique a utilização de cada recurso relacionando a adequação ao público-alvo.

Verificamos também que o enfermeiro reconhece a necessidade de informar o paciente, visto que $7(32,0 \%)$ dos artigos do nosso estudo, tinham como objetivo relatar o processo de elaboração do material escrito. Entretanto, identificamos que o tema materiais escritos impressos de orientação em Enfermagem aparece vinculado à temática educação em saúde quando encontramos que $1(5,0 \%)$ dos artigos tinha como objetivo desenvolver e avaliar ações onde o material foi utilizado como instrumento educativo e $3(14,0 \%)$ dos artigos tinham o objetivo de relatar sobre um projeto educativo onde o material é uma das estratégias de ensino. 
Ainda há questões a serem respondidas no processo de avaliação dos materiais escritos impressos no que se refere à periodicidade dessa avaliação e como avaliar materiais em setores com alta rotatividade de pacientes, considerando-se a grande variedade do público atendido. 


\section{CONCLUSÕES E CONSIDERAÇÕES FINAIS}

O presente estudo teve como analisar as características da comunicação dos materiais escritos impressos elaborados por enfermeiros brasileiros, que subsidiam as orientações em Enfermagem. Buscamos, por meio da literatura nacional, realizar uma aproximação geral do tema sem ter a pretensão de esgotar o assunto. Para investigar a contribuição de pesquisas realizadas sobre os materiais de orientação em Enfermagem, optou-se pelo método de revisão integrativa da literatura.

O levantamento bibliográfico foi realizado através da Internet, no Portal BVS (Biblioteca Virtual em Saúde) e BVS temática em Enfermagem. Para tal levantamento utilizamos 9 descritores e 7 palavras chaves. O número de artigos que atendiam os critérios de inclusão e que fizeram parte desse estudo foi de 22 .

Como resultados obtivemos na caracterização dos autores que em relação à titulação a maioria é doutor com $23(32,3 \%)$ e a profissão que mais se destacou foi a de docente com 34 (54,8\%). Do total de docentes 6 (50,0\%) lecionam em instituições na região Sudeste, das quais $7(58,0 \%)$ são federais.

Dos artigos selecionados verificamos que houve maior produção na década de 2000, ou seja, nos últimos 10 anos, representando 18 (81,8\%) dos artigos. Onze (50,0\%) foram desenvolvidos no estado de São Paulo 11, porém, ao analisarmos as publicações por cidade, a que obteve destaque foi Fortaleza com 6 (27,2\%).

Os periódicos mais citados foram Rev. Brasileira de Enf. Brasília, Rev. Eletrônica de Enf., Rev. Latino-am Enf., Revista de Pediatria e Texto e Contexto Enf com $2(9,0 \%)$ cada. O tipo de publicação predominante foi pesquisa regular com 11 $(50,0 \%)$.

Em relação aos objetivos, verificamos que 7 (32,0\%) dos artigos têm como objetivo relatar o processo de elaboração do material, já em relação aos delineamentos de pesquisa mais frequentes na amostra estudada, identificamos que 11 (50,0\%) são estudos qualitativos, 6 (27\%) são estudos quantitativos, e os estudos caracterizados como relato de experiência representam $5(22,7 \%)$ deles. 
Ao pesquisar sobre o tipo de financiamento referido, descobrimos que apenas $7(32,0 \%)$ receberam auxílio financeiro, sendo que entre as entidades financiadoras destacamos o CNPq com 4 (57,0\%) dos financiamentos referidos.

Constamos quanto às especialidades que as mais encontradas foram neonatologia e oncologia representando $4(18,0 \%)$ cada uma delas. Nota-se também que entre público-alvo - pacientes, 11 (79,0\%) deles são adultos e entre público-alvo - acompanhantes, $6(43,0 \%)$ são acompanhantes de neonatos. Quanto ao local onde o material escrito foi utilizado destacam-se os hospitais e ambulatórios, com 9 (41,0\%) cada um deles.

Em relação ao nome utilizado para o material escrito, destacamos que o mais frequente foi cartilha, com $6(27,0 \%)$. Dos artigos que apresentaram preocupação com a elaboração do material, constatou-se que o aspecto mais relevante foi conteúdo, com $12(26,0 \%)$. Pesquisamos também qual profissional apresenta-se como consultor na elaboração do material escrito e o que apresentou maior frequência foi a equipe multidisciplinar com $3(38,0 \%)$.

Quando pesquisamos de que maneira o público-alvo colabora, encontramos 3 (38,0\%) entrevistas, sendo que 2 delas são entrevistas semiestruturadas. Em relação aos trabalhos que faziam referência a alguma abordagem pedagógica, apenas 5 $(23,0 \%)$ faziam referência a alguma abordagem pedagógica, sendo que todos citam como referencial teórico Paulo Freire e a Teoria da Problematização.

Analisamos também se os artigos realizavam avaliação do material escrito. Como resultado, obtivemos que $10(45,0 \%)$ dos artigos realizavam avaliação do material escrito. Pesquisamos de que maneira essa avaliação foi realizada e dividimos em dois grupos: quando os pacientes avaliam e quando os profissionais avaliam. Quando os pacientes avaliam o material, a maioria, 4 (40,0\%) avaliaram com questionário semiestruturado. Já quando os profissionais avaliam, 1 (50,0\%) realizou a avaliação por meio da análise de constructo e $1(50,0 \%)$ por meio de um instrumento baseado no SAM - Suitable assessment of materials, ou seja, a avaliação da adequação de materiais. Analisamos também se os artigos concluíam efetividade do uso do material escrito. Como resultado, obtivemos que 13 (59,0\%) dos artigos concluíram efetividade do uso do material escrito.

E como último dado do instrumento de coleta de dados, pesquisamos se os artigos que tinham como objetivos elaborar e avaliar materiais escritos utilizavam 
referências nacionais e internacionais quanto à elaboração e validação dos materiais escritos. Constatamos que dos $14(100,0 \%), 4$ (28,7\%) citavam referências nacionais; $4(28,7 \%)$ citavam referências internacionais; e $6(42,8 \%)$ citavam outros artigos que também tinham o objetivo de elaborar e/ou validar materiais escritos de orientação.

O total de artigos publicado na BVS no período de coleta de dados foi de 20.818.978 artigos e o número de artigos encontrados nesse estudo foram 22. Acerca disso, nos questionamos se o profissional assistencial, ou seja, aquele que está no cuidado direto com o paciente, não publica trabalhos relacionados aos materiais escritos impressos de orientação em Enfermagem que produzem. Esses números demonstram que o tema materiais escritos impressos de orientação em enfermagem é pouco estudado e que a enfermagem precisa desenvolver muitas pesquisas em relação ao tema.

Os resultados obtidos levam-nos a considerar que existe uma grande variedade e pouco consenso entre os autores quanto à terminologia usada para $\mathrm{o}$ material escrito de orientação. A terminologia não concisa entre os pesquisadores tal como orientação, educação, ensino, podem levar a uma inadequada compreensão teórica e prática e dificultar a localização de artigos que retratem esse tema.

Entre os artigos encontrados, verificamos que a Enfermagem evoluiu quanto à percepção da necessidade do uso de metodologias baseadas na participação do público-alvo, mesmo que ainda de forma discreta. Identificamos também que a Enfermagem vem valorizando a necessidade de adequação do conteúdo, da linguagem, estrutura do texto, layout e figuras, voltados ao público para qual o material se destina, bem como a indispensabilidade do trabalho de equipe multidisciplinar, envolvendo não somente profissionais da área da saúde, mas também pedagogos, diagramadores, arte-finalistas, desenhistas, etc.

Os profissionais que estudam os materiais parecem estar cientes da necessidade de avaliar esse material, porém há necessidade de ampliar o conhecimento das metodologias empregadas.

Ainda há questões a serem respondidas no processo de avaliação dos materiais, no que se refere à periodicidade dessa avaliação e como avaliar materiais em setores com alta rotatividade de pacientes, considerando a grande variedade do público atendido. Entretanto, pela escassez de material na literatura nacional sobre o tema, se faz necessário buscar referências internacionais vistas à produção de novos 
conhecimentos e práticas nas quais já haja algumas definições e adaptá-las para a nossa realidade brasileira.

A necessidade de criação de novos artifícios coloca a Enfermagem como uma ciência em construção, por isso, reconhecemos a necessidade de empenho científico e conhecimento, entretanto, ainda se faz necessário encontrar alternativas e estratégias para lidar com a falta de recursos financeiros e humanos, fator que hoje é limitante de várias pesquisas no Brasil.

Consideramos o principal limite desse estudo o fato de termos trabalhado com artigos científicos e não com todo material produzido, incluindo dissertações e teses. Ressalta-se também que estudos que agreguem outros idiomas permitirão identificar as características da comunicação dos materiais escritos impresso de orientação pela Enfermagem mundial.

Esse estudo contribuiu para atenção ao fenômeno materiais escritos impressos de orientação em Enfermagem têm sido pouco estudado, mesmo pelos pesquisadores do tema comunicação em Enfermagem. Diante disso, temos a expectativa de que este estudo possa incentivar a continuidade de pesquisas na área, pois há necessidade de aprofundar o conhecimento sobre o tema, adaptar conhecimentos encontrados na literatura internacional para a realidade brasileira e buscar novos conhecimentos que otimizem a assistência de Enfermagem. 
REFERÊNCIAS 


\section{REFERÊNCIAS}

1. Padilha MICS, Mancia JR. Florence Nightingale e as irmãs de caridade: revisitando a história. Rev Bras Enferm. 2005;58(6):723-6.

2. Saupe R. Preparo do enfermeiro para ser educador: realidade e possibilidades. [homepage na Internet]. Florianópolis, 1999 [citado 2012 mar 21]. Disponível em: http://www.ccs.ufsc.br/enfermagem/educacao/livro_virtual/livrocapa2.htm.

3. Zago MMF. O papel do enfermeiro hospitalar no ensino do paciente. Rev Esc Enferm USP. 1992;26(3):359-64.

4. Rocha PK, Prado ML, Wal ML, Carraro TE. Cuidado e tecnologia: aproximações através do modelo de cuidado. Rev Bras Enferm. 2008;61(1):113-6.

5. Echer IC. Elaboração de manuais de orientação para o cuidado em saúde. Rev Lat-Am Enferm. 2005;13(5):1-5.

6. Freitas AAS, Cabral IE. O cuidado à pessoa traqueostomizada: análise de um folheto educativo. Esc Anna Nery Rev Enferm. 2008;12(1):84-9.

7. Gimeniz PSR, Pereira DM, Nascimento EN. Efeito de ação educativa sobre o conhecimento de familiares a respeito de queimaduras infantis em ambiente doméstico. Rev Lat-Am Enferm. 2009;17(3):341-6.

8. Freire P. Pedagogia da autonomia. 34a ed. São Paulo: Paz e Terra; 2006.

9. Rozemberg B, Silva APP, Vasconcellos-Silva PR. Impressos hospitalares e a dinâmica de construção de seus sentidos: o ponto de visa dos profissionais de saúde. Cad Saúde Pública. 2002;18(6):1685-94.

10. Arthur VA. Written patient information: a review of the literature. J Adv Nurs. 1995; 21(6):1081-6.

11. Fonseca LMM, Schochi CGS, Rocha SMM, Leite AM. Cartilha educativa para orientação materna sobre os cuidados com o bebê prematuro. Rev Lat-Am Enferm. 2004;12(1):65-75.

12. Bordenave JD. Alguns fatores pedagógicos. Brasília; 1994. [Apostila do curso de capacitação pedagógica para instrutor/supervisor da Área da Saúde Ministério da Saúde. Coordenação Geral de Desenvolvimento de Recursos Humanos para o SUS].

13. Antunes MJM, Shigueno LYO, Meneghin P. Métodos pedagógicos que influenciaram o planejamento das ações educativas dos enfermeiros: revisão bibliográfica. Rev Esc Enferm USP. 1999;33(2):165-74. 
14. Bodernave JD, Pereira AM. Estratégias de ensino-aprendizagem. $29^{\mathrm{a}}$ ed. Petrópolis: Vozes; 2008.

15. Freire P. Pedagogia do oprimido. 13a ed. Rio de Janeiro: Paz e Terra; 1983.

16. Melles AM, Zago MMF. Análise da educação de clientes/pacientes na literatura brasileira de enfermagem. Rev Lat-Am Enferm. 1999;7(5):85-94.

17. Pereira ALF. As tendências pedagógicas e a prática educativa nas ciências da saúde. Cad Saúde Pública. 2003;19(5):1527-34.

18. Sonobe MS, Hayashida M, Mendes IAC, Zago MMF. O método do arco no ensino pré-operatório de pacientes laringectomizados. Rev Bras Cancerol. 2001;47(4):425-33.

19. Silva MJP. Comunicação tem remédio: a comunicação nas relações interpessoais em saúde. São Paulo: Loyola; 2009.

20. Stefanelli MC. Comunicação com o paciente: teoria e ensino. $2^{\mathrm{a}}$ ed. São Paulo: Robe Editorial; 1993.

21. Littlejohn SW. Fundamentos teóricos da comunicação humana. Rio de Janeiro: Guanabara; 1988.

22. Stefanelli MC, Carvalho EC, Arantes EC. A comunicação nos diferentes contextos da enfermagem. Barueri: Manole; 2005.

23. Moreira MF, Nóbrega MML, Silva MIT. Comunicação escrita: contribuição para a elaboração de material educativo em saúde. Rev Bras Enferm. 2003;56(2):184-8.

24. Braga EM, Silva MJP. Comunicação competente: visão de enfermeiros especialistas em comunicação. Acta Paul Enferm. 2007;20(4):410-4.

25. Leão ER. Boas Práticas de Comunicação em Enfermagem. In: Viana DL, organizadora. Boas práticas de enfermagem. São Caetano do Sul: Yendis; 2010. p. 1-18.

26. Matsuda LM, Carvalho ARS, Évora YDM. Anotações/registros de enfermagem em um hospital-escola. Ciênc Cuid Saúde. 2007;6(Supl.2):337-46.

27. Coelho EOE, Emerick TO, Santos TVC. Pesquisando a comunicação escrita dos serviços de enfermagem em periódicos das bases eletrônicas de dados: um estudo sobre o estado da arte. Rev Meio Amb Saúde. 2007;2(1):112-22.

28. Doak CC, Doak, GL, Root, JH. Teaching patients with low literacy skill. Philadelphia: Lippincott; 1996. 
29. Centers for Disease Control and Prevention. Simply put: a guide creating easyto-understand materials. [guia na Internet]. 3rd ed. Atlanta, Georgia: Division of Communication Services; 2009. [citado 2012 mar. 20]. Disponível em: http://ddi.unifesp.br/media/uploads/educacao_e_pesquisa/normalizacao_de_cita cao.pdf.

30. Kleiman A. Texto e leitor. Campinas: Pontes; 1997.

31. Kato M. O aprendizado da leitura. São Paulo: Martins Fontes; 2007.

32. Assumpção MEOO, Bocchini MO. Para escrever bem. São Paulo:Manole; 2006.

33. Polit DF, Beck CT, Hungler BP. Fundamentos de pesquisa em enfermagem: métodos, avaliação e utilização. $5^{a}$ ed. Porto Alegre: Artmed; 2004. Análise quantitativa; p. 167-98.

34. Oliveira MS, Fernandes AFC, Sawada NO. Manual educativo para o autocuidado da mulher mastectomizada: um estudo de validação. Texto Contexto Enferm. 2008;17(1):115-23.

35. Souza MT, Silva MD, Carvalho R. Revisão integrativa: o que é e como fazer. Eistein. 2010;8(1):102-6.

36. Mendes KDS, Silveira RCCP, Galvão CMG. Revisão Integrativa: método de pesquisa para a incorporação de evidências na saúde e na enfermagem. Texto Contexto Enferm. 2008;17(4):758-64.

37. Galvão CM, Sawada NO, Trevizan MA. Revisão sistemática: recurso que proporciona a incorporação das evidências na prática da enfermagem. Rev LatAm Enferm. 2004;12(3):549-56.

38. Whittemore R, Knafl K. The integrative review: update methodology. J Adv Nurs. 2005;52(5):546-53.

39. Ganong LH. Integrative reviews of nursing research. Res Nurs Health. 1987;10(1):1-11.

40. Silveira RCCP. O cuidado de enfermagem e o cateter de Hickman: a busca de evidências [dissertação]. Ribeirão Preto: Escola de Enfermagem de Ribeirão Preto, Universidade de São Paulo; 2005.

41. Ursi ES. Prevenção de lesões de pele no perioperatório: revisão integrativa da literatura [dissertação]. Ribeirão Preto: Escola de Enfermagem de Ribeirão Preto, Universidade de São Paulo; 2005.

42. Santos CMC, Pimenta CAM, Nobre MRC. A estratégia PICO para a construção da pergunta de pesquisa e busca de evidências. Rev. Latino-Am. Enfermagem. 2007;15(3):508-511. 
43. Mendes IAC, Leite JL, Trevizan MA, Trezza MCSF, Santos RM. A produção tecnológica e a interface com a enfermagem. Rev Bras Enferm. 2002;55(5):55661.

44. Manual Normativo de Impressos do DIOE. [manual na Internet]. Paraná: Imprensa Oficial; 2009. [citado 2012 fev. 25]. Disponível em: http://www.imprensaoficial.pr.gov.br/arquivos/File/GRAFICA_Manual_Norma tivo_de_Impressao.pdf

45. Melnyk BM, Fineout-Overholt E. Making the case for evidence-based practice and cultivating a spirit of inquiry. In: Evidence-based practice in nursing \& healthcare. A guide to best practice. Philadelphia: Lippincott Williams \& Wilkins; 2011.

46. Flausino JM, Oliveira JZ, Zago MMFZ. Álbum seriado para o ensino do laringectomizado. Rev Lat-Am Enferm. 2000;8(1):131-3.

47. Monteiro S, Vargas E, organizadores. Educação, comunicação e tecnologia educacional: interfaces com o campo da saúde. Rio de Janeiro: Fiocruz; 2006.

48. Brasil. Ministério da Saúde. Coordenação Nacional de DST e Aids. Guia de produção e uso de materiais educativos. Brasília; 1998.

49. Costa JC, Lima RAG. Crianças/Adolescentes em quimioterapia ambulatorial: Implicações para a enfermagem. Rev Lat-Am Enferm. 2002;10(3):321-33.

50. Salles PS, Castro RCBR. Validação de material informativo a pacientes em tratamento quimioterápico e aos seus familiares. Rev Esc Enferm USP. 2010; 44(1):182-9.

51. Lopes EM, Anjos SJSB, Pinheiro AKB. Tendência das ações de educação em saúde. Rev Enferm UERJ. 2009;17(2):273-7.

52. Kubota N, Oshiro JH, Balduino MA, Faria Z de. Avaliação de material educativo: adequação de quatro volantes sobre alimentação da criança de 0 a 12 meses de idade. Rev Saúde Pública. 1980;14(1):101-22.

53. Moreira MF, Silva MIT. Readability of the educational material written for diabetic patients. Online Brazilian Journal of Nursing [serial on the Internet]. 2005 [cited 2012 March 24]; 2(4). Available from: http://www.uff.br/nepae/objn402moreiraetal.htm.

54. Torres HC, Candido NA, Alexandre LR, Pereira FL. O processo de elaboração de cartilhas para orientação do autocuidado no programa educativo em diabetes. Rev Bras Enferm. 2009;62(2):312-16.

55. Kotler P. Princípios de marketing. São Paulo: Prentice Hall; 2005. 
56. Freitas FV, Rezende Filho LA. Modelos de comunicação e uso de impressos na educação em saúde: uma pesquisa bibliográfica. Interface - Comunic. Saúde Educ. 2011;15(36):243-55.

57. Belei RA, Paschoal SRG, Nascimento EN, Matsumoto PHVR. O uso de entrevista, observação e videogravação em pesquisa qualitativa. Cadernos de Educação| FaE/PPGE/UFPel | [30]: 187-99, 2008.

58. Westphal MF, Bogus CM, Faria MM. Grupos focais: experiências precursoras em programas educativos em saúde no Brasil. Bol Oficina Sanit Panam. 1996; 120(6):472-82.

59. Bocchi SCM, Juliani CMCM, Spiri WC. Métodos qualitativos de pesquisa: uma tentativa de desmitificar a sua compreensão. Departamento de Enfermagem, Faculdade de Medicina, UNESP Botucatu; 2008.

60. Cassiani SHB. A coleta de dados nas pesquisas em enfermagem: estratégia, validade e confiabilidade [dissertação]. Ribeirão Preto: Escola de Enfermagem de Ribeirão Preto, Universidade de São Paulo; 1987. 


\section{APÊNDICE}

\section{Apêndice A - Instrumento de Coleta de Dados}

Título:

1) TRATAMENTO DE AUTORES:

\section{$1^{\circ}$ autor}

Titulação:

$\square$ discente $\quad \square$ graduado $\quad \square$ especialista $\quad \square$ mestrando $\quad \square$ doutorando
$\square$ mestre $\quad \square$ doutor $\quad \square$ pós-doutor

\section{Profissão:}

$\square$ docente:

Instituição de ensino:

enfermeiro assistencial

$\square$ hospital (setor) $\_$clínica part.
$\square$ autros
$\square$ ambulatório $\square$ UBS

$\square$ supervisor/coordenador

$\square$ não informado

$\square$ outros

\section{$2^{\circ}$ autor}

Titulação:

$\square$ discente $\quad \square$ graduado $\quad \square$ especialista $\quad \square$ mestrando $\quad \square$ doutorando
$\square$ mestre $\quad \square$ doutor $\quad \square$ pós-doutor

\section{Profissão:}

$\square$ docente:

Instituição de ensino:

$\square$ enfermeiro assistencial

$\square$ hospital (setor) $\square$ ambulatório $\square$ UBS

$\square$ clínica part.

$\square$ outros

supervisor/coordenador

não informado

outros 
$3^{\circ}$ autor

Titulação:

$\square$ discente $\square$ graduado $\square$ especialista $\square$ mestrando $\square$ doutorando

$\square$ mestre $\quad \square$ doutor $\quad \square$ pós-doutor

Profissão:

$\square$ docente:

Instituição de ensino:

$\square$ enfermeiro assistencial

$\square$ hospital (setor) $\_$ambulatório $\square$ UBS
$\square$ clínica part.
$\square$ outros

$\square$ supervisor/coordenador

$\square$ não informado

outros

2) DADOS REFERENTES À PUBLICAÇÃO:

Ano de publicação

Local do Estudo: Estado Cidade

Base de dados: $\square$ Lilacs $\square$ ScieLo $\square$ Medline $\square$ Outros:

Revista

Relacionado a:

$\square$ TCC $\square$ monografia $\quad \square$ dissertação $\square$ tese

$\square$ pesquisa regular $\square$ outro

3) DADOS REFERENTES AO ARTIGO:

Objetivo do artigo

Metodologia de pesquisa:

$\square$ qualitativa $\quad \square$ quantitativa $\quad \square$ relato de experiência 
Financiamento referido?

$\square \operatorname{sim} \square$ não Qual?

\section{4) DADOS REFERENTES AO MATERIAL ESCRITO}

A. Público alvo:

Pacientes

$\square$ crianças $\square$ adolescentes $\square$ adultos $\square$ idosos $\square$ geral $\square$ não especificado

Familiares e acompanhantes

$\square$ neonatos $\square$ crianças $\square$ adolescentes $\square$ adultos $\square$ idosos $\square$ geral

$\square$ não especificado

B. Especialidade

C. Local de uso do material

$\square$ hospital $\square$ ambulatório $\square$ UBS $\square$ clínica

$\square$ outros

D. Nome utilizado para o material escrito:

$\square$ cartilha $\quad \square$ material escrito $\quad \square$ manual $\quad \square$ impresso

$\square$ folheto $\square$ prospecto $\quad \square$ folder

$\square$ outros

E. Apresenta descrição do material?

$\square \operatorname{sim} \quad \square$ não

F- Apresenta preocupação com a elaboração do material?

$\square \operatorname{sim} \quad \square$ não $\quad \square$ não se aplica 
G- Se sim, em qual aspecto?

$\square$ linguagem $\square$ conteúdo $\square$ layout ( tipo de letra, tamanho da folha, cor)

$\square$ estrutura do texto (extensão da frase, tipo de texto)

$\square$ figuras/ilustrações

$\square$ colaboração de outro profissional

colaboração do público alvo

outros

H- Faz referência a alguma abordagem pedagógica?

$\square \operatorname{sim} \quad \square$ não $\quad$ Qual?

I- Realiza validação do instrumento?

$\square \operatorname{sim} \quad \square$ não $\quad \square$ não se aplica

Como?

J- Conclui efetividade do uso do material?

$\square$ sim $\square$ não $\square$ não se aplica

K- Utiliza referência internacional relacionada à elaboração de materiais escritos?

$\square \operatorname{sim} \square$ não 